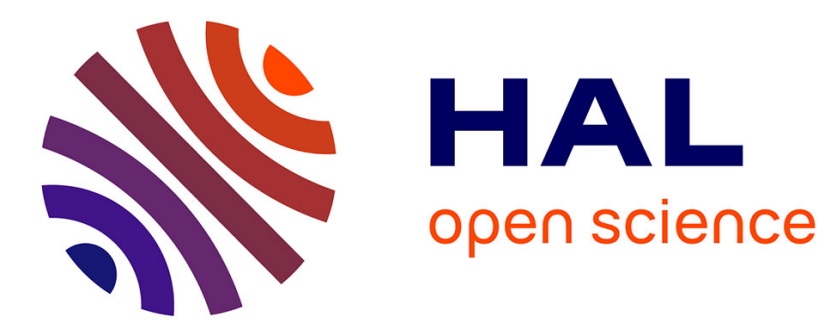

\title{
Crustal versus mantle core complexes
}

Jean-Pierre Brun, Dimitrios Sokoutis, Céline Tirel, Frédéric Gueydan, Jean van den Driessche, Marie-Odile Beslier

\section{To cite this version:}

Jean-Pierre Brun, Dimitrios Sokoutis, Céline Tirel, Frédéric Gueydan, Jean van den Driessche, et al.. Crustal versus mantle core complexes. Tectonophysics, 2018, 746, pp.22-45. 10.1016/j.tecto.2017.09.017 . insu-01610186

\section{HAL Id: insu-01610186 https://hal-insu.archives-ouvertes.fr/insu-01610186}

Submitted on 4 Oct 2017

HAL is a multi-disciplinary open access archive for the deposit and dissemination of scientific research documents, whether they are published or not. The documents may come from teaching and research institutions in France or abroad, or from public or private research centers.
L'archive ouverte pluridisciplinaire HAL, est destinée au dépôt et à la diffusion de documents scientifiques de niveau recherche, publiés ou non, émanant des établissements d'enseignement et de recherche français ou étrangers, des laboratoires publics ou privés. 


\section{Accepted Manuscript}

TEGTONOPHYSICS

mats

Crustal versus mantle core complexes

Jean-Pierre Brun, Dimitrios Sokoutis, Céline Tirel, Frédéric Gueydan, Jean Van Den Driessche, Marie-Odile Beslier

PII:

S0040-1951(17)30395-5

DOI: doi:10.1016/j.tecto.2017.09.017

Reference:

TECTO 127630

To appear in:

Tectonophysics

Received date:

31 January 2017

Revised date:

16 September 2017

Accepted date:

23 September 2017

Please cite this article as: Jean-Pierre Brun, Dimitrios Sokoutis, Céline Tirel, Frédéric Gueydan, Jean Van Den Driessche, Marie-Odile Beslier, Crustal versus mantle core complexes. The address for the corresponding author was captured as affiliation for all authors. Please check if appropriate. Tecto(2017), doi:10.1016/j.tecto.2017.09.017

This is a PDF file of an unedited manuscript that has been accepted for publication. As a service to our customers we are providing this early version of the manuscript. The manuscript will undergo copyediting, typesetting, and review of the resulting proof before it is published in its final form. Please note that during the production process errors may be discovered which could affect the content, and all legal disclaimers that apply to the journal pertain. 


\section{CRUSTAL VERSUS MANTLE CORE COMPLEXES}

Jean-Pierre Brun ${ }^{1}$, Dimitrios Sokoutis ${ }^{2,3}$, Céline Tirel $^{4}$, Frédéric Gueydan ${ }^{5}$, Jean Van Den Driessche $^{1}$ and Marie-Odile Beslier ${ }^{6}$

1. Géosciences Rennes, Unité Mixte de Recherche 6118, CNRS et Université de Rennes 1, Rennes, France

2. Utrecht University, Faculty of Geosciences, Utrecht, The Netherlands

3. University of Oslo, Department of Geosciences, Oslo, Norway

4 Dublin Institute for Advanced Studies, Geophysics Section, 5 Merrion Square, Dublin 2, Ireland

5. Géosciences Montpellier, Unité Mixte de Recherche 5243 CNRS et Université de Montpellier, Montpellier, France

6. Université Côte d'Azur, CNRS, Observatoire de la Côte d'Azur et IRD, Geoazur, Nice Sophia-Antipolis, France

\section{Abstract}

Deep crustal and mantle rocks are exhumed in core complex mode of extension in three types of structures: metamorphic core complexes, oceanic core complexes and magma poor passive margins. Using available analogue and numerical models and their comparison with natural examples, the present paper reviews the mechanical processes involved in these different types of extensional setting. Three main aspects are considered: i) the primary role of lithosphere rheology, ii) the lithosphere-scale patterns of progressive deformation that lead to the exhumation of deep metamorphic or mantle rocks and iii) the initiation and development of detachment zones. Crustal core complexes develop in continental lithospheres whose Moho temperature is higher than $750^{\circ} \mathrm{C}$ with "upper crust-dominated" strength profiles. Contrary to what is commonly believed, it is argued from analogue and numerical models that detachments that accommodate exhumation of core complexes do not initiate at the onset of extension but in the course of progressive extension when the exhuming ductile crust reaches the surface. In models, convex upward detachments result from a rolling hinge process. Mantle core complexes develop in either the oceanic lithosphere, at slow and ultra-slow spreading ridges, or in continental lithospheres, whose initial Moho temperature is lower than $750^{\circ} \mathrm{C}$, with "sub-Moho mantle-dominated" strength profiles. It is argued that the mechanism of mantle exhumation at passive margins is a nearly symmetrical necking process at 
lithosphere scale without major and permanent detachment, except if strong strain localization could occur in the lithosphere mantle. Distributed crustal extension, by upper crust faulting above a décollement along the ductile crust increases toward the rift axis up to crustal breakup. Mantle rocks exhume in the zone of crustal breakup accommodated by conjugate mantle shear zones that migrate with the rift axis, during increasing extension.

Keywords: Core complexes, wide rifts, mantle exhumation, magma poor passive margins, oceanic spreading ridges

\section{Introduction}

Metamorphic core complex (MCC) correspond to dome shaped structures inside which deep crust or mantle rocks, mylonitized at least at their top, are separated from lowergrade or non-metamorphosed rocks seated above by a shallow-dipping extensional detachment zone. The identification of MCCs and associated detachment faults as products of large-magnitude continental extension, first in the North American Cordillera (see reviews by Coney, 1980 and Armstrong, 1982) and soon afterward in most orogenic domains, from Phanerozoic (Dewey, 1988; Burg et al., 1994) to Precambrian (e.g. Neumayr et al., 1998; Cosca et al., 1995), has considerably changed our understanding of lithosphere deformation. This change has been so profound that it can be considered as a major step in our understanding of continental tectonics, as pointed out by Wernicke (2009). However, after four decades of field and geophysical studies and modeling attempts, the mechanics of core complex development and of their geodynamic settings still remain a matter of debate (see recent reviews by Whitney et al., 2013 and Platt et al., 2015).

The discovery of mantle rocks exhumed in slow and ultra-slow spreading ridges in the Atlantic and Indian oceans (see reviews by Blackman et al., 2009 and Whitney et al., 2013) in association with low angle detachment faults (Tucholke and Lin, 1994; Cann et al., 1997; Cannat et al., 2009), lead to the concept of oceanic core complexes (OCCs) by analogy with MCCs. Conversely, the exhumation of mantle rocks at the tip of passive margins, first discovered in the Galicia margin in Northwest Spain (Boillot et al., 1987; Beslier et al., 1990) and then at several other comparable sites (see review by Peron-Pinvidic et al., 2013), is seldom referred to as core complex-type process (e.g. Weinberg et al., 2007), even if, since Boillot et al. (1987), most studies invoke "low-angle detachment zones". 
Lithosphere extension processes that lead to the exhumation of deep ductile rocks, from either crust or mantle, are classically ranked into three categories of extensional structures (Fig. 1). These distinctions come from obvious differences in geological terms: location at plate boundary or intra-plate, continental versus oceanic lithosphere, crustal versus mantle nature of the exhumed rocks, deformation pattern accommodating the exhumation and resulting structure. However, a given type of mechanical instability can give birth to a variety of deformation patterns that strongly depends on the initial rheological structure of the deforming system. Folding of layered systems that results from a buckling instability provides a well-known illustration of this (e.g. Schmalholz and Mancktelow, 2016). The large variety of fold shapes is primarily controlled by the variety of geological layering (i.e. rheological contrasts between layers, relative thicknesses of layers, bulk anisotropy of layered systems...). For similar reasons, the main types of large-scale extensional structures primarily depend on the rheological layering of the lithosphere (Buck, 1991; Brun, 1999). Among these structures, those who lead to the exhumation of deep ductile rocks from either crust or mantle all result from a necking instability (Schmalholz and Mancktelow, 2016) of the brittle or high-strength layer lying above the ductile layer to be exhumed: i) the upper brittle crust for MCCs, ii) the whole crust plus the sub-Moho high strength mantle for non-volcanic passive margins and iii) an upper brittle layer of the oceanic lithosphere for OCCs. Therefore, beyond the geological differences and tectonic signatures that result from the three different types of lithosphere rheological layering, the involved process is similar. This is a necking, up to rupture, of the upper brittle or high-strength layer pile that rests on top of the exhuming ductile material. The corresponding extensional structures in the core of which the metamorphic or mantle rocks are exhumed can be simply referred as crustal or mantle core complexes.

The necking of the upper brittle layer lying above the exhuming ductile layer is dominantly accommodated by faults. However, when the core complex is formed -i.e. when metamorphic or mantle rocks are exhumed- only deformed remnants of the initial upper brittle layer remain, separated from the exhumed rocks by a detachment zone. Therefore, a fundamental question but seldom discussed is: do detachment zones initiate at the inception of upper brittle layer necking or do they develop progressively during the necking process? Most studies of MCCs and OCCs implicitly assume that the detachment zone forms at the onset of extension and drive the exhumation of deep rocks, from either crust or mantle. It is difficult to provide an answer to questions concerning the initiation of the detachment zones only from field evidence because i) a core complex represents the ultimate product of the necking 
process and ii) witnesses of the initial geometry of faulting in the upper brittle layer are either not preserved or too strongly obscured by necking-related deformation to provide reliable constraints. On the other hand, because field observations are difficult to extrapolate downward to more than $5 \mathrm{~km}$, even where reflection seismic data are available (e.g. Allmendinger et al., 1983; Gans et al., 1985; Henyey et al., 1987), the geometry of detachments at crustal scale remains poorly documented. Consequently, the initiation and development of detachment zones remains a largely open question and mechanical modeling is likely the most efficient way to test interpretations made from evidence at surface or in the shallow crust.

In the present paper, we examine the mechanical processes that lead to the extensional exhumation of deep-seated ductile rocks, from either crust or mantle. We first recall how geological and geophysical studies carried out in the Basin and Range Province of western US have led to two opposed conceptual models for the development of MCCs (i.e. "low-angle simple shear" and "rolling hinge") that resulted from and we review the modes of lithosphere extension as a function of rheology. The mechanics of crustal and mantle core complexes is then examined using results of analogue and numerical modeling and their applicability to some well-documented natural examples. Special attention is paid to: i) the primary role of lithosphere rheology, ii) the lithosphere-scale patterns of progressive deformation that lead to the exhumation of deep ductile rocks and iii) the initiation and development of detachment zones.

\section{Conceptual models of core complexes}

\subsection{The Basin and Range Province of western US: a natural laboratory}

The mechanical modeling of core complex development, using both analogue and numerical techniques, started in the late 1980ies after more than one decade of successive proposals of conceptual models deduced from field and/or geophysical studies mostly carried out in the North American Cordillera. During this period, the Basin and Range Province (BRP) of the western US became an exceptional natural laboratory where new concepts were elaborated. We highlight some of the most important steps that contributed to the understanding of core complexes. 
Following two decades of pioneer field studies at various places in the BRP (see reviews by Coney, 1980 and Armstrong, 1982), the 1977 Penrose Conference held near Tucson (Crittenden et al., 1978; 1980) has been a first important event during which the characteristics of core complexes, in terms of structure and deformation history in their relation with metamorphism, plutonism, volcanism and sedimentation, were compared and discussed. The major outcome was the recognition, in all examples considered, i) that a major low-angle detachment zone separated a low-grade brittle hanging wall from a higher-grade footwall, often characterized by high temperature metamorphism, and ii) that, whereas the hanging wall was deformed by faulting, the footwall rocks were strongly deformed and mylonitized against to the detachment zone (Coney, 1980). The earliest conceptual models of core complexes development were proposed (e.g. "megaboudinage model" of Davis and Coney, 1979; "three crustal layers model" of Rehrig and Reynolds, 1980; "Shear zone model" of Davis, 1983).

The detachment zone observed in core complexes immediately focused attention (Coney, 1980; Crittenden et al., 1980) and acquired a primary importance when it was proposed that it could correspond to the upper end of a straight normal fault dipping at lowangle and cross-cutting the whole lithosphere scale (suggested in Wernicke, 1981; fully developed in Wernicke, 1985) (Fig. 2a). This new model predicted a normal offset of the Moho whose amplitude would be comparable to the extensional displacement estimated at surface. Large displacement on such a fault results in an isostatic uplift of the footwall in response to tectonic denudation, leading to a warping and uplift of the detachment fault with the development of four structural domains: i) unextended area, ii) synformal upper plate; iii) antiformal uplift and iv) wedge-shape upper plate (Spencer 1984) (Fig. 2b). This conceptual model of normal sense simple-shear at lithosphere-scale with surface deformation distributed in distinct domains (Spencer, 1984; Wernicke, 1985) had a very strong and persistent influence on the interpretation of the regional-scale structure of many core complexes in the BRP.

Deep seismic imaging (COCORP) across the BRP brought major information for the understanding of extension at crustal scale and in particular for the extent at depth of lowangle detachment zones. Seismic profiles acquired in Nevada concluded to: i) the lack of lowangle reflections that demonstrably correspond to any low-angle normal faults, ii) the lack of evidence for significant offset of the Moho in the BRP (Allmendinger et al., 1987), and iii) that the reflection Moho in its present configuration appears to be a young feature in the BRP, 
may be related to Cenozoic magmatism and extension (Klemperer et al., 1986; Hauge et al., 1987). It was also pointed out that the well-developed Moho reflections generally correspond to a location where important Cenozoic detachments and steeper normal faults of opposite vergence focus extensional displacement deeply in the crust, likely indicating that the prominent Moho represents a basal-crust zone of decoupling for extension and westward translation of the BRP crust relative to the Colorado Plateau (Hauser et al., 1987a). The 3-km normal Moho offset found at the transition between the BRP and the Colorado Plateau in Arizona was interpreted as a late tectonic expression of crustal extension and thinning across this transition zone (Hauser et al., 1987b).

The BRP extension during the Cenozoic, with the development of core complexes, followed a period of crustal thickening in the North American Cordillera during the Mesozoic-early Cenozoic suggesting that extension could result from the lateral gravitydriven spreading of a thickened plateau-like crustal welt along the Cordilleran hinterland (Coney and Harms, 1984; Coney, 1987; Wernicke et al., 1987). Physical modeling indicated that, for such a process to occur, the Moho temperature should exceed $700^{\circ} \mathrm{C}$ (Sonder et al., 1987) and the width of thickened crust should be larger than $350 \mathrm{~km}$ (Gaudemer et al., 1988). In other terms, the crust prior to extension was thick and hot with an upper brittle crust lying on top of a thick and weak middle-lower crust. This lead to a new category of conceptual stretching models in which a brittle upper crust deforming heterogeneously by faulting is decoupled from a ductile middle-lower crust deforming in more distributed way (e.g. "Twolayer crustal stretching model" of Gans, 1987; "Fluid crustal layer model" of Wernicke, 1990).

In line with the seismic evidence and the implications of cordilleran tectonics on Cenozoic extension summarized above, the simple shear model (Figs. 2a and b) was modified assuming that a detachment dipping at low-angle in the brittle upper crust passes downward to a broader ductile shear zone with similar low dip (e.g. Fig. 4 in Davis et al., 1986; Fig.1 in Spencer and Reynolds, 1986; see also Davis and Lister, 1988) or to a distributed horizontal shear in the ductile middle-lower crust that terminates in the crust (e.g. Figs. 7 and 8 in Lister and Davis, 1989). In this type of models (Fig. 2c; after Reynolds and Lister, 1990), the upper part of the detachment still forms a syncline (compare to the "synformal upper plate" of Fig. 2b) but is connected downward to a low angle or even horizontal ductile shear zone. Note that, according to this process, the top of the footwall exhumed in the neighboring anticline (e.g. core complex) should represent the brittle-ductile transition. 
Almost simultaneously, a deformation process significantly different from previous detachment models of simple shear type (Fig. 2) was introduced on either i) a conceptual basis sustained by thin plate flexure modeling (Buck, 1988) (Fig. 3a) or ii) a conceptual model designed from field observation and measurements (Wernicke and Axen, 1988) (Fig. 3b). In this type of model, later called "rolling hinge", the detachment fault results from the sequential development of high-angle normal faults. With increasing extension and footwall isostatic rebound, each new fault is rotated to a low dip then abandoned as a new fault develops in the hanging wall. At finite amplitude of extension, a flat-lying detachment zone is created through the forward sequential development of steeply dipping normal faults (Figs. 3a and $b$ ). In Figure $3 b$ the hanging wall displaces horizontally along the brittle-ductile transition. Figure $3 \mathrm{c}$ illustrates: i) the asymmetric growth of the core complex, ii) the transition from ductile to brittle due to cooling during core rocks exhumation and iii) the progressive bulk thinning of the crust during progressive extension (after Brun and Van Den Driessche, 1994). Field tests of rolling hinge have been proposed (e.g. Axen and Bartley, 1997) but both types of conceptual models (Large-scale low-angle normal detachment (Fig. 2) and rolling hinge (Fig. 3)) have been used during a long period for the interpretation of metamorphic core complexes, feeding numerous debates. In particular, the rolling hinge model provided a mechanical explanation for the origin of low-angle detachment zones compatible with the classical "Andersonian" theory of faulting. However, the search for realistic mechanical solutions that could explain normal faulting at low-angle still continues (see reviews by Axen, 2004 and Collettini 2011). Conversely, as it will be detailed in the following, the rolling hinge process has been rapidly adopted in studies of mantle core complexes that developed at oceanic spreading ridges.

The main features that define the typical anatomy of a core complex resulting from the rolling hinge process are schematized in Figure 4. The footwall forms a broad syncline below the flat part of the detachment (process called roll-under folding in Figure 3c). However, as it will be seen later in this paper, the rotation of the footwall can be also accommodated by normal faults dipping toward the ductile core. During extension and coeval rising of the core, the ductile rocks progressively cool and cross the transient brittle-ductile transition. They become brittle and part of the footwall brittle crust (Fig.4b). The two limbs of the rising ductile core are sheared in normal sense, one of these shear zones corresponding to the deep ductile part of the detachment zone. Consequently, the rising core is affected by a domeshaped foliation pattern (Fig. 4b). The lower ductile part of the core (MG1 in Fig. 4c) is in general characterized by high temperature metamorphism and can be partially molten and can 
often involve granite bodies. During their upward displacement along the detachment zone the ductile rocks progressively cool and therefore pass from ductile to brittle (Figs. 3c and 4c). In the D1 domain (Fig.4) rocks are mylonitized and if granites emplace in this domain during the process they can be affected by C/S type fabrics (Berthé et al., 1979). Entering into the brittle field, the previous high-temperature mylonites are reworked giving cataclasites and ultra-cataclasites with a strong retrogression of the mineral parageneses (Blue domain in Fig. 4). Because only the upper part of the mylonites is in general reworked by cataclastic deformation, the flat part of the detachment can give access to the downward transition between the cataclasites and the mylonites. Finally, the upper part of the detachment zone that has never been located in the ductile field displays only brittle structures (i.e. faults, breccias, gashes...). These different types of fault rocks and their geometrical relations that characterize the detachment zones and their functioning have been first identified in the BRP and their origin understood thanks to some exceptional exposures like in southern Arizona (Davis, 1987; Davis et al., 2004).

\subsection{Extension of the core complex concept to mantle exhumation}

The extensional nature of mantle rocks exhumation was identified at slow oceanic spreading ridges (SSR) (Dick et al., 1981; see review of early works by Tucholke and Lin, 1994) and soon after at the tip of passive margins (Boillot et al., 1987), now currently called magma-poor passive margins (MPPM). Following the discovery of stretching parallel corrugations that affect low angle detachment faults (so-called megamullions; Cann et al., 1997), the core complex concept has been widely adopted to describe the exhumation of mantle rocks and gabbros at slow and ultra-slow spreading ridges (see comprehensive reviews by Blackman et al., 2009 and Whitney et al., 2013). Conversely, this concept is seldom used to describe mantle exhumation at MPPM (e.g. Weinberg et al., 2007; Rosenbaum et al., 2010). This is likely due to the extremely different initial conditions in terms of lithosphere layering, either oceanic or continental, which controls the two types of extensional setting (Fig. 1). From this point of view, it is noticeable that reviews of core complexes in which metamorphic and oceanic core complexes are compared (e.g. Whitney et al., 2013) tend to overlook mantle exhumation at MPPM. However, the processes of mantle rocks exhumation at both spreading ridges and MPPM have been considered together for their potential to interpret Tethyan ophiolites (Lagabrielle and Lemoine, 1997; Lagabrielle, 2009). In addition, it has also been found useful to examine the conditions of mantle exhumation and continental breakup at MPPM in the light of the processes identified at SSR (Cannat et al., 2009). Consequently, it 
appears to us appropriate for the purpose of the present paper to group both the MPPM and the SSR under the common label of "mantle core complexes".

\section{Modes of extension as a function of lithosphere rheology}

Patterns (or modes) of continental extension primarily depend on the rheological layering of the lithosphere (Analytical models: Buck, 1991; Analogue models: Allemand and Brun, 1991; Brun et al., 1994; Brun, 1999; Tirel et al., 2006; Numerical models: Lavier et al., 1999; 2000; Tirel et al., 2004a; 2008; Wijns et al., 2005; Gessner et al., 2007; Gueydan et al., 2008; Rey et al., 2009a; 2009b; Huet et al., 2011; Wang et al., 2015; Wu et al., 2015; Wu \& Lavier, 2016). For a general appraisal of lithosphere rheology and its effects on large-scale geodynamics see Burov (2007a; 2010; 2011).

\subsection{Narrow rifts versus wide rifts}

Using analytical models, Buck (1991) shows that the difference between "narrow rifts" and "wide rifts" primarily results from: i) crustal thickness, ii) heat flow and iii) strain rate. To illustrate how the variations of rheological layering at lithosphere-scale, as a function of basal heat flux and velocity of extension, control the development of narrow rifts and wide rift deformation patterns we here use numerical models (Gueydan et al., 2008) (Fig. 5). In these models heat flux $q_{m}=20,30$ and $50 \mathrm{~mW} / \mathrm{m}^{2}$ give, from top to base, initial Moho temperatures $\mathrm{T}_{\mathrm{M}}=356^{\circ} \mathrm{C}, 482^{\circ} \mathrm{C}$ and $753^{\circ} \mathrm{C}$, respectively. Velocity of extensional displacement applied at model boundary are V=1.0 (Figs. 5a, b and c) and $0.1 \mathrm{~cm} / \mathrm{y}$ (Figs. 5d, e and f). In all models, the crust and mantle have identical densities and rheological parameters such as wet quartz for the crust and dry olivine for mantle; for more details on physical parameters and numerical procedure see Gueydan et al., (2008). A strength profile is shown for each model (Figs. 5g and h). Four models are four-layer type with a high strength sub-Moho mantle layer (Figs. 5a, b, d and e) whereas two models are three-layer type with an entirely ductile lithospheric mantle (Figs. 5c and f). Bulk amount of extension is $40 \mathrm{~km}$ in all models. In all model sections red lines show the location of the brittle-ductile transitions, in the crust $\left(B / D_{c}\right)$ and in the lithospheric mantle $\left(B / D_{m}\right)$, and of the crust-mantle interface (Moho).

All models display conjugate patterns of normal faults in brittle layers that extend downward by shear zones in the underlying ductile layers. Three types of geometrical patterns are observed. In the first pattern (Figs. 5a and f), conjugate fault-shear zones develop through 
the brittle-ductile transitions. At the upward junction of two shear zones the upper brittle crust is affected by a graben-type structure. In a second type of pattern (Figs. 5b, d and e), the ductile crust is activated in layer-parallel shear initiating a décollement an almost undeformed sub-Moho mantle. On top of the ductile crust décollement deformation of the upper brittle crust is distributed on a width that increases with decreasing extension velocity. In other words, the décollement decouples the upper crust from the high strength sub-Moho mantle. This second type of deformation pattern, involving a ductile crust décollement above which the upper brittle crust is deformed, is comparable to magma-poor passive margin-type extension. The development of this mode of crustal extension controlled by a décollement in the ductile crust will be examined in more details in a further section. In a third pattern (Figs. $5 \mathrm{c}$ and $\mathrm{f}$ ), conjugate normal faults, defining regularly spaced grabens in the upper brittle crust, extend in shear zones in the ductile crust whereas the ductile mantle is almost homogeneously deformed. In this third pattern, in which extension of the crust is distributed and the lithospheric mantle wholly ductile, the Moho remains flat.

The series of models (Figs. 5b, d and e and Figs. 5c and f) that illustrates the deformation patterns of "narrow rift" and "wide rift" modes of Buck (1991), respectively, are primarily controlled by the presence or absence of a sub-Moho high-strength layer in the lithosphere which itself depends on the thermal state of the lithosphere. With the rheological parameters used in these models the transition between the two modes of extension occurs when the Moho temperature is around $750^{\circ} \mathrm{C}$, close to the $800^{\circ} \mathrm{C}$ in the analytical models of Buck (1991) or in the numerical models of Tirel et al. (2004a; 2008). Moho temperatures in the range $750-800^{\circ} \mathrm{C}$ provide a proxy to separate "cold" from "hot" lithospheres. From a mechanical point of view, these two categories of lithospheres whose bulk strength is either "mantle dominated" or "crust dominated" (Gueydan et al., 2008) lead, in absence of local rheological or structural heterogeneities, to either localized or distributed deformation (Brun, 1999).

\subsection{Wide rifts versus core complexes}

In the analytical models of Buck (1991), the development of core complexes is a separate mode of lithosphere extension, distinct from the wide rift mode, that requires higher geotherms with Moho temperatures up to $1200^{\circ} \mathrm{C}$. However, both analogue models (Brun et al., 1994; Brun, 1999; Tirel et al., 2006) and numerical models (Tirel et al., 2004a; 2008) show that core complexes develop in the same type of rheological layering that the wide rift 
mode, if a local heterogeneity of viscosity (Brun et al., 1994) or density (Tirel et al., 2008) is present in the ductile crust below the brittle-ductile interface (Fig. 6).

\subsection{Passive margins versus core complexes}

Numerical experiments with identical model geometry, including the presence of a local density anomaly in the ductile crust, were carried out for crustal thicknesses of 30, 45 and $60 \mathrm{~km}$ and basal heat flow values of $25,30,40$ and $50 \mathrm{~mW} / \mathrm{m}^{2}$ (Fig. 7a). They define two domains of passive margin-type and core complex-type extension, separated by a boundary corresponding to Moho temperatures $\mathrm{T}_{\mathrm{M}} \approx 800^{\circ} \mathrm{C}$ and ductile crust viscosity $\mu \approx 10^{20} \mathrm{Pas}$ (Fig. 7b) (Tirel et al., 2008). Core complex-type structures display a nearly flat Moho (M) and result from a necking of the upper brittle crust (UBC) allowing the exhumation of the ductile crust (Fig. 7b). The progressive development of one of these core complex-type models is presented in the next section. Passive margin-type structures display an arched Moho that results from a necking of the whole crust and uppermost mantle (Fig. 7b). They can ultimately lead to the exhumation of subcontinental mantle, in the so-called magma poor passive margins. Schenker et al., (2012; their Fig.2) obtained a distribution of the two patterns of extension with either flat or arched Moho comparable to the one of Figure 7. In addition, these two types of extensional patterns directly compare to the "lower crustal flow" and "upper mantle flow" compensation modes of lithosphere extension of Block and Royden (1990).

\section{Crustal core complexes}

The flat Moho at regional scale in large continental domains of distributed extension (e.g. Basin and Range: Allmendinger et al., 1987; Aegean: Tirel et al., 2004b) and the local absence of Moho offset in relation with core complex detachments (e.g. Allmendinger et al., 1987; McCarthy et al., 1991) suggested that the lower crust was weak and able to flow laterally to compensate thickness variations due to variations of upper crust stretching (Gans, 1987; Buck, 1988; Wernicke, 1990; Block and Royden, 1990; Kruse et al., 1991; McKenzie et al., 2000).

On this basis, several analogue and numerical models of core complexes use a two-layer brittle-ductile crust resting on top of a wholly ductile mantle whose viscosity contrast with the ductile crust is low to very low. A first category of these models simulates only the deformation of the brittle-ductile crust above a non-deformable flat base representing the 
Moho (e.g. Brun et al., 1994; Wijns et al., 2005; Gessner et al., 2007; Mezri et al., 2015). A second category simulates the whole lithosphere deformation (e.g. Lavier et al., 1999; 2000; Tirel et al., 2004a; 2008; Rey et al., 2009a; 2009b and 2011; Huet et al., 2011; Wang et al., 2015).

Models of core complexes presented in this section combine analogue and numerical models in which the crust is represented by only two layers: a brittle crust and a ductile crust with frictional and viscous behavior, respectively. Analogue models (Brun et al., 1994; Tirel et al., 2006) consider a rheological layering based on a postulated pre-extension thermal state but cannot take into account the effects of temperature change on rock rheology. On the other hand, they provide rather realistic patterns of fault systems that accommodate lateral variations of finite stretching in the upper brittle crust. Conversely, numerical models (Tirel et al., 2004a; 2008) in which the geometry of faulting patterns in the upper crust remains extremely simple, far from observed natural fault systems, are able to simulate: i) the complex thermo-mechanical evolution of ductile crust and mantle, ii) the variations of temperature dependent viscosities, iii) the patterns of shear zones that develop inside the ductile crust during progressive extension and the evolution of the lower crust-mantle interface (i.e. Moho) geometry.

\subsection{Analogue modeling}

The analogue models shown in Figure 8 consist in two-layer systems made of sand (brittle upper crust with a frictional angle of $30^{\circ}$ ) and silicone putty (ductile lower crust with a viscosity of $1.8 \times 10^{4}$ Pa.s) (Fig. 8a). A viscosity anomaly of $1.2 \times 10^{3}$ Pa.s is placed below the sand-silicone interface to initiate strain localization at the model center. The model base is decoupled from the rigid flat base by a film of liquid soap to avoid basal shear. As soon as model building is completed the mobile right wall is liberated and the model spreads under its own weight (Fig. 8a). Three model runs with increasing amounts of finite stretching show the progressive development of faulting in the upper brittle layer and how flow of the lower viscous layer progressively compensates the upper brittle layer thinning up to its exhumation, forming a core complex (Fig. $8 \mathrm{~b}$ to $\mathrm{d}$ ).

The structural evolution illustrated by this series of experiments is schematized in Figure 8e. It illustrates the development of conjugate steep normal faults in the upper brittle crust whose evolution results in a low angle detachment zone and exhumation of the ductile 
crust -i.e. the formation of a core complex. In all experiments extension starts with a graben, followed soon after by a normal fault to the left (Figs. 8b and e-up) delimitating an upper crustal block that rotates during increasing stretching (Figs. 8c and e-middle). Block rotation that is internally accommodated by new normal faults (Figs. 8c, d and e-down) controls strain localization along the graben border fault leading to the development of a detachment. Block rotation in the detachment footwall (called "roll-under" by Brun and Van Den Driessche, 1994; see Fig. 3c) is a rolling hinge effect that progressively accommodates the detachment dip decrease down to horizontal at the top of the exhuming ductile layer. The normal faults that formed initially with steep dips become close to horizontal, indicating rotation of more than $50^{\circ}$.

To the left side of the core complex (Fig. 8e-down) the ductile layer is stretched and thinned below the zone of normal faulting that accommodates block rotation but remains coherently attached to the brittle layer with few offsets related to the largest normal faults. In other words, it is the brittle-ductile interface that is exhumed below the detachment breakaway. In these experiments, there is no potential internal cause of asymmetry in models. Therefore, the strong asymmetry obtained can be directly related to the asymmetry of applied boundary displacement (Fig. 8a).

\subsection{Comparison with conceptual models and natural examples}

As mentioned above, these analogue models exemplify a certain type of rolling hinge process: i) all faults involved are initially steeply dipping and rotate to lower angles during increasing extension. Second, the detachment footwall undergoes a roll-under effect (Fig. 3c) accommodated by normal faults and block tilting rather than by folding of the whole upper crust (as portrayed in Fig. 3c and 4a and b).

The main difference with the conceptual model of low-angle simple shear adapted to take into account the brittle-ductile layering of the crust (Fig. 2c) concerns normal faulting observed in the detachment footwall. In the conceptual model of low-angle simple shear, the tilted blocks develop above the low angle detachment that becomes the so-called "synformal upper plate" domain (Figs. $2 b$ and c) whereas, in the analogue model, the tilted blocks affect the entire brittle upper crust (Fig. 8).

The structural patterns observed in the core complexes of the Snake Range (Gans et al., 1985 and Buckskin-Rawhide (Spencer and Reynolds, 1990) in the BRP (Figs. 9a and b) fairly 
compare to the model (Fig. 8e-down). Both examples display at first order the same bulk structure with tilted blocks controlled by normal faults dipping toward the dome core. In both cases, the top of the metamorphic core unit is explicitly (Miller et al., 1983; Gans et al., 1985) or implicitly (Spencer and Reynolds, 1990) interpreted as the brittle-ductile transition. Finally, it must be noted that the Buckskin-Rawhide detachment ends up against a strongly tilted block indicating that it was initiated as a steeply dipping normal fault.

Remark 1. Décollement versus detachment. The term "Snake Range décollement" (Fig. 9a) was introduced by Coney (1974) to describe the zone of intense deformation that separates the low-grade cover terrane from the metamorphic-plutonic core of the structure (see Fig. 2 in Coney, 1980). As already pointed out, the Snake Range décollement can be interpreted as the brittle-ductile transition exhumed by extension. The same holds for the Buckskin-Rawhide core complex (Fig. 9b). During core complex formation, as illustrated by the analogue experiments (Fig. 8), the brittle-ductile transition acts as a décollement between the brittle upper crust that deforms by faulting and the middle-lower crust whose deformation is ductile and more distributed. However, Davis and Lister (1988, p.136) claimed that "the term detachment fault has gained most common usage" overlooking that, beyond any semantic or historical considerations, the two terms décollement and detachment have not the same mechanical significance (Brun and Choukroune, 1983). In addition, the same authors strongly disputed that a detachment could represent the brittle-ductile transition (p.73-76 in Lister and Davis, 1989). Nevertheless, as clearly stated by Ramsay and Huber (1987; p. 518): "A detachment cuts across lithological boundaries whereas a décollement runs parallel to a soft or incompetent horizon". In other terms, a detachment is a fault controlled by rock friction whereas a décollement corresponds to a displacement localized within a weak layer controlled by rock viscosity (e.g. Kehle, 1970) or fluid overpressure (Hubert and Rubey, 1959). Unfortunately, this misunderstanding lead to consider the two terms as synonymous (e.g. "décollement means "detachment" in French" in Twiss and Moore, 2007).

Remark 2. About the term "detachment". In the present paper, we call "detachment" or "detachment fault" the normal fault-like structure, dominantly dipping at low angles, that separates a hanging wall (i.e. brittle crust) made of low-grade rocks from a footwall made of higher grade rocks exhumed from the middle-lower crust (i.e. previously ductile crust) (Fig. 4b). The more general term "detachment zone" embraces the footwall rock thickness affected by ductile (e.g. mylonites) and brittle (e.g. cataclasites) deformations related to displacement along the detachment (Fig. 4c). During the three last decades, the term detachment has often been used to name all sorts of normal faults whose dip is $30^{\circ}$ or less. Consequently, the term 
detachment implicitly acquired a broad meaning that could lead to misunderstandings. In particular, the only observation of a detachment, taken in this broad sense, does not necessarily imply the presence of a core complex.

\subsection{Numerical modeling}

The model shown in Figure 10 is selected from the series of models presented by Tirel et al., (2008). However, for the aims of the present paper, snapshots of strain rates have been added. The model simulates the development of a core complex in a crust with an initial thickness of $60 \mathrm{~km}$, as it can result from crustal thickening during continental collision. The study uses a fully coupled thermo-mechanical numerical code (PARAVOZ), accounting for elastic-brittle-ductile properties of constituent rocks. In the model, three marker layers are used in order to trace the evolution of the upper, middle and lower crust; the latter is also divided into two differently colored sub-layers so as to facilitate visual tracing of the developing structures (Fig. 10a). A triangular initial density-viscosity anomaly (e.g. granite body of the type and size commonly present in a thickened middle crust) is located at the base of the middle crust in order to trigger strain localization at the center of the model. With reference to natural systems in which core complexes have developed, like the Basin and Range of western United States or the Aegean domain, a horizontal displacement with a constant velocity of $1.0 \mathrm{~cm} \mathrm{a}^{-1}$ is applied to left lateral boundary of the model (Fig. 10a), the opposite boundary being fixed. More details on the modeling technique can be found in Tirel et al. (2008).

In Figures $10 \mathrm{~b}$ to e, the core complex evolution is summarized by four steps each with three cross-sections showing from top to base: i) the overall structure and the geometry of the 400 and $600^{\circ} \mathrm{C}$ isotherms, ii) the strain rate and iii) the bulk finite shear strain. Line drawings of the main deformation features (Fig. 11) observed in the model (Fig. 10) emphasize the development of localized shear zones, general flow of the ductile crust and localization of the detachment during the exhumation and cooling of the ductile crust

Two main stages, initiation and amplification, of core complex development correspond to: i) a necking of the brittle upper crust and ii) the core complex growth (Fig. 11). During the first stage, the bulk deformation pattern is rather symmetrical and becomes fully asymmetrical during the second stage. A graben first initiates in the brittle upper crust whereas deformation is homogeneously distributed in the ductile crust (Figs. 10b and 11a). 
Progressive thinning of the upper crust within the opening graben allows the ductile crust to rise and to exhume. Simultaneously, ductile strain becomes heterogeneous and localizes in two conjugate shear zones connected to the graben base (Figs. 10c and 11b). These concaveshape shear zones dip around $45^{\circ}$ in their upper part and flatten downward along the brittleductile transition below the graben shoulders. The second stage is characterized by a nearly steady-state evolution during which the exhumation of the ductile crust is accommodated by a detachment zone that corresponds to the amplification of one of the two shear zones that initiated during the first stage (Figs. 10d to e and 11c to d). Strain rates sections show that the active part of the core complex progressively migrates together with the detachment zone (Figs. 10c to e), illustrating the asymmetrical growth of the core complex. During this migration of the active part, the two shear zones that accommodate the exhumation have a rather different behavior. The shear zone dipping opposite to the detachment zone permanently migrates frontward at the same rate than the detachment zone, leaving a constantly dipping foliation in the back part of the core complex (Figs. 11c and d). The rocks deforming within detachment shear zone undergo two rotations around a horizontal axis with opposite senses at the lower and upper ends of the inclined part of the detachment zone (Fig. 11d) that can be called upper and lower rolling hinges (Compare with Fig. 4 in Platt et al., 2015). The corresponding velocity field is shown in Figure 5d of Tirel et al. (2004a).

During this steady-state growth of the core complex, the exhuming ductile crust progressively cools, passing through the $600^{\circ} \mathrm{C}$ and $400^{\circ} \mathrm{C}$ isotherms (Figs. $10 \mathrm{c}$ to e). The rocks moving up below the detachment zone are first sheared in a ductile state (i.e. mylonitisation) and then in a brittle state (i.e. cataclastic flow) (see Fig. 4) when passing the $400^{\circ} \mathrm{C}$ isotherm that would represent a proxy of the brittle-ductile transition in a crust of granitic composition.

During the initiation stage, the top of the ductile crust dome rising below the extending graben in the brittle crust is affected by a progressive ductile deformation close to pure shear (Fig. 11a and b). During the amplification stage, a detachment initiates and the rising ductile crust is strongly deformed in simple shear mode within the detachment zone and then rotated to horizontal when reaching the surface (i.e. rolling hinge effect). Consequently, a transition from pure shear at the back to simple shear moving frontward can be observed in the flatlying strongly deformed zone on top of the core complex (Figs. 11c and d).

The deformation of the lower crust passive markers first forms an upright anticline (Figs. 10b and c and 12a and b) that, during the asymmetrical growth of the core complex, progressively becomes a crustal-scale recumbent fold (Figs. 10d and e and 12c and d). The 
final recumbent anticline-syncline couple (Fig. 12d) could be misleading as its asymmetry would suggest a horizontal shear top to right - i.e. opposite to the detachment zone sense of shear- in a wholly deforming ductile crust. However, as illustrated by the sequence of structural development (Fig. 12), this large-scale couple fold formed during the asymmetrical growth of the core complex. The upper part of the fold, located above the $400^{\circ} \mathrm{C}$ isotherm (see Fig. 10), is "frozen" at the back of the exhumed ductile crust and becomes the normal limb of the anticline (Figs. 12c and d). Conversely, the lower part located below the $600^{\circ} \mathrm{C}$ isotherm remains ductile and continues to flow toward the migrating active part of the core complex becoming a recumbent syncline with an inverted limb of around $60 \mathrm{~km}$ long (Fig. 12d). This process of folding within large core complexes (in Fig. 10e the dome of exhumed ductile crust reaches $150 \mathrm{~km}$ ) opens new ways to interpret large-scale recumbent folds in the ductile crust that, up to now, are always interpreted in terms of thrusting related shear. However, this would apply only to core complexes whose width of exhumed metamorphic rocks is in the order of $100 \mathrm{~km}$ like the Southern Rhodope core complex in northern Greece (Brun and Sokoutis, 2007) or the Shakhdara migmatitic gneiss dome in Pamir (Stübner et al., 2013)

\subsection{Comparison of with other numerical models}

22 modeling studies of core complexes (3 analogue and 19 numerical) are summarized in Table 1. 12 are two-layer brittle-ductile systems representing only the continental crust or the oceanic lithosphere. 10 are brittle-ductile multilayer systems representing the continental lithosphere. In 11 models, the extensional displacements are applied at one model end (i.e. asymmetrical) and in 7 models at both models ends (i.e. symmetrical). Different types of perturbations in the initial conditions are used to localize the deformation at model centre such as: fault in the brittle crust (2), low viscosity anomaly in the ductile crust (4), local cohesion loss (2) or local higher cohesion (1) in the brittle layer, thermal anomaly in the lower crust or in the mantle and wedge shape crust. In models with no perturbation (Wijns et al., 2005; Gessner et al., 2007; Tirel et al., 2009) deformation is more distributed leading to the simultaneous development of several core complexes that can interfere during their development (Tirel et al., 2009). In addition, in 11 models a strain weakening function is used in brittle and/or ductile material. In models where a strain weakening occurs in the brittle layer the development of a single fault is favored. This large variety of model settings in one hand prevents a full one to one comparison of the results but, on the other hand, it reveals 
some important clues in the mechanical behavior of the studied systems and their implications for the development of core complexes.

One especially interesting aspect of core complexes is their asymmetry. Field studies show that most, if not all, core complexes are asymmetrical. It is therefore interesting to identify the role of the main physical parameters in determining the final asymmetry of a core complex. Modeling shows that two complementary aspects need to be considered: i) the development of a detachment that is an important part of the core complex asymmetry and ii) the growth asymmetry of the metamorphic dome (i.e. the core itself).

In models where boundary displacements are applied symmetrically (i.e. with same rate at both model ends), a finite fault offset (i.e. a detachment) develops according to the rolling hinge conceptual model (Fig. 3) for brittle layer thickness $<22 \mathrm{~km}$, and if cohesion decreases with strain (reducing to zero after a 1km offset) (Lavier et al., 1999; 2000). Taking into account the hydrothermal cooling associated to faulting, large fault offsets develop in model lithospheres with brittle layers of order $10 \mathrm{~km}$ thick (Lavier and Buck, 2002). In models that include a partial melting component in the ductile layer (i.e. with lower density and a much lower viscosity than the surrounding ductile crust) a point-like anomaly in the brittle crust results in two conjugate detachment faults that connect downward at the brittleductile transition whereas a fault-like anomaly in the brittle crust results in a rolling hinge type detachment and the exhumed metamorphic dome is symmetrical in the former and asymmetrical in the later (see Fig. 3 in Rey et al., 2009). In models that integrate phase transitions controlled by pressure, temperature and the local amount of free fluid that comes from both external (meteoric) and local (dehydration) sources (Mezri et al., 2015) show a strong positive feedback between the asymmetry of the tectonic structures and the depth of penetration of meteoric fluids. From a general point of view, it must be noted that all models involving some type of strain softening favor asymmetric strain localization and the development of a rolling hinge type detachment, even in models where displacements are applied symmetrically and whatever the type of localizing perturbation (Lavier et al., 1999; 2000; Lavier and Buck, 2002; Wijns et al., 2005; Gessner et al., 2007; Rey et al., 2009a; 2009b; Tirel et al., 2009; Mezri et al., 2015; Schenker et al., 2012; Wang et al., 2015; Wu et al., 2015; Wu and Lavier, 2015). This suggests that strain softening could play a dominant role in the development of detachments and therefore in the evolution of core complex models. However, it must be recalled that the parameters of strain softening are difficult to scale on a quantitative basis with reference to natural systems and that, consequently, they are chosen on 
arbitrary bases. Consequently, more work on natural systems complemented by laboratory experiments would be necessary to produce realistic laws of strain softening that could be successfully implemented in numerical models. In models using a pre-existing fault as an upper crust perturbation to localize deformation (Skelton and Koyi, 2001; Rey et al., 2009a; $2009 b$ ), the dip of the detachment and therefore the asymmetry of the core complex are determined by the dip of the pre-existing fault. The difficulty inherent to such initial condition is to justify how and why a solitary normal fault would be created in the upper crust prior to core complex development.

In our models where boundary displacements are applied asymmetrically (i.e. at only one end of the model) and in which the localizing perturbation is a viscosity anomaly in the ductile layer and not a fault in the brittle layer, the system first evolves symmetrically and becomes asymmetrical with the development of a detachment when the top of the initially ductile crust has reached the surface -i.e. when the metamorphic crust started to exhume (Figs. $10 \mathrm{c}$ and $11 \mathrm{~b})$. In these models extension generates a finite amplitude necking instability in the brittle layer at the center of the model. The core complex first exhumes in a symmetrical way (Figs. 11a and b) creating a central weak zone that "separates" the model in two parts. Consequently, the model becomes able to react to the asymmetry in boundary displacements. A detachment zone initiates on the dome flank facing to the moving boundary and the core complex growth becomes asymmetrical (Figs. 11c and d).

It must be noted that something comparable also occurs in the analogue model described in the previous section (Fig. 8). The graben that forms at the early stages of stretching (Fig. 8b) become a weak zone that separates the upper brittle layer in two parts, making it able to react to the asymmetry in boundary displacements. In other words, the sense of dip of the detachment and the asymmetry of the core complex result from the dynamics of the whole extending system and not from the dip of a pre-existing fault in the brittle layer like in several other models. In addition, as no strain softening is included in the model set up, the rolling hinge style of the core complex cannot be attributed to this type of effect. This strongly suggests that the core complex asymmetry primarily depends on the asymmetry of applied displacement.

In most models that provide information relative to the internal deformation of the ductile layer the rise of deeper ductile units forms symmetrical or nearly symmetrical domes, even if the deformation of the brittle crust and upper part of the ductile layers is localized by a pre-existing fault (e.g. Koyi and Skelton, 2001; Tirel et al., 2004; 2008; Gessner et al., 2007; Rey et al., 2009b; Huet et al., 2011; Mezri et al., 2015; Wang et al., 2015). However, because 
this symmetrical ascent of deep unit remains located close to the dipping part of the detachment during increasing extension (see strain rate sections in Fig. 10), the growth of the exhumed core necessarily becomes asymmetrical if extension is maintained long enough (Fig. 11).

\subsection{Application to natural examples}

The model described and illustrated in Figures 10 and 11 and the comparison with other models have several implications for the study of natural examples of core complexes.

(1) The initiation of core complexes and associated detachments remains a rather disputable aspect because the early stages of extension leading to a detachment are either not conserved, due to erosion or hidden by later sedimentation, or obscured by superposed deformations during further stages of development. Most field or geophysical studies postulate, most often implicitly, that deformation of the upper crust starts with a single normal fault dipping at either low or steep angles. It must be emphasized that no mechanical model, analogue or numerical, has succeeded reproducing the initiation of a core complex with a low-angle normal fault in the upper brittle crust. In other words, the extremely successful simple shear model, more than 30 years after its introduction and in spite of successive improvements (Fig. 2), has not been verified by any laboratory or numerical experiment. In the other hand, several analogue and numerical models either postulate that a single steeply dipping normal fault pre-exists in the brittle layer or use a strain weakening function that favors the development of a single fault (Tab. 1). This single normal fault becomes the detachment with increasing extension. However, there is no available field example that could unequivocally sustain such hypotheses. Conversely, the analogue (Fig. 8) and numerical (Fig.10) experiments presented above show that brittle-ductile systems submitted to localized stretching starts with a graben (i.e. a system of conjugate normal faults) whose progressive opening controls the exhumation of the ductile crust and the initiation of a detachment. In these experiments, the detachment does not precede and, therefore, does not control the core complex development. It is, on the contrary, a product of the ongoing extension. Deformation starts with a graben that through a number of faults (Fig. 8) controls the initiation stage of the core complex (Figs. 11a and b). It is only during the amplification stage (Fig. 11c and d) that a detachment develops.

The active Corinth Rift (South Aegean domain) is an interesting natural example to be 
examined under this light. The section from the western part of the Corinth Gulf (Fig. 13) that is documented by seismic data in its offshore part (Taylor et al., 2011) and seismicity (Rigo et al., 1996) shows an asymmetric graben, defined by two series of high-angle normal faults, dipping at steeper angles to the North than to the South. The graben sedimentary fill is asymmetrical with its deeper depocenter located to the South. The oldest rift-related sediments onshore are dated around 3.6 Ma (Rohais et al., 2008). Maximum concentration of seismicity and available focal mechanisms roughly defines a band slightly dipping northward whose shallower part is located below the graben depocenter at a 7-9 $\mathrm{km}$ depth. This seismicity alignment has been interpreted as a low-angle detachment dipping northward (Rigo et al., 1996). Other interpretations of a northward dipping detachment of regional-scale extend have later been proposed (e.g. Sorel, 2000; Le Pourhiet et al., 2004; Flotté et al., 2005; Skourtos and Kranis, 2009; Jolivet et al., 2010). However, this seismicity concentration can primarily be regarded as the zone of maximum brittle strength, not far above the brittleductile transition. As suggested in Figure 13: i) the clusters of seismicity as well as the nodal planes of the focal mechanisms located in this zone appear related to the steeply dipping normal faults that directly control the graben asymmetry and ii) the shallower depth of the seismicity zone located beneath the graben depocenter likely results from the uplift of the brittle-ductile transition in the zone of maximum upper crust stretching (Compare with the analogue (Figs. 8b and c) and numerical (Fig. 11a) models). Chery (2001) proposed a mechanical analysis of faulting in the Gulf of Corinth in which steep angle faults of the upper crust are connected downward to a "décollement" that corresponds to the brittle-ductile transition, along the $350^{\circ} \mathrm{C}$ isotherm. On this basis, he suggested that, in a second stage, the décollement is uplifted allowing the exhumation of a core complex such as the northern Snake Range (Fig.9a). A depth range of 8-10km, comparable to what is observed in the Corinth rift, has been estimated for the brittle-ductile transition of the Neogene Mygdonian Graben, in the North Aegean (Kydonakis et al., 2015b), using the relation between the initial graben width and brittle-ductile transition depth (Allemand and Brun, 1991). It is important to note that at a larger scale the Gulf of Corinth is located in a continental crust that has been delaminated from a still downgoing slab (see location in Figs.14 a and b). Due to delamination, an asthenosphere wedge has penetrated in between the crust and the slab and consequently the crust has been strongly heated, providing a direct explanation for a rather shallow brittleductile transition below the Corinth rift. As the Moho depth in this area is around $40 \mathrm{~km}$, a brittle-ductile transition at around $10 \mathrm{~km}$ depth implies that the ductile crust is around $30 \mathrm{~km}$ thick giving extremely favorable conditions for core complex development, as discussed in 
section 3. In summary, the available data suggest that the Corinth Rift likely represents the initiation of a future core complex.

Gneiss domes of Papua New Guinea and Tibet rifts are two other examples that deserve being mentioned to support that detachments can originate from strongly extending graben-type structures. In Papua New Guinea, the gneiss domes of Goodenough, Mailolo and NW Normandby in the D'Entrecasteaux Islands are core complexes (Martinez et al., 2001) whose structure is nearly symmetrical and that recently exhumed within a continental rift (Little et al., 2011) ahead of the Woodlark spreading ridge. The conjugate pattern of steep normal faults that define this continental rift are mapped at the two ends of the D’Entrecasteaux Islands (see seismic sections Figs. 6, 8 and 9 and map Fig. 14 in Fitz and Mann, 2013). In Tibet, the mid-Tertiary normal fault systems trending roughly NS (Armijo et al., 1986) result from an EW-trending extension whose intensity increases eastward leading to the development of detachments. From recent detailed field studies, Kapp et al., (2008) suggest that "Tibetan rifts initiate as high-angle normal fault and half-graben or graben basin systems and evolve in response to increasing extension and footwall isostatic rebound into detachment systems that are active at uppermost crustal levels and above which rift basin fill is being uplifted and eroded ». The above-mentioned examples sustain that, like in the models shown above (Figs. 8, 10 and 11), core complexes ascent and start to exhume within opening grabens.

(2) Early pure shear at the top of the ductile crust. Numerical models show that the top of the ductile crust, which first exhume inside the extending brittle crust graben (Figs.11a and b), undergoes a pure shear deformation. During the following amplification stage of core complex growth, the top of the exhuming ductile crust is strongly deformed in simple shear (Figs. 11c and d). This predicts that a frontward transition from pure shear to simple shear could be observed in the flat-lying detachment on top of the core complex. Several early field studies in the BRP have identified evidence of pure shear deformation in the ductile fabrics of core complexes (Raft River Mountains: Compton, 1980; Ruby Mountain: Snoke, 1980; South Mountains: Reynolds and Rehrig, 1980; Black Pine Mountains: Wells and Allmendinger, 1990). A systematic c-axis quartz fabric study carried out in the direction of stretching along the Snake Range décollement (Lee et al 1987) (See section in Fig. 9a) shows: i) a spatial transition from coaxial fabrics (i.e. pure shear) to the West to non-coaxial fabrics (i.e. strong component of shearing top-to-East but not necessarily simple shear) to the East with ii) a progressive overprinting of coaxial fabrics by non-coaxial fabrics in the western part of the 
Snake Range décollement. This is in agreement with the model prediction mentioned above. It strongly supports i) that the early deformation recorded at the top of the ductile crust has likely been related to a symmetrical pattern of faulting (e.g. graben type) in the upper brittle crust (Initiation stage in Fig. 11) and ii) that the detachment, characterized by a strong top-toEast shear component (Eastern part of the section in Fig. 9), was not active since the onset of ductile deformation and that it took place in the course of core complex development (amplification stage in Fig. 11). This interpretation also partly meets the scenario proposed by Cooper et al., (2010; their Fig. 16) for the Snake Range core complex.

(3) Core complexes in their geodynamic setting. In Eastern Mediterranean, the Aegean backarc extension driven by slab rollback (Wortel and Spakman, 2000; Faccenna et al., 2003; 2014) provides a time and space frame to interpret core complex development in a rather well understood geodynamic setting. Extension started around since $45 \mathrm{Ma}$ (Brun and Sokoutis, 2010; Burg, 2011) controlled by $600 \mathrm{Km}$ of trench retreat (Jolivet and Brun, 2010). This extension occurred in two main stages: i) during the first $30 \mathrm{Ma}$ at a low rate of trench retreat $(0.6 \mathrm{~cm} / \mathrm{y})$ localized extension in a NS direction lead to the coeval exhumation of hightemperature (i.e. core complexes) and high-pressure metamorphic rocks and ii) since around $15 \mathrm{Ma}$, due to an acceleration of trench retreat (up to $3.2 \mathrm{~cm} / \mathrm{y}$ ), the whole Aegean domain undergoes distributed SW-oriented extension (i.e. wide rifting) controlling the deposition of Neogene sedimentary basins (Brun et al., 2016). The Aegean domain (Fig. 14a) is made of three continental units (Rhodopia, Pelagonia, and Adria) separated by two suture zones corresponding to the closure of small oceanic domains (Pindos and Vardar). Prior to the onset of extension, the three continental units were piled up in a thick thrust wedge by the successive subduction below Rhodopia of the Pelagonia and Adria blocks (Eocene in Fig. 14b). At the end of continental blocks subduction, the entrance of the Mediterranean oceanic lithosphere into the subduction zone delaminated the thrust wedge from the Hellenic slab (Fig. 14b) allowing southward slab rollback to start (Brun and Faccenna, 2008; Tirel et al., 2013). This shear delamination permitted the asthenosphere to progressively flow in the opening wedge between the crustal units and the slab. The Moho was therefore submitted to an asthenosphere temperature of $1300^{\circ} \mathrm{C}$ and the crust underwent a fast and strong heating from below responsible for high temperature metamorphism with partial melting and an overall thermal softening. The thrust wedge was submitted to extension in Middle Eocene at a very low boundary displacement rate $(0.6 \mathrm{~cm} / \mathrm{y})$ favoring localized deformation and the simultaneous initiation of the Northern and Southern Rhodope Core Complexes (Fig. 14c), at 
the back of the extending wedge (NRCC made of four domes and SRCC in Fig. 14a and b) (Kydonakis et al., 2015a). Exhumation stopped in late Eocene in the NRCC and continued in the SRCC up to the end of early Miocene whose exhumed core reached a width of more than $100 \mathrm{Km}$ in its southeastern part (Fig. 14a). To the South of the Rhodope core complexes, the high-pressure metamorphic units of Adria reached a crustal level (Lower Miocene in Fig. 14b). From late Oligocene to early Miocene, high-temperature metamorphism and partial melting affected the high-pressure metamorphic rocks and the Central Cyclades Metamorphic Core Complex developed (CCCC in Figs. $14 \mathrm{a}$ and b). In middle Miocene, around $15 \mathrm{Ma}$ as a mean, extension passed from a core complex mode to a wide rift mode at whole Aegean scale controlling the deposition of Neogene basins over around $1000 \mathrm{Km}$ from Rhodope to Crete. Core complexes were segmented by strike-slip faults and steep normal faults in both Rhodope (Brun and Sokoutis, 2007) and Cyclades (Philippon et al., 2012). Long grabens developed in the previously non-extended continental units to the west of the Cyclades, one of them being the Corinth rift (see location in Figs. 14a and b) (see section 4.5(1) above). Fault pattern and seismological data (Fig. 13) suggest that the Corinth rift could correspond to the initiation of a new core complex. In summary, the Aegean backarc extension illustrates that, from a mechanical point of view, core complexes develop: i) in thermally weakened crust (in this case due to crust-mantle delamination), ii) at low strain rate (boundary velocity of $0.6 \mathrm{~cm} / \mathrm{y}$ ) and iii) according to a southward sequence (1-Rhodope, 2-Cyclades, 3-Corinth) controlled by the asymmetric boundary displacement (i.e. trench retreat).

\section{Mantle core complexes}

\subsection{At oceanic ridges}

In contrast to the traditional view of mid-ocean ridges as primarily volcanic systems, seafloor spreading at slow (rates of 5.5-2.0 cm/y) and ultra-slow (rate $<2.0 \mathrm{~cm} / \mathrm{y}$ ) rates can be dominantly accommodated by tectonic process and the formation of oceanic core complexes (OCC). OCCs correspond to massifs constituted by mafic plutons and/or ultramafic mantle rocks that exhume at the seafloor in the footwall of low-angle detachments. Close to seafloor detachment zones, as imaged by reflection seismics, have a gentle convex upward profile (Ranero and Reston, 1999; Canales et al., 2004) (Fig. 15a). The microseismicity (e.g. de Martin et al., 2007) indicates that detachment faults become steeper at depth, down to the 
brittle-ductile transition or magma chambers (Tucholke et al., 1998). The upper flat part of detachments often forms dome-like structures with prominent striations parallel to the displacement direction at various wavelengths up to kilometer (e.g. Cann et al., 1997; MacLeod et al., 2002). Deformation of footwall rocks in the detachment zone is localized within a narrow shear zone $(<200 \mathrm{~m})$ with fluid flow forming talc and amphibole schists after an ultramafic protolith that may localize deformation during long periods of time (Escartin et al., 2003). Paleomagnetic measurements documented footwall rotations around a horizontal axis in the range $45^{\circ}-50^{\circ}$ (Garcès and Gee, 2007; Morris et al., 2009). The space created by footwall rotation is accommodated by addition of magmas (gabbros) at the root of detachment and/or flow of the ductile mantle (Whitney et al., 2013), comparable to the ductile crust flow in metamorphic core complexes (Fig. 11). The above observations argue in favor of mantle exhumation controlled by convex upward detachment faults, at both slow and ultra-slow spreading ridges. Numerical modeling was used to show that normal faults originate at high angle and, as fault offset increases, their footwall are rotated flexurally to an inactive lowangle configuration leading to an overall fault geometry very similar to the one observed in oceanic core complexes (Lavier et al., 1999; 2000). On the bases of observation and modeling, rolling hinge has been widely accepted for the development of oceanic mantle core complexes.

At slow spreading ridges, like the Mid Atlantic Ridge (MAR) (rate about $2.5 \mathrm{~cm} / \mathrm{y}$ ), mantle core complexes occur over $50 \%$ of the ridge length. They are located on one side of the ridge axis, dominantly composed of mafic plutons and ultramafic mantle rocks whereas the other side is volcanic (Canales et al., 2004) (e.g. Fig. 15a). In addition, the hanging wall of detachment most often corresponds to a seafloor depression controlled by a conjugate pattern of steep normal faults defining a graben-type structure (e.g. Canales et al., 2004; Escartin et al., 2008). At ultra-slow spreading ridges, like the Southwest Indian Ridge (SWIR) (rate about $1.4 \mathrm{~cm} / \mathrm{y}$ ), both sides of the ridge axis are dominantly exhumed ultramafic mantle rocks with little or no axial volcanism (Dick et al., 2003; Cannat et al., 2006). Along the SWIR, faulting accommodates almost $100 \%$ of plate divergence and the resulting seafloor is smooth on both sides of the ridge axis, likely composed of altered mantle-derived rocks (Sauter et al., 2013). Detailed mapping shows that detachment faults have repeatedly flipped polarity leading to complex final structural patterns (Fig. 15b) and volcanic patches that emplaced along highangle normal faults or dykes can be tilted by later detachment faults. The striking structuralpetrological difference between slow and ultra-slow spreading ridges suggests that the rate of extension plays an important role in core complex development at spreading ridges. 


\subsection{At passive margins}

Passive margins result from the stretching of the continental lithosphere (i.e. rifting) up to crustal breakup and building of the oceanic lithosphere. They are characterized by a thinning of the continental crust increasing oceanward whose width can reach few $100 \mathrm{~km}$. Normal faulting of the upper crust often gives tilted blocks whose size decreases oceanward. In volcanic passive margins, continental rifting is accompanied by mantle partial melting leading to magma intrusion in the lower crust, dykes and sills in the upper crust and surface lava flows. Non-volcanic (or magma-poor) passive margins contain only limited amounts of intrusive and extrusive rocks.

Soon after its application to the development of metamorphic core complexes, the conceptual model of detachment cutting through the entire lithosphere (Fig. 2a) was tentatively applied to the formation of passive margins with complementary asymmetry after continental breakup (Lister et al., 1986). The discovery of mantle exhumation at the tip of the Galicia passive margin was interpreted in the same way (Boillot et al., 1987; 1989). Consequently, considerable geological and geophysics efforts were produced for the study of the processes involved in the formation of this type of passive margins. New terminologies like "hyper-extended passive margin" or "magma-poor passive margin" were introduced but, rather surprisingly, it has seldom been referred to mantle core complex extension (among exceptions are: Weinberg et al., 2007; Rosenbaum et al., 2010). In addition, it has been suggested that mantle exhumation processes occurring at passive margins could be analogous to mantle core complex at ultra-slow spreading ridges (Cannat et al., 2006; 2009). In the frame of the present paper, dedicated to core complexes modes of deep rocks exhumation, we focus on the deformation mechanisms that, at continental lithosphere-scale, lead to mantle exhumation. Special attention is paid to the symmetry versus asymmetry of extension at lithosphere scale and to the role of ductile crust as a decoupling level between the brittle crust and the sub-Moho mantle. It is beyond our scope to review here the enormous literature that concerns, near or far, geological and geophysical studies of passive margins whose formation leads to mantle exhumation (see recent reviews: Watts, (2012) for margin evolution in general; Peron-Pinvidic et al., (2013) for Atlantic margins).

At a first order, mechanical models proposed to explain mantle exhumation at passive margins belong to two broad categories: symmetrical versus asymmetrical (Tab. 2). Most 
lithosphere models referred in Table 2 involve: i) a high strength sub-Moho layer resulting, in numerical models, from an initial Moho temperature in the range $450-550^{\circ} \mathrm{C}$, ii) ductile middle and lower crust sometimes with a lower crust stronger than the middle crust and iii) displacements applied symmetrically at both lateral model ends. Some models give a special attention to particular deformation parameters (see Tab. 2). The main outcomes can be summarized as follows.

(1) Symmetry versus asymmetry. In absence of a ductile crust (Huismans and Beaumont, 2007) and with strain softening in brittle layers, normal faults penetrate down to the base of the high strength mantle giving fault patterns conjugate and symmetrical at high rate of extension $(10 \mathrm{~cm} / \mathrm{y})$ and strongly asymmetrical at low to very low rates of extension $(0.3$ and $0.06 \mathrm{~cm} / \mathrm{y})$. In four-layer-type models the overall deformation pattern is strongly or fully asymmetrical when the deformation of brittle layers (upper crust and sub-Moho mantle) involves crustal thickness variations (Harry and Grandel, 2007), strain softening (Brune et al., 2014; 2017) or structural softening of the crust and sub-Moho mantle (Duretz et al., 2016). In absence of one of these factors, the overall deformation pattern is symmetrical in both analogue (Brun and Beslier, 1996, Nestola et al., 2013; 2014) and numerical (Nagel and Buck, 2004; 2007; Lavier and Manatchal, 2006; Burov, 2007b; Weinberg et al., 2007; Beaumont and Ings, 2012) models.

\section{(2) Ductile crust décollement.}

Nearly all models referred in Tab. 2 involve a ductile crust that is activated in layerparallel shear (i.e. décollement) during extension (see Remark 1. Décollement versus detachment in section 4.2). Two exceptions are Huismans and Beaumont (2007) where there is no potential zone of décollement in the crust and Duretz et al. (2016) where the whole crust and the upper part of lithospheric mantle are made of a kilometer-scale alternation of high strength (frictional down to $50 \mathrm{~km}$ and viscous below) and extremely weak layers (i.e. strong mechanical anisotropy at lithosphere scale). The presence or absence of a ductile layer in middle-lower crust depends on Moho temperature and rate of extension (Fig. 5). The ductile crust décollement strongly decouples the upper crust from the sub-Moho mantle. Extension is localized in the sub-Moho mantle and distributed in the upper crust. In models, whose bulk deformation pattern is asymmetrical, the décollement is connected to a detachment that cuts downward the sub-Moho mantle giving a ramp-flat geometry at lithosphere scale (Brune et al., 2014; Duretz et al., 2016). 
The role of décollement played the ductile crust, between the upper brittle crust and the high-strength sub-Moho mantle, is well illustrated in the formation of passive margins. Without a décollement in the ductile crust the series of tilted blocks that are observed at most passive margins would not have developed. Therefore, layer-parallel shear in the ductile crust cannot be treated as a detachment in its classical sense. In addition, because the width of the upper crust of passive margin showing tilted blocks is commonly up to order of $100 \mathrm{~km}$, passive margins are often considered to result from wide rifting whereas the necking zone in the sub-Moho mantle is a localized deformation. In fact, passive margins must be considered as narrow rifting whose upper part is larger than usual due to the presence of the ductile crust décollement.

(3) Analogue modeling of mantle exhumation at passive margin. Like the analogue models of core complexes discussed in section 4.1, models of passive margin (Brun and Beslier, 1996) (Fig. 16) are built with sand to represent brittle layers and silicone putties to represent ductile layers. Densities of brittle and ductile layers, viscosities of ductile layers and velocity of displacements are chosen such as the strength profile in the model is homologous to the one that characterize a natural system. Displacement is applied at constant rate at the middle of model laterally sides (i.e. in other terms, half the model, which floats on a fluid representing the asthenosphere, is pulled like a drawer by its lateral sides). Consequently, the displacements are applied asymmetrically. For more details on the modeling techniques and method of model scaling the reader can refer to Brun (1999). Figure 16a represent a model in which extension was stopped when crustal thinning at model center indicated that separation of the two continental margins was reached. In Figure 16b the bulk stretching was lower allowing: i) the analysis of the deformation pattern in both brittle and ductile layers, prior to the extremely deformed stage of margin separation, and ii) the restoration of previous stages of deformation up to initiation (Fig. 16c), using also photographs of model surface taken at regular time intervals during the experiment. Vertical passive markers in the ductile layers permitted the mapping of shear senses in the ductile layers in both crust and mantle (Fig. 16b). The main deformation features are as follows:

1. The deformation of the upper brittle crust $(\mathrm{Bc})$ displays a certain degree of asymmetry between the two sides of the rift in both sections.

2. The ductile crust (Dc) is strongly thinned and even locally entirely disappears below tilted blocks (Fig. 16a). 
3. The ductile crust acts as a décollement between the brittle upper crust (Mc) and the high-strength mantle $(\mathrm{Bm})$. The bulk thinning of the crust $(\mathrm{Bc}+\mathrm{Dc})$ increases toward the rift axis.

4. The high strength sub-Moho layer (Bm) undergoes a multiple necking with stretching localizing in one of the necking zones. Note that localization is located either to the right (Fig. 16a) or to the left (Fig. 16b) of the rift axis.

5. The lithosphere base is uplifted below the zone of strongest extension with a nearly symmetrical bell shape.

6. The passive markers in the ductile crust (Dc) and lithospheric mantle (Fig. 16b) define two conjugate shear zones (lower panel in Fig. 16c) whose senses of shear are top to left in orange and top to right in blue. These two shear zones can be directly compared to those observed in Figures $5 b, d$ and e. The restoration of the section (Fig. 16c) shows that at the onset of extension (upper panel) the deformation of the upper crust and sub-Moho mantle are decoupled by the ductile crust. With increasing extension (middle panel) the two conjugate shear zones start to localize by connection of the two upper crust grabens and the zone of necking localization in the sub-Moho mantle.

7. The internal structure of models displays a moderate asymmetry whereas the bulk thinning pattern of the whole models is close to symmetrical. The internal asymmetry is variable at once in the mantle (point 3 above) and in the crust (points2 and 3 above) whereas all experimental conditions are similar. However, the asymmetry of faulting in the upper crust is similar and in agreement with the asymmetry of applied displacements.

(4) General model for mantle exhumation at passive margins. From the experiments presented above (Fig. 16), a general model is derived to describe the processes involved in the exhumation of mantle at passive margins and their evolution in time and space (Fig. 17). Two main stages can be considered similar to those proposed for the crustal core complexes (Fig. 11). First is the "initiation" that, from a mechanical point of view, corresponds to the necking of the high strength unit (i.e. the whole crust plus the high-strength sub-Moho mantle) (Figs. $17 \mathrm{a}$ to $\mathrm{c}$ ). This stage ends with the onset of mantle exhumation. Second is the "amplification" during which extension is permanently accommodated by mantle exhumation (Figs. 17d and e). During the initiation stage, the décollement along the ductile crust plays a major role as it decouples the deformation distributed in the brittle crust from the one localized in the high strength mantle. Senses of shear in the décollement are top to the rift axis in the ductile crust 
and away from the rift axis in the ductile mantle (Figs. 17b and c). A certain degree of asymmetry can develop between the two margins in formation, in terms of both margin width and margin structure. During the initiation phase, deformation progressively localizes toward the rift axis in the crust. During this localization process, the ductile crust strongly thins and can even disappear bringing the blocks of upper crust in direct contact with the mantle. Before the end of this process, marked by the exhumation of the mantle, the thinning crust can be strongly heated by the rising mantle, even reaching partial melting. In the zone of necking a new Moho can form as the ductile mantle rising along the base of the high strength mantle arrives in contact with the strongly extended crust and becomes brittle by cooling. This implies that the shear zones, that accommodate the ascent of ductile mantle, progressively migrate toward the rift axis, as illustrated by the numerical models of Nagel and Buck, (2004; 2007). In other terms, contrary to models of fully asymmetrical rifting controlled by structural or strain softening (e.g. Brune et al., 2016; Duretz et al., 2016), there is not a single and permanent detachment fault that, after separation of the two continental crusts, would accommodate extension in the lithospheric mantle along the whole rifting process. At the beginning of the amplification stage, when the mantle starts to exhume, the tip of the strongly thinned continental crust is still submitted to extension with new high-angle normal faults cutting through both crust and the brittle underlying mantle (Fig. 17d). With ongoing extension mantle continues to exhumed likely in a way comparable to ultra-slow spreading ridges, as suggested by Cannat et al., (2006; 2009), and possibly with bi-vergent rolling hinge systems (Fig. 15b) Note that this general model is based on laboratory experiments only for the initiation stage (Figs. 17a to c). The amplification stage is inspired from our own field studies (next section) and possible comparison with ultra-slow spreading ridges.

(5) Inferences from natural examples. The analogue models described above (Figs. 16 and 17) were initially performed to explore the mechanics of rifting leading to mantle exhumation, following the discovery of serpentinized peridotites at the tip of the magma poor West Iberian passive margin (e.g. Boillot et al., 1989). The retrograde petro-structural evolution of these rocks is compatible with an ascent beneath the rift zone and a final exhumation in the crustal breakup zone (Girardeau et al., 1988). On the Galicia, northern segment of the margin, partial melting occurred during the intense mylonitisation of the rocks in a normal sense shear zone dipping toward the margin, similar to the mantle shear zone created during the initiation stage of our model (Figs. 16c, 17b and c). The evolution includes the heterogeneous serpentinisation together with fracturing during the last exhumation stages. 
Like in the model, a system of tilted blocks in the upper crust characterizes the Galicia margin. Further south, in the Iberia Abyssal Plain segment, the weaker mylonitisation of the peridotites may correspond to a piece of high-strength sub-Moho mantle. The width of the zone of exhumed mantle between the continental and the oceanic crust increases southward, reaching more than $120 \mathrm{~km}$ in the Iberia Abyssal Plain. In this area, a series of horsts and grabens and intense fluid-assisted brecciation and fracturing accompanied the serpentinisation of the peridotites were interpreted as low temperature deformation of the exhumed mantle, after the continental crust breakup and before the onset of true oceanic accretion (Beslier et al., 1996). These late brittle deformations would correspond to the amplification stage in Figures $17 \mathrm{~d}$ and e. Whereas mantle rocks have been largely sampled through drilling and diving it must be noted that without in situ sampling of the lower crust and mantle rocks along the West Iberia margin, the validation of the model of mantle exhumation at passive margins (Fig. 17) could not have been completed.

An interplay between faulting in the brittle layers and decoupling-thinning along localized ductile décollements in ductile middle crust is observed in the fossil Alpine Thetys margins (Mohn et al., 2012). However, the Ronda peridotites in the Western Betics in South Spain (Navarro-Vila and Tubía, 1983), the largest continental peridotites massif worldwide, is the only field example that, up to now, provides quantified information on the deformation mechanisms occurring in the strongly thinned crust part and mantle at margin tip (Frasca et al., 2016) (Fig. 18). The peridotites were exhumed during Tertiary backarc rifting in the western Mediterranean and were thrust on top of the South Iberian passive margin soon after their exhumation, during the Miocene (Tubía et al., 1997; Mazzoli et al., 2013; Précigout et al., 2013; Johanesen and Platt, 2015). Figure 18a is a map of a small domain of the whole Ronda massif where two normal faults cutting through the sub-Moho mantle have controlled the tilting of three blocks (Agua, La Robla and Alozaina; Fig. 18b). Measurements of unit thicknesses in the three blocks document a strong gradient of thinning with the ductile crust passing from $1970 \mathrm{~m}$ in Agua to $1070 \mathrm{~m}$ in La Robla and to $70 \mathrm{~m}$ in Alozaina. The middle and lower crust are present in Agua and La Robla. In Alozaina the lower crust has totally disappeared and only a small remnant of the middle crust remains. The total thickness variation of the ductile crust, from $1970 \mathrm{~m}$ in Agua to $70 \mathrm{~m}$ in Alozaina, (Fig. 18c), corresponds to a layer-perpendicular finite strain $\lambda_{v}=0.04$ (i.e. $96 \%$ bulk shortening). In plane strain, this would imply a layer-parallel finite strain $\lambda_{\mathrm{h}}=25.0$ (i.e. a bulk stretching amount of $2400 \%$ ). Ductile deformation is associated to a medium-pressure/high-temperature 
metamorphism characterized by andalusite and sillimanite in the middle crust and reaching partial melting in the lowermost crust. Senses of shear associated to EW-trending stretching lineations (Fig. 18a) are top-to-W in the mantle, lower crust and lower part of the middle crust and top-to-NE in the upper part of the middle crust and in the upper crust. The superposition of brittle-ductile deformation on ductile fabrics indicates that the originally ductile crust cooled during thinning and became part of the brittle crust during extension. Where the ductile crust thickness reaches its lowest value top-to-NE shear affected both strongly thinned crust and serpentinized mantle. The normal faults that separate the three blocks indicate that the mantle has cooled extremely fast at margin tip. In summary, the Ronda peridotite massif provides an exceptional example of the deformation processes that occur at margin tip with an extreme thinning of the ductile crust, the partial melting of the lower crust and the vertical change of shear sense resulting from the contact in the necking zone between the shear zone located in the ductile crust (i.e. décollement) and the mantle shear zone that accommodated mantle rocks exhumation. This can be directly compared with the model of lithosphere stretching described above (Fig. 17).

Strong rifting-related heating of the continental crust, complementary of what is observed in Ronda, the North Pyrenean Zone (Clerc and Lagabrielle, 2014). The pre-rift Mesozoic sequences of the Cretaceous passive margin are characterized by high-temperature deformation in relation with thinning of the continental basement. Chronological and geological data show a clear correlation between the distribution of the highest paleotemperatures in the pre-rift sedimentary cover and the loci of extreme crustal stretching. Peridotite bodies directly underlying metamorphic pre-rift sediments indicate an early thinning of the rifted continental crust that likely occurred in the necking zone at margin tip.

\section{Conclusions}

The main conclusions concerning the mechanical processes that govern the development of crustal and mantle core complexes, using analogue and numerical models and comparison with some natural examples, are gathered under two complementary items: i) crustal versus mantle core complexes and ii) initiation and development of detachments.

It can be first stated in a very simplified way that two conditions are required for the development of a core complex: i) the availability of a thick "reservoir of weak ductile rocks" and ii) a localized stretching that strongly thins the high strength units overlying the reservoir. 
The existence of a thick reservoir of weak rocks in the continental crust primarily depends on the thermal state of the lithosphere, a good proxy of which being the initial Moho temperature. In the mantle, the source of weak ductile rocks able to exhume is not limited. The localization of stretching is favored by low rates of extension. Figure 19 that compares the general structure of crustal and mantle core complexes provides a graphical support to our main conclusions.

\subsection{Crustal versus mantle core complexes}

(1) Crustal core complexes develop in continental lithospheres whose Moho temperature is higher than $750^{\circ} \mathrm{C}$. In many core complexes, high-temperature metamorphism often reached partial melting, indicating Moho temperatures high enough to melt the middle and lower continental crust- i.e. in the range $700-800^{\circ} \mathrm{C}$. Characteristic strength profiles are "crust-dominated" with thick and weak ductile crust and lithospheric mantle (Fig. 19). Thermal weakening of the middle-lower crust occurs in crust strongly thickened by thrusting. But heating by thermal relaxation following thickening is a slow process. Shear delamination of crust from mantle that occurs in subduction zones affected by slab rollback brings the crust in direct contact with the asthenosphere. This leads to strong and fast heating and thermal weakening of the crust, either thickened or non-thickened. The Aegean back-arc domain, in which a thick thrust wedge has been delaminated from its underlying lithosphere mantle during slab rollback, provides examples of core complexes that developed sequentially in thickened and non-thickened crustal conditions. The Aegean also exemplifies that core complexes developed at low rate of extension $(0.6 \mathrm{~cm} / \mathrm{y})$ and that during the acceleration of trench retreat (up to $3.2 \mathrm{~cm} / \mathrm{y}$ ), the core complexes were overprinted by wide rift extension.

(2) Mantle core complexes develop in the oceanic lithosphere at slow and ultra-slow oceanic spreading ridges (Fig. 19). At slow spreading rates (e.g. MAR), mantle core complexes occur over $50 \%$ of the ridge length and are located on one side of the ridge axis, dominantly composed of mafic plutons and ultramafic mantle rocks whereas the other side is volcanic. At ultra-slow spreading rates (e.g. SWIR), both sides of the ridge axis are dominantly exhumed ultramafic mantle rocks with little or no axial volcanism. This striking structural-petrological difference between slow and ultra-slow spreading ridges suggests that the rate of extension plays an important role in core complex development at spreading ridges. In both types of setting, core complexes exhume below upward convex detachment faults. 
(3) Mantle core complexes develop in continental lithospheres, whose initial Moho temperature is lower than $750^{\circ} \mathrm{C}$, at the tip of magma-poor passive margins. The most commonly estimated Moho temperature for passive margins, used in several numerical models, is around $550^{\circ} \mathrm{C}$. At such temperature conditions, the lithosphere is characterized at first order by four-layer strength profiles with a ductile middle-lower crust able to decouple (i.e. décollement) the upper brittle crust from the underlying mantle with a layer-parallel shear top to the rift axis. The high-strength sub-Moho mantle undergoes a localized stretching that controls the ascent and exhumation of the underlying ductile mantle along shear zones with a shear sense top away from the rift axis. At lithosphere scale, the shear zones located along the ductile crust décollement and in the mantle, define two conjugate shear zones corresponding to a bulk symmetrical deformation pattern (i.e. pure shear). When the mantle has started to exhume and the width of exhumed mantle to enlarge, the mantle shear zones that accommodate mantle exhumation progressively migrate, with the rift axis, away from margin tip. In other words, there is no permanent detachment that control mantle exhumation since the onset of rifting. After the onset of mantle exhumation and before the creation of a volcanic crust, the process of mantle exhumation is likely comparable to one observed at ultra-slow spreading ridges.

(4) In continental lithosphere core complexes, the Moho strongly differs in terms of location and geometry: i) located inside the weak layer and remaining flat for crustal core complexes and ii) located inside the strong layer (crust plus sub-Moho mantle), arched and ultimately exhumed for mantle core complexes (magma-poor passive margins).

\subsection{Detachments}

(5) Contrary to what is commonly believed, the detachments that accommodate large exhumation of crustal core complexes do not initiate at the onset of extension. At initiation of extension, the upper brittle layer is affected by a graben-type structure whose enlargement allows the ductile layer to ascent. During its way to surface the top of the rising ductile crust is deformed in pure shear. This is exemplified by i) analogue and numerical models in which there is no pre-existing normal fault in the upper brittle layer and ii) natural examples like the Corinth rift below which the brittle-ductile transition is rising and core complexes like the Snake Range core complex that display pure shear deformation at the back part of the exhumed ductile crust. Detachments initiate during a second stage when the exhuming ductile crust approaches the surface. In other words, detachments are the product of progressive 
extension and not a fault initiating at an early stage of extension and whose displacement controls core complex exhumation.

(6) Analogue and numerical models confirm that convex upward detachments result from a rolling hinge process. This process is largely accepted for mantle core complexes at oceanic spreading ridges. In the continental crust, a number of well-documented crustal core complexes are interpreted in this way. However, many examples studied long ago were interpreted as product of displacement along a low-angle detachment. Therefore, the debate between low-angle and rolling hinge-type detachments implicitly remains, even if the concept of low-angle detachment cutting through the entire lithosphere gets no support from analogue or numerical modeling in more than three decades.

(7) Mantle exhumation at passive margins cannot be considered to result from a solitary detachment cutting through the entire lithosphere. The conjugate shear zones that accommodate the early mantle exhumation at margin tip migrate with the rift axis during increasing extension. Tilted blocks affecting the upper crust of conjugate margins result from layer-parallel shear (i.e. décollement) along the ductile crust whose intensity increases toward the rift axis. These shear zones are décollements and not detachments.

\section{Acknowledgements}

J.-P. B and C. T would like to express their gratitude to E. Burov for his matchless competence and kindness during more than a decade of open-minded and fruitful collaboration dedicated to the numerical modeling of core complexes and backarc extension. J.-P. B and J. VDD warmly thank G.H. Davis for his kind and enlightening introduction in 1985 to the core complexes of southern Arizona. M.-O. B and J.-P. B are extremely grateful to G. Boillot for involving them in his breakthrough discovery of mantle exhumation at the Galicia passive margin. Over more than 30 years, our field work, analogue and numerical modeling works concerning the topic of this paper have been funded by national institutions: INSU-CNRS, a 10 years IUF grant to J.-P. B, the ANR project EGEO (Lead by L. Jolivet) and our respective university institutes: University Paris 7 and IPG of Paris (J.-P. B and J. VDD), Géosciences Rennes (J.-P. B, F. G, C. T, J. VDD), Géosciences Montpellier (F.G), Geoazur Nice (formerly GEMCO) (M.-O. B), VU Amsterdam (D. S) and Earth Sciences Department of Utrecht University (D. S and C. T). Along years, we benefited from discussions with numerous colleagues among whom we thank in particular J.-P. Burg, C. 
Faccenna, L. Jolivet, D. Kostopoulos and L. Royden who, however, do not necessarily share all the ideas expressed here. Great thanks to Xavier Fort for his help with figure design. We thank Chief Editor P. Agard and the Guest Manager Editor for manuscript handling, to P. Rey and two anonymous reviewers for critical comments. Detailed issues and constructive suggestions made by the reviewers were extremely helpful for improving our manuscript.

\section{References}

Allemand, P., Brun, J.-P., 1991. Width of continental rifts and rheological layering of the lithosphere. Tectonophysics 188, 63-69.

Allmendinger, R.W., Hauge, T.A., Hauser, E.C., Potter, C.J., Klemperer, S.L.,Nelson, K.D., Knuepfer, P., Oliver, J., 1987. Overview of the COCORP 40_N Transect, western United States: The fabric of an orogenic belt. Geological Society of America Bulletin 98, 308 - 319. doi:10.1130/0016- 7606(1987)98<308:OOTCNT>2.0.CO;2.

Armijo, R., Tapponnier, P., Mercier, J.L., Han, T.-L., 1986, Quaternary extension in southern Tibet: Field observations and tectonic implications: Journal of Geophysical Research 91, 13,803-13,872.

Armstrong, R.L., 1982. Cordilleran metamorphic core complexes-from Arizona to southern Canada. Annual Review of Earth and Planetary Sciences 10, 129-154.

Axen, G.J., 2004, Mechanics of low-angle normal faults, in Karner, G.D., et al., eds., Rheology and Deformation of the Lithosphere at Continental Margins: New York, Columbia University Press, p. 46-91.

Axen, G.J., Bartley, J.M., 1997. Field tests of rolling hinges: Existence, mechanical types, and implications for extensional tectonics. Journal of Geophysical Research 102, 20,51520,537 .

Beaumont, C., Ings, S.J. 2012. Effect of depleted continental lithosphere counterflow and inherited crustal weakness on rifting of the continental lithosphere: General results. Journal of Geophysical Research 117. doi:10.1029/2012JB009203

Berthe, D., Choukroune, P., and Jegouzo, P., 1979. Orthogneiss, mylonite and non coaxial deformation of granites: the example of the South Armorican Shear Zone. Journal of Structural Geology 1, 31-42, doi:10.1016/0191-8141(79)90019-1.

Beslier, M.O., Girardeau, J., Boillot, G., 1990. Kinematics of peridotite emplacement 
during North Atlantic continental rifting, Galicia, northwestern Spain. Tectonophysics 184, $321-343$

Beslier, M-O., Cornen, G., Girardeau, J., 1996. Tectono-metamorphic evolution of peridotites from the ocean/continent transition of the Iberia Abyssal Plain margin. Whitmarsh, R.B., Sawyer, D.S., Klaus, A., Masson, D.G. (Eds.), Proc. ODP, Scientific Results 149: College Station, TX (Ocean Drilling Program), 397-412.

Blackman, D.K., Canales, J.P., Harding, A., 2009. Geophysical signatures of oceanic core complexes. Journal of Geophysical Research 178, 593-613. doi: 10.1111/j.1365246X.2009.04184.X

Block, L., Royden, L.H., 1990. Core complex geometries and regional scale flow in the lower crust. Tectonics 9, 557-567. doi:10.1029/TC009i004p00557.

Boillot, G., Recq, M., Winterer, E.L., Meyer, A.W., Applegate, J., Baltuck, M., Bergen, J.A., Comas, M.C., Davies, T.A., Dunham, K., Evans, C.A., Girardeau, J., Goldberg, G., Haggerty, J., Jansa, L.F., Johnson, J.A., Kasahara, J., Loreau, J.P., Lunasierra, E., Moullade, M., Ogg, J., Sarti, M., Thurow, J., Williamson, M., 1987. Tectonic denudation of the upper mantle along passive margins: A model based on drilling results (ODP LEG103, Western Galicia Margin, Spain). Tectonophysics 132, 335-342.

Boillot, G., Féraud, G., Recq, M., Girardeau, J., 1989. Undercrusting by serpentinite beneath rifted margins. Nature 341, 523-525.

Brun, J.-P., 1999. Narrow rifts versus wide rifts: inferences for the mechanics of rifting from laboratory experiments. Philosophical Transaction of the Royal Society, London, A, 357, 695-710.

Brun, J.-P. and Choukroune, P.,1983. Normal faulting, block tilting and décollement in a stretched crust. Tectonics, 2, 4, 345-356.

Brun, J.-P., van den Driessche, J., 1994. Extensional gneiss domes and detachment fault systems-Structure and kinematics. Bulletin de la Société Géologique de France 165, $519-530$.

Brun, J.-P., Sokoutis, D., van den Driessche, J., 1994. Analogue modeling of detachment fault systems and core complexes. Geology 22, 319-322, doi:10.1130 /00917613(1994)022<0319:AMODFS>2.3.CO;2.

Brun, J.-P., Beslier, M.O.,1996. Mantle exhumation at passive margins. Earth and Planetary Science Letters 142, 161-173.

Brun, J.-P., Sokoutis, D., 2007. Kinematics of the Southern Rhodope Core Complex 
(north Greece). International Journal of Earth Sciences 96, 1079-1099. doi:10.1007/s00531-007-0174-2.

Brun, J.-P., Faccenna, C., 2008. Exhumation of high-pressure rocks driven by slab rollback. Earth and Planetary Science Letters 272: 1-7. doi:10.1016/j.epsl. 2008.02.038.

Brun, J.P., Sokoutis, D., 2010. 45 m.y. of Aegean crust and mantle flow driven by trench retreat. Geology 38, 815-818.

Brun, J.-P., Faccenna, C., Gueydan, F., Sokoutis, D., Philippon, M., Kydonakis, K., Gorini, C. 2016. The two-stage Aegean extension, from localized to distributed, a result of slab rollback acceleration. Canadian Journal of Earth Sciences 53, 1142-1157. doi:10.1139/cjes-2015-0203.

Brune, S., Heine, C., Perez-Gussinye, M., Sobolev, S.V., 2014. Rift migration explains continental margin asymmetry and crustal hyper-extension, Nature Communications 5(4014), doi:10.1038/ncomms5014.

Brune, S., Heine, C., Clift, P.D., Pérez-Gussinyé, M., 2017. Rifted margin architecture and crustal rheology: Reviewing Iberia-Newfoundland, Central South Atlantic, and South China Sea. Marine and Petroleum Geology 79, 257-281. http://dx.doi.org/10.1016/j.marpetgeo.2016.10.0180264-8172/

Buck, W.R., 1988. Flexural rotation of normal faults. Tectonics 7, 959-973. doi:10.1029/TC007i005p00959.

Buck, W.R., 1991. Modes of continental lithospheric extension. Journal of Geophysical Research 96, 20,161-20,178. doi:10.1029/91JB01485.

Burg, J.-P., 2011. Rhodope: From Mesozoic convergence to Cenozoic extension. Review of petro-structural data in the geochronological frame. In The Geology of Greece. Edited by E. Skourtsos and G.S. Lister. Journal of the Virtual Explorer Vol. 42.

Burg, J. P., Van Den Driessche J., Brun, J.-P., 1994. Syn to post-thickening extension in the Variscan Belt of western Europe: Modes and structural consequences. Geologie de la France 3, 33-51.

Burov, E.B., 2007a. Plate rheology and mechanics. In: Schubert, G., Watts, A.B. (Eds.), Treatise on Geophysics. Crust and Lithosphere Dynamics, vol. 6. Elsevier, 99-152.

Burov, E.B., 2007b. The role of gravitational instabilities, density structure and extension rate in the evolution of continental margins. In : Karner, G. D., Manatschal, G. \& Pinheiro, L. M. (eds), Imaging, Mapping and Modelling Continental Lithosphere Extension and Breakup. Geological Society, London, Special Publications, 282, 139-156. DOI: 10.1144/SP282.7 0305-8719/07/\$15.00 
Burov, E.B., 2010. The equivalent elastic thickness (Te), seismicity and the long-term rheology of continental lithosphere: time to burn-out "crème brûlée"? Insights from largescale geodynamic modeling. Tectonophysics 484, 4-26.

http://dx.doi.org/10.1016/j.tecto.2009.06.013

Burov, E., 2011. Rheology and strength of the lithosphere. Marine and Petroleum Geology 28, 1402-1443. http://dx.doi.org/10.1016/j.marpetgeo.2011.05.008.

Canales, J.P., Tucholke, B.E., Collins, J.A., 2004. Seismic reflection imaging of an oceanic detachment fault: Atlantis megamullion (Mid-Atlantic Ridge, 30॰10’ N), Earth and Planetary Science Letters 222, 543-560.

Cann, J.R., Blackman, D.K., Smith, D.K., McAllister, E., Janssen, B., Mello, S., Avgerinos, E., Pascoe, A.R., and Escartin, J., 1997. Corrugated slip surfaces formed at North Atlantic ridge-transform intersections. Nature 385, 329-332. doi:10.1038/385329a0. Cannat, M., Mendel, V., Ruellan, E., Okino, K., Escartin, J., Combier, V., and Baala, M., 2006. Modes of seafloor generation at a melt-poor ultraslow-spreading ridge. Geology 34, 605-608. doi:10.1130/G22486.1.

Cannat, M., Manatschal, G., Sauter, D., Péron-Pinvidic, G., 2009. Assessing the conditions of continental breakup at magma-poor rifted margins: What can we learn from slow spreading mid-ocean ridges? C. R. Geoscience 341, 406-427.

Chéry, J., 2001. Core complex mechanics: From the Gulf of Corinth to the Snake Range. Geology 29, 439-442, doi : 10.1130/0091-7613(2001) 029<0439:CCMFTG>2.0.CO;2.

Clerc, C., Lagabrielle, Y., 2014. Thermal control on the modes of crustal thinning leading to mantle exhumation : Insights from the Cretaceous Pyrenean hot paleomargins. Tectonics 33, 1340-1359, doi :10.1002/2013TC003471.

Collettini, C., 2011. The mechanical paradox of low-angle normal faults: Current understanding and open questions. Tectonophysics, 510, 253-268. doi:

10.1016/j.tecto.2011.07.015

Compton, R. R., 1980. Fabrics and strains in quartzites of a metamorphic core complex, Raft River Mountains, Utah. In : Cordilleran Metamorphic Core Complexes (edited by Crittenden, M. D., Jr. Coney, P. J. \& Davis. G. H.). Mem, geol. Soc. Am. 153, 385-398.

Coney, P.J., 1974. Structural analysis of the Snake Range «décollement » east-central Nevada. Geological Society of America Bulletin, 85, 973-978.

Coney, P.J., 1980. Cordilleran metamorphic core complexes: An overview, in Crittenden, M.D., Coney, P.J., and Davis, G.H., eds., Cordilleran Metamorphic Core Complexes. Geological Society of America Memoir 153, 7-34. 
Coney, P., 1987. The regional tectonic setting and possible causes of Cenozoic extension in the North American Cordillera. in Coward, M.P., Dewey, J.F., and Hancock, P.L. (eds.), Continental Extensional Tectonics. Geological Society of London Special Publication 28, 177-186. doi: 10.1144/GSL.SP.1987.028.01.13.

Coney, P.J., Harms, T.A., 1984. Cordilleran metamorphic core complexes: Cenozoic extensional relics of Mesozoic compression. Geology 12, 550-554. doi:10.1130 /00917613(1984)12<550:CMCCCE $>2.0 . \mathrm{CO} ; 2$.

Cooper, F.J., Platt, J.P., Platzman, E.S., Grove, M.J., Seward, G., 2010. Opposing shear senses in a subdetachment mylonite zone: Implications for core complex mechanics. Tectonics 29, TC4019.

Cosca, M.A., Essene, E.J., Mezger, K., van der Pluijm, B.A., 1995, Constraints on the duration of tectonic processes: Protracted extension and deep-crustal rotation in the Grenville orogen. Geology 23, 361-364.

Crittenden, Jr, Coney, P. J., Davis, G, 1978. Tectonic significance of metamorphic cores complexes in the North American Cordillera. Geology 6, 79-80.

Crittenden, M.D., Jr., Coney, P.J., Davis, G.H., eds., 1980. Cordilleran Metamorphic Core Complexes. Geological Society of America Memoir 153, 490.

Davis, G.A., and Lister, G.S., 1988, Detachment faulting in continental extension; perspectives from the southwestern U.S. Cordillera, in Clark, S.P., Jr., Processes in continental lithospheric deformation: Geological Society of America Special Paper 218, 133-159.

Davis, G.A., Lister, G.S., Reynolds, S.J., 1986. Structural evolution of the Whipple and South Mountains shear zones, southwestern United States. Geology, 14, 7-10. doi:10.1130/0091-7613(1986)14<7:SEOTWA>2.0.CO;2.

Davis, G. H., 1980. Structural characteristics of metamorphic core complexes, southern Arizona, in Cordilleran Metamorphic Core Complexes, edited by M. C. Crittenden et al., Geological Society of America Memoir 153, 35-77.

Davis, G. H., 1983. Shear-zone model for the origin of metamorphic core complexes. Geology 11, 342-347. doi:10.1130/0091-7613(1983)11<342:SMFTOO>2.0.CO;2.

Davis, G.H., 1987. A shear-zone model for the structural evolution of metamorphic core complexes in southeastern Arizona, in Coward, M.P., Dewey, J.F., and Hancock, P.L. (eds.), Continental Extensional Tectonics. Geological Society of London Special Publication 28, 247-266.

Davis, G.H., Coney, P.J., 1979. Geologic development of the Cordilleran metamorphic 
core complexes. Geology 7, 120-124. doi:10.1130/0091-7613 (1979)7<120:GDOTCM>2.0.CO;2.

Davis, G.H., Constenius, K.N., Dickinson, W.R., Rodriguez, E.P., Cox, L.J., 2004. Fault and fault-rock characteristics associated with Cenozoic extension and core-complex evolution in the Catalina-Rincon region, southeastern Arizona. Geological Society of America Bulletin 116, 128-141.

de Martin, B.J., Canales, R.A.R., Canales, J.P., Humphris, S.E., 2007, Kinematics and geometry of active detachment faulting beneath the Trans-Atlantic Geotraverse (TAG) hydrothermal fi eld on the Mid- Atlantic Ridge: Geology v. 35, p. 711-714, doi:10.1130 /G23718A.1.

Dewey, J. F., 1988. Extensional collapse of orogens. Tectonics 7, 1123- 1139.

Dick, H.J.B., Thompson, G., Bryan, W.B., 1981. Low angle faulting and steady-state emplacement of plutonic rocks at ridge-transform intersections. Eos Transactions AGU, $62,406$.

Dick, H.J.B., Lin, J., and Schouten, H., 2003. An ultraslow-spreading class of ocean ridge: Nature 426, 405-412.

Duretz, T., Petri, B., Mohn, G., Schmalholz, S.M., Schenker, F.L. Müntener, O., 2016. The importance of structural softening for the evolution and architecture of passive margins. Scientific Reports | 6:38704 |DOI: 10.1038/srep38704

Escartín, J., Mevel, C., MacLeod, C.J., McCaig, A.M., 2003. Constraints on deformation conditions and the origin of oceanic detachments: The Mid-Atlantic Ridge core complex at $15^{\circ} 4{ }^{\prime} \mathrm{N}$. Geochemistry, Geophysics and Geosystems 4, 1067, doi:10.1029/2002GC000472.

Escartín, J., Smith, D.K., Cann, J., Schouten, H., Langmuir, C.H., Escrig, S., 2008. Central role of detachment faults in accretion of slow-spreading oceanic lithosphere. Nature 455. doi:10.1038/nature07333.

Faccenna, C., Jolivet, L., Piromallo, C., Morelli, A., 2003. Subduction and the depth of convection in the Mediterranean mantle. Journal of Geophysical Research 108: 2099. doi:10.1029/2001JB001690.

Faccenna C., Becker T.W., Auer L., Billi A., Boschi L., Brun J.-P., Capitanio F.A., Funiciello F., Horvàth F., Jolivet L., Piromallo C., Royden L., Rossetti F., Serpelloni E., 2014. Mantle dynamics in the Mediterranean. Review of Geophysics 52, doi: 10.1002/2013RG000444

Fitz, G., Mann, P., 2013. Tectonic uplift mechanism of the Goodenough and Fergusson 
Island gneiss domes, eastern Papua New Guinea: Constraints from seismic reflection and well data. Geochemistry, Geophysics and Geosystems 14. doi: 10.1002/ggge.20208.

Flotté, N., Sorel, D., Müller, C., Tensi, J., 2005. Along strike changes in the structural evolution over a brittle detachment fault: example of the Pleistocene Corinth-Patras rift (Greece). Tectonophysics 403, 77-94.

Frasca, G., Gueydan, F., Brun, J.-P., Monié, P., 2016. Deformation mechanisms in a continental rift up to mantle exhumation. Field evidence from the western Betics, Spain. $\begin{array}{llll}\text { Marine } \text { and } \quad \text { Petroleum } & \text { 1-19, }\end{array}$ http://dx.doi.org/10.1016/j.marpetgeo.2016.04.020.

Gans, P.B., 1987. An open-system, two layer crustal stretching model for the eastern Great Basin. Tectonics 6, 1-12.

Gans, P.B., Miller, E.L., McCarthy, J., Ouldcott, M.L., 1985. Tertiary extensional faulting and evolving ductile-brittle transition zones in the northern Snake Range and vicinity: New insights from seismic data. Geology 13, 189-193. doi:10.1130/0091-7613 (1985)13<189:TEFAED>2.0.CO;2.

Garcés, M., Gee, J.S., 2007. Paleomagnetic evidence of large footwall rotations associated with low-angle faults at the Mid-Atlantic Ridge. Geology 35, 279-282. doi :10.1130/G23165A.1.

Gaudemer, Y., Jaupart, C., Tapponnier, P., 1988. Thermal control on post-orogenic extension in collision belts. Earth and Planetary Science Letters 89, 48- 62.

Gessner, K., Wijns, C., Moresi, L., 2007. Significance of strain localization in the lower crust for structural evolution and thermal history of metamorphic core complexes. Tectonics 26. doi :10.1029/2004TC001768.

Girardeau, J., Evans, C.A., Beslier, M-O., 1988. Structural analysis of plagioclase-bearing peridotites emplaced at the end of continental rifting: Hole 637A, ODP Leg 103 on the Galicia margin. Boillot, G., Winterer, E.L., et al. (Eds.), Proc. ODP, Scientific Results 103: College Station, TX (Ocean Drilling Program), 209-223.

Gueydan, F., Morency, C., Brun, J.-P., 2008. Continental rifting as a function of lithosphere mantle strength. Tectonophysics 460, 83-93. doi:10.1016/j.tecto.2008.08.012 Harry, D.L., Grandel, S., 2007. A dynamic model of rifting between Galicia Bank and Flemish Cap during the opening of the North Atlantic Ocean. In Karner, G. D., Manatschal, G. and Pinheiro, L. M. (eds) Imaging, Mapping and Modelling Continental Lithosphere Extension and Breakup. Geological Society Special Publications 282, 157172. doi : $10.1144 /$ SP282.8 0305-8719/07/\$15.00 
Hauge, T., Allmendinger, R., Caruso, C., Hauser, E., Klemperer, S., Opdyke, S., Potter, C., Sanford, W., Brown, L., Kaufman, S., Oliver, J., 1987. Crustal structure of western Nevada from COCORP deep seismic-reflection data. Geological Society of America Bulletin 98, 320-329. doi :10.1130/0016-7606(1987)98<320:CSOWNF>2.0.CO;2.

Hauser, E., Burgess, S., Burtch, S., Mutschler, J., Potter, C., Hauge, T., Allmendinger, R., Brown, L., Kaufman, S. \& Oliver, J., 1987a. Crustal structure of eastern Nevada from COCORP deep seismic reflection data. Geological Society of America Bulletin 99, 833844. doi :10.1130/0016-7606(1987)99<833:CSOENF>2.0.CO;2.

Hauser, E.C., Gephart, J., Latham, T., Oliver, J., Kaufman, S., Brown, L., Lucchitta, I., 1987b. COCORP Arizona transect: Strong crustal reflections and offset Moho beneath the transition zone. Geology 15, 1103-1106.

Henyey, T.E., D.A. Okaya, D.A., Frost, E.G., McEvilly, T.V., 1987. CALCRUST (1985) seismic reflection survey, Whipple Mountains detachment terrane, California: An overview. Geophysical Journal of the Royal Astronomical Society 89, 111-118.

Hubbert, M. K., Rubey, W. W., 1959. Role of fluid pressure in mechanics of overthrust faulting. Geological Society of America Bulletin, 70, 115-206.

Huet, B., Le Pourhiet, L., Labrousse, L., Burov, E., Jolivet, L., 2010. Post-orogenic extension and metamorphic core complexes in a heterogeneous crust: the role of crustal layering inherited from collision. Application to the Cyclades (Aegean domain). Geophysical Journal International 184, 611-625. doi: 10.1111/j.1365-246X.2010.04849.x Huismans, R. S., Beaumont, C., 2007. Roles of lithospheric strain softening and heterogeneity in determining the geometry of rifts and continental margins. In Karner, G. D., Manatschal, G. and Pinheiro, L. M. (eds) Imaging, Mapping and Modelling Continental Lithosphere Extension and Breakup. Geological Society, London, Special Publications 282, 111-138.

Johanesen, K., Platt, J.P., Kaplan, M.S., Ianno, A.J., 2014. A revised thermal history of the Ronda Peridotite, S. Spain: new evidence for excision during exhumation. Earth and Planetary Science Letters 393, 187-199.

Jolivet, L., Brun, J.-P., 2010. Cenozoic geodynamic evolution of the Aegean. International Journal of Earth Sciences 99, 109-138. doi :10.1007/s00531-008-0366-4.

Jolivet, L., Labrousse, L., Agard, P., Lacombe, O., Bailly, V., Lecomte, E., Mouthereau, F., Mehl, C., 2010. Rifting and shallow-dipping detachments, clues from the Corinth Rift and the Aegean. Tectonophysics 483, 287-304.

Kapp, P., Taylor, M., Stockli, D., Ding, L., 2008. Development of active low-angle 
normal fault systems during orogenic collapse: Insight from Tibet. Geology 36, 7-10. doi : 10.1130/G24054A.1

Kehle, R.O., 1970. Analysis of Gravity Sliding and Orogenic Translation. Geological Society of America Bulletin, 81, 1641-1664.

Klemperer, S. L., Hauge, T.A., Hauser, E.C., Oliver, J.E., Potter, C.J., 1986. The Moho in the northern Basin and Range Province, Nevada, along the COCORP $40^{\circ} \mathrm{N}$ seismic reflection transect. Geological Society of America Bulletin 97, 603-618. doi:10.1130/0016 7606(1986)97<603: TMITNB>2.0.CO;2

Koyi, H.A., Skelton, A., 2001. Centrifuge modelling of the evolution of low-angle detachment faults from high-angle normal faults. Journal of Structural Geology 23, 11791185. doi :10.1016/S0191-8141(00)00185-1.

Kruse, S., McNutt, M., Phipps-Morgan, J., Royden, L., Wernicke, B., 1991. Lithospheric extension near Lake Mead, Nevada : A model for ductile flow of the lower crust. Journal of Geophysical Research 96, 4435-4450. doi:10.1029/90JB02621.

Kydonakis, K., Brun, J.-P., Sokoutis, D., (2015a), North Aegean core complexes, the gravity spreading of a thrust wedge, Journal of Geophysical Research 120, doi :10.1002/2014JB011601.

Kydonakis, K., Brun, J.-P., Sokoutis, D., Gueydan, F., (2015b). Kinematics of Cretaceous subduction and exhumation in the western Rhodope (Chalkidiki block). Tectonophysics, 665, 218-235. http://dx.doi.org/10.1016/j.tecto.2015.09.034.

Lagabrielle, Y., 2009. Mantle exhumation and lithospheric spreading: An historical perspective from investigations in the Oceans and in the Alps-Apennines ophiolites. Italian Journal of Geosciences (Bollettino della Società Geologica Italiana) 128, 279-293. Lagabrielle, Y., Lemoine, M., 1997. Alpine, Corsican and Apennine ophiolites : the slow spreading ridge model. Concise review paper. C.R. Académie des Sciences 325, 909-920. Lavier, L.L., Buck, W.R., Poliakov, A.N.B., 1999. Selfconsistent rolling-hinge model for the evolution of large-offset, low-angle normal faults. Geology 27, 1127-1130, doi:10.1130/0091-7613(1999)027 <1127:SCRHMF>2.3.CO;2.

Lavier, L.L., Buck, W.R., Poliakov, A.N.B., 2000. Factors controlling normal fault offset in an ideal brittle layer. Journal of Geophysical Research 105, 23,431- 23,442. doi:10.1029/2000JB900108.

Lavier, L.L., Buck, W.R., 2002. Half graben versus large-offset low-angle normal fault: The importance of keeping cool during normal faulting. Journal of Geophysical Research 107, 2122, doi:10.1029/2001JB000513. 
Lavier, L.L., Manatschal, G., 2006. A mechanism to thin the continental lithosphere at magma-poor margins. Nature 440, 324-328. doi:10.1038/nature04608.

Lee, J., Miller, E.L., Sutter, J.F., 1987. Ductile strain and metamorphism in an extensional tectonic setting: a case study from the northern Snake Range, Nevada, USA. In: Coward, M.P., Dewey, J.F. \& Hancock, P.L. (eds) Continental Extensional Tectonics. Geological Society Special Publications 28, 267-298.

Le Pourhiet, L., Burov, E., Moretti, I., 2004. Rifting through a stack of inhomogeneous thrusts (the dipping pie concept). Tectonics 23, TC4005. doi:10.1029/2003TC001584.

Lister, G.A., Etheridge, M.A., Symonds, P.A., 1986. Detachment faulting and the evolution of passive continental margins, Geology 14, 246-250.

Lister, G.S., Davis, G.A., 1989. The origin of metamorphic core complexes and detachment faults formed during Tertiary continental extension in the northern Colorado River region, USA. Journal of Structural Geology 11, 65-94. doi:10.1016/0191-8141 (89)90036-9.

Little, T.A., Hacker, B.R., Gordon, S.M., Baldwin, S.L., Fitzgerald, P.G., Ellis, S., Korchinski, M., 2011. Diapiric exhumation of Earth's youngest (UHP) eclogites in the gneiss domes of the D'Entrecasteaux Islands, Papua New Guinea. Tectonophysics 510, $39-68$.

MacLeod, C.J., Escartin, J., Banerji, D., Banks, G.J., Gleeson, M., Irving, D.H.B., Lilly, R.M., McCaig, A.M., Niu, Y., Allerton, S., and Smith, D.K., 2002, Direct geological evidence for oceanic detachment faulting: The Mid-Atlantic Ridge, $15^{\circ} 45^{\prime}$ N: Geology v. 30, p. 879-882. doi:10.1130/0091-7613(2002)030<0879: DGEFOD>2.0.CO;2.

Martinez, F., Goodliffe, A., Taylor, B., 2001. Metamorphic core complex formation by density inversion and lower crustal extrusion. Nature 411, 930-933.

McCarthy, J., Larkin, S.P., Fuis, G.S., Simpson, R.W., Howard, K.A.,1991. Anatomy of a metamorphic core complex: Seismic refraction/ wide - angle reflection profiling in southeastern California and western Arizona. Journal of Geophysical Research 96, 12,259-12,291. doi:10.1029/91JB01004.

Mazzoli, S., Martín-Algarra, A., 2011. Deformation partitioning during transpressional emplacement of a «mantle extrusion wedge »: the Ronda peridotites, Western Betic Cordillera, Spain. Journal of the Geological Society London. 168, 373-382.

McKenzie, D., Nimmo, F., Jackson, J.A., Gans, P.B., Miller, E.L., 2000. Characteristics and consequences of flow in the lower crust. Journal of Geophysical Research 105, 
11,029-11,046, doi:10.1029/1999JB900446.

Mezri, L., Le Pourhiet, L., Wolf, S., Burov, E. 2015. New parametric implementation of metamorphic reactions limited by water content, impact on exhumation along detachment faults. Lithos 236-237, 287-298.

Miller, E.L., Gans, P.B., Garlin, J., 1983. The Snake River décollement: An exhumed mid-Tertiary brittle-ductile transition. Tectonics 2, 239-263. doi:10.1029 /TC002i003p00239.

Miller, E.L., Dumitru, T.A., Brown, R.W., Gans, P.B., 1999. Rapid Miocene slip on the Snake Range-Deep Creek Range fault system, east-central Nevada. Geological Society of America Bulletin 111, 886-905.

Mohn, G., Manatschal, G., Beltrando, M., Masini, E., Kusznir, N., 2012. Necking of continental crust in magma-poor rifted margins: evidence from the fossil Alpine Tethys margins. Tectonics 31, TC1012. http://dx.doi.org/10.1029/2011TC002961

Morris, A., Gee, J.S., Pressling, N., John, B.E., MacLeod, C.J., Grimes, C.B., and Searle, R.C., 2009, Footwall rotation in an oceanic core complex quantifi ed using reoriented Integrated Ocean Drilling Program core samples: Earth and Planetary Science Letters 287, 217-228. doi:10.1016/j.epsl.2009.08.007.

Nagel, T. J., Buck, W.R., 2004. Symmetric alternative to asymmetric rifting models. Geology 32, 937-940. doi:10.1130/G20785.1.

Nagel, T.J., Buck, W.R., 2007. Control of rheological stratification on rifting geometry: a symmetric model resolving the upper plate paradox. International Journal of Earth Sciences 96, 1047-1057. DOI 10.1007/s00531-007-0195-x.

Navarro-Vila, F., Tubía, J., 1983. Essai d'une nouvelle différenciation des nappes Alpujarrídes dans le secteur occidental des Cordillères Bétiques (Andalousie, Espagne). C. R. Académie des Sciences Paris 296, 111-114.

Nestola, Y., Storti, F., Bedogni, E., Cavozzi, C., 2013. Shape evolution and finite deformation pattern in analog experiments of lithosphere necking, Geophysical Research Letters 40, 1-6. doi:10.1002/grl.50978

Neumayr, P., Hoinkes, G., Puhl, J., Mogessie, A., Khudeir, A.A., 1998. The Meatiq dome (Eastern Desert, Egypt) a Precambrian metamorphic core complex: petrological and geological evidence. Journal of Metamorphic Geology 16, 259-279.

Nestola, Y., Storti, F., Bedogni, E., Cavozzi, C., 2015. Strain rate-dependent lithosphere rifting and necking architectures in analog experiments, Journal of Geophysical Research 120. doi:10.1002/2014JB011623. 
Peron-Pinvidic, G., Manatschal, G., Osmundsen, P.T., 2013. Structural comparison of archetypal Atlantic rifted margins: a review of observations and concepts. Marine and Petroleum Geology 43, 21-47.

Philippon, M., Brun, J.P., Gueydan, F. 2012. Deciphering subduction from exhumation in the segmented Cycladic Blueschist Unit (Central Aegean, Greece). Tectonophysics 524: 116-134. doi:10.1016/j.tecto.2011.12.025.

Platt, J.P., Behr, W.M., Frances J. Cooper, F.J., 2015. Metamorphic core complexes: windows into the mechanics and rheology of the crust. Journal of the Geological Society 172, 9-27. doi:10.1144/jgs2014-036

Précigout, J., Gueydan, F., Garrido, C.J., Cogné, N., Booth-Rea, G., 2013. Deformation and exhumation of the Ronda peridotite (Spain). Tectonics 32, 1011-1025.

Ramsay, J.G. Huber, M.I., 1987. The Techniques of Modern Structural Geology: Folds and Fractures. Academic Press, London, 700 p.

Ranalli, G., Murphy, D.C.,1987. Rheological stratification of the lithosphere, Tectonophysics 132, 281- 295.

Ranero, C.R., Reston, T.J., 1999. Detachment faulting at ocean core complexes. Geology 27, 983-986. doi:10.1130/0091-7613(1999)027<0983:DFAOCC >2.3.CO;2.

Rehrig, W. A., Reynolds, S.J., 1980. Geologic and geochronologic reconnaissance of a northwest-trending zone of metamorphic core complexesin southern and western Arizona, in Cordilleran Metamorphic Core Complexes, edited by M. C. Crittenden et al., Geological Society of America Memoir 153, 131- 158.

Rey, P., Teyssier, C., Whitney, D.L., 2009a. Crustal melting and core complex dynamics. Geology 37, 391-394. doi:10.1130/G25460A.1.

Rey, P., Teyssier, C., Whitney, D.L., 2009b. The role of partial melting and extensional strain rates in the development of metamorphic core complexes (McMCC). Tectonophysics 477, 135-144. doi:10.1016/j.tecto.2009.03.010.

Rey, P.F., Teyssier, C., Kruckenberg, S.C., Whitney, D.L., 2011. Viscous collision in channel explains double domes in metamorphic core complexes. Geology 39, 387-390. doi:10.1130/G31587.1.

Reynolds, S. J., Lister, G.S., 1990. Folding of mylonitic zones in Cordilleran metamorphic core complexes: Evidence from near the mylonitic front. Geology 18, 216-219.

Reynolds, S. J., Rehrig, W. A., 1980. Mid-Tertiary plutonism and mylonitization, South Mountains, central Arizona, In: Cordilleran Metamorphic Core Complexes (edited by Crittenden, M. D., Jr. Coney, P. J. \& Davis. G. H.). Geological Society of America 
Memoir 153, 159-175.

Rigo, A., Lyon-Caen, H., Armijo, R., Deschamps A., Hatzfeld, D., Makropoulos, K., Papadimitriou, P., Kassaras, I., 1996. A microseismic study in the western part of the Gulf of Corinth (Greece): Implications for large-scale normal faulting mechanisms. Geophysical Journal of the Royal Astronomical Society 126, 663-688.

Rohais, S., Joannin, S., Colin, J.P., Suc, J.P., Guillocheau, F., Eschard, R., 2007b. Age and environmental evolution of the syn-rift fill of the southern coast of the Gulf of Corinth (Akrata-Derveni region, Greece). Bulletin de la Société Géologique de France 178, 231243.

Rosenbaum, G., Regenauer - Lieb, K., Weinberg, R.F., 2010. Interaction between mantle and crustal detachments: A nonlinear system controlling lithospheric extension. Journal of Geophysical Research 115, B11412. doi:10.1029/2009JB006696.

Sauter, D., Cannat, M., Roumejon, S., Andreani, M., Birot, D., Bronner, A., Brunelli, D., Carlut, J., Delacour, A., Guyader, V., MacLeod, C. J., Manatschal, G., Mendel, V., Menez, B., Pasini, V., Ruellan, E., and Searle, R., 2013. Continuous exhumation of mantlederived rocks at the southwest indian ridge for 11 million years, Nature Geosciences 6, 314-320.

Schenker, F.L., Gerya, T., Burg, J.-P., 2012. Bimodal behavior of extended continental lithosphere: Modeling insight and application to thermal history of migmatitic core complexes. Tectonophysics 579, 88-103.

Schmalholz, S.M., Mancktelow, N.S., 2016. Folding and necking across the scales: a review of theoretical and experimental results and their applications. Solid Earth 7, 14171465. doi:10.5194/se-7-1417-2016

Skourtsos, E., Kranis, H., (2009) Structure and evolution of the western Corinth Rift, through new field data from the Northern Peloponnesus. In Ring, U. \& Wernicke, B. (eds) Extending a Continent: Architecture, Rheology and Heat Budget. Geological Society Special Publications 321, 119-138. doi: 10.1144/SP321.6 0305-8719/09.

Snoke, A.W., 1980. Transition from infrastructure to suprastructure in the northern Ruby Mountains, Nevada, in Crittenden, M.D., Jr., Coney, P.J., and Davis, G.H., eds., Cordilleran metamorphic core complexes: Geological Society of America Memoir 153, 287-333.

Sonder, L.J., England, P.C., Wernicke, B.P., Christiansen, R.L., 1987. A physical model for Cenozoic extension of western North America. In: Coward, M.P., Dewey, J.F. \& Hancock, P.L. (eds) Continental Extensional Tectonics. Geological Society Special 
Publications 28, 187-201.

Sorel, D., 2000. A Pleistocene and still-active detachment fault and the origin of the Corinth-Patras rift, Greece. Geology 28, 83-86.

Spencer, J.E., 1984. Role of tectonic denudation in warping an uplift of low-angle normal faults. Geology 12, 95-98. doi:10.1130/0091-7613(1984)12<95: ROTDIW>2.0.CO;2.

Spencer, J. E., Reynolds, S. J., 1986. Some aspects of the middle Tertiary tectonics of Arizona and southeastern California. In: Frontiers in geology and ore deposits of Arizona and the Southwest. Edited by Barbara Beatty \& P. A. K. Wilkinson. Arizona Geological Society Digest, XVI, 102-107.

Spencer J. E., Reynolds, S.J., 1990. Relationship between Mesozoic and Cenozoic tectonic features in west central Arizona and adjacent Southeastern California. Journal of Geophysical Research 9, 5, 539-555.

Stübner, K., Ratschbacher, L., Rutte, D., Stanek, K., Minaev, V., Wiesinger,M., Gloaguen, R., Project TIPAGE members, 2013. The giant Shakhdara migmatitic gneiss dome, Pamir, India-Asia collision zone: 1. Geometry and kinematics, Tectonics 32, 948-979. doi:10.1002/tect.20057.

Taylor, B., Weiss, J. R., Goodliffe, A. M., Sachpazi, M., Laigle M., Hirn, A., 2011. The structures, stratigraphy and evolution of the Gulf of Corinth rift, Greece. Geophysical Journal International 185, 1189-1219.

Tirel, C., Brun, J.-P., Burov, E., 2004a. Thermomechanical modeling of extensional gneiss domes, in Whitney, D.L., Teyssier, C., and Siddoway, C.S., eds., Gneiss Domes in Orogeny: Geological Society of America Special Paper 380, 67-78.

Tirel, C., Gueydan, F., Tiberi, C., Brun, J.-P., 2004b. Aegean crustal thickness inferred from gravity inversion: Geodynamical implications. Earth and Planetary Science Letters 228, 267-280.

Tirel, C., Brun, J.-P., Sokoutis, D., 2006. Extension of thickened and hot lithospheres: Inferences from laboratory modeling. Tectonics 25, TC1005. doi :10.1029/2005TC001804. Tirel, C., Brun, J.-P., Burov, E., 2008. Dynamics and structural development of metamorphic core complexes. Journal of Geophysical Research 113, B04403. doi :10.1029/2005JB003694.

Tirel, C., Gautier, P., Van Hinsbergen, D. J. J. Wortel, M. J. R., 2009. Sequential development of interfering metamorphic core complexes: numerical experiments and comparison with the Cyclades, Greece In Van Hinsbergen, D. J. J., Edwards, M. A. \& Govers, R. (eds) Collision and Collapse at the Africa-Arabia-Eurasia Subduction Zone. 
The Geological Society Special Publications 311, 257-292. doi: 10.1144/SP311.10 0305$8719 / 09 /$

Tirel, C., Brun, J.-P., Burov E., Wortel, M.J.R. and Lebedev, S., 2013. A plate tectonics oddity: Caterpillar-walk exhumation of subducted continental crust. Geology 41, 555558. Data Repository item 2013155 | doi :10.1130/G33862.1

Tubía, J., Cuevas, J., Ibarguchi, J.G., 1997. Sequential development of the metamorphic aureole beneath the Ronda peridotites and its bearing on the tectonic evolution of the Betic Cordillera. Tectonophysics 279, 227-252.

Tucholke, B.E., Lin, J., 1994. A geological model for the structure of ridge segments defining metamorphic core complexes on the Mid-Atlantic Ridge. Journal of Geophysical Research 99, 11,937-11,958. doi :10.1029/94JB00338.

Tucholke, B.E., Lin, J., Kleinrock, M., 1998. Megamullions and mullion structure defining oceanic core complexes on the Mid-Atlantic Ridge. Journal of Geophysical Research 103, 9857-9866. doi :10.1029/98JB00167.

Twiss, R.J., Moore, E.M., 2007. Structural Geology, 2nd ed., 736 p.

Wang, K., E Burov, E., Gumiaux, C., Chen, Y., Lu, G., Mezri, L., Zhao, L., 2015. Formation of metamorphic core complexes in non-over-thickened continental crust: A case study of Liaodong Peninsula (East Asia). Lithos 238, 86-100.

Watts, A.B., 2012. Models for the evolution of passive margins. In: Roberts, D.G., Bally, A.W.(eds) Regional geology and tectonics: phanerozoic rift systems and sedimentary basins. Elsevier, Amsterdam, 33-57. doi :10.1016/B978-0-444-56356-9.00002-X

Wdowinski, S., Axen, G.J., 1992. Isostatic rebound due to tectonic denudation: A viscous flow model of a layered lithosphere. Tectonics 11, 303-315, doi: 10.1029/91TC02341.

Weinberg, R. F., Regenauer - Lieb, K., Rosenbaum, G., 2007. Mantle detachments and the break - up of cold continental crust. Geology 35, 1035-1038. doi :10.1130/G23918A.1.

Wells, M. L., Allmendinger, R. W., 1990. An early history of pure shear in the upper plate of the Raft River metamorphic core complex: Black Pine Mountains, southern Idaho. Journal of Structural Geology 12, 851-867.

Wernicke, B., 1981. Low-angle normal faults in the Basin and Range Province-Nappe tectonics in an extending orogen. Nature 291, 645-648. doi :10.1038 /291645a0.

Wernicke, B., 1985. Uniform-sense normal simple shear of the continental lithosphere. Canadian Journal of Earth Sciences 22, 108-125. doi :10.1139/e85-009. 
Wernicke, B., 1990. The fluid crustal layer and its implications for continental dynamics, in Salisbury, M., ed., Exposed cross sections of the continental crust: Dordrecht, Netherlands, NATO Advanced Studies Institute, Kluwer Academic Publishers, D. Reidel, $509-544$.

Wernicke, B., 2009. The detachment era (1977-1982) and its role in revolutionizing continental tectonics. From: Ring, U. and Wernicke, B., (eds) Extending a Continent: Architecture, Rheology and Heat Budget. Geological Society Special Publications 321, 18. doi: 10.1144/SP321.1 0305-8719/09/\$15.00

Wernicke, B.P., Christiansen, R.L., England, P.C., Sonder, L.J., 1987. Tectonomagmatic evolution of Cenozoic extension in the North American Cordillera, in : Continental Extensional Tectonics, M.P. Coward, J.F. Dewey and P.L. Hancock, eds., Geological Society Special Publications 28, 203-221.

Wernicke, B., Axen, G.J., 1988. On the role of isostasy in the evolution of normal fault systems. Geology 16, 848-851. doi:10.1130/0091-7613(1988)016<0848: OTROII>2.3.CO;2.

Whitney, D.L., Teyssier, C., Rey, P., Buck, W.R., 2013. Continental and oceanic core complexes. Geological Society of America Bulletin 125, 273-298.

Wijns, C., Weinberg, R., Gessner, K., Moresi, L., 2005. Mode of crustal extension determined by rheological layering. Earth and Planetary Science Letters 236, 120-134. doi:10.1016/j.eps1.2005.05.030.

Wortel, M.J.R., Spakman, W., 2000. Subduction and slab detachment in the Mediterranean-Carpathian region. Science 290: 1910-1917. doi:10.1126/ science.290.5498.1910.

Wu, G., and Lavier, L.L., Choi, E., 2015 Modes of continental extension in a crustal wedge, Earth Planetary Science Letters 421, 89-97. doi:10.1016/j.eps1.2015.04.005.

$\mathrm{Wu}, \mathrm{G}$., and Lavier, L.L., 2016. The effects of lower crustal strength and preexisting midcrustal shear zones on the formation of continental core complexes and low-angle normal faults, Tectonics 35. doi:10.1002/2016TC004245.

\section{Tables captions}

Tab.1. Analogue and numerical models of core complexes. See discussion in the text. 
Tab.2. Analogue and numerical models of lithosphere extension leading to mantle exhumation at passive margins. The symmetry or asymmetry mentioned here concerns the structure of the rift structure not the symmetry or asymmetry of applied boundary displacements. See discussion in the text.

\section{Figure Captions}

Fig. 1. The three types of extensional structures of the continental or oceanic lithosphere in which deep ductile rocks from crust or mantle are exhumed.

Fig. 2. Conceptual models of large-scale low-angle detachments. a) Simple shear detachment at lithosphere scale (modified from Wernicke, 1981; 1985). b) Model of warping and uplift of a low-angle detachment fault resulting from isostatic uplift of the footwall in response of tectonic denudation (modified from Spencer, 1984). c) Model of successive low-angle detachments (1,2 and 3) in the brittle crust connected to a horizontal shear zone in the upper part of the ductile crust leading to the exhumation of the ductile crust (modified from Reynolds and Lister, 1990).

Fig. 3. Conceptual models of "rolling hinge" development of detachments. a) Model sustained by thin plate flexure modeling (modified from Buck, 1988). b) Model designed from field observations and measurements (modified from Wernicke and Axen, 1988). c) Asymmetric growth of a core complex resulting from a rolling hinge process (modified from Brun and Van Den Driessche, 1994).

Fig.4. Structure of a core complex resulting from a rolling hinge process (modified from Brun and Van Den Driessche, 1994). a) Three-dimensional sketch. b) Structure of the ductile part of the core complex as defined by foliation trajectories. c) Deformation processes within the ductile core and the detachment zone.

Fig.5. (a-f) Numerical models of continental lithosphere deformation showing the relative effects of temperature (for initial Moho temperatures $\mathrm{T}_{\mathrm{m}}=356^{\circ} \mathrm{C}, 482^{\circ} \mathrm{C}$ and $753^{\circ} \mathrm{C}$ ) and velocity of extension (for $\mathrm{V}=1 \mathrm{~cm} / \mathrm{y}$ and $1 \mathrm{~mm} / \mathrm{y}$ ). (g-h) Strength profiles of models. (modified from Gueydan et al., 2008). In a, b, d and e, the structures are of "narrow rift-type" and in c and d of "wide rift-type". 
Fig.6. Two centrifuge analogue models of extension with similar brittle-ductile layering (a) with (wide rift-type) and (b) without (core complex-type) a low viscosity anomaly (Viscosity contrast $\mu_{\text {layer }} / \mu_{\text {layer }}=15$ ) located below the brittle-ductile interface (modified from Brun et al., 1994).

Fig.7. Core complex versus passive margin modes of extension as functions of crustal thickness $\left(\mathrm{C}_{\text {thick }}\right)$ and mantle heat flow (MHF) (modified from Tirel et al., 2008). a) Computed numerical models with corresponding Moho temperatures. b) Domains of core complex and passive margin modes of extension with diagnostic features. The boundary between the two domains corresponds to Moho temperatures $\mathrm{T}_{\mathrm{M}}>800^{\circ} \mathrm{C}$ and ductile crust viscosity $\mathrm{V}_{\mathrm{CI}}<10^{20}$ Pa.s.

Fig.8. Analogue modeling of core complex development in a two-layer brittle-ductile system (modified from Brun et al., 1994). a) Experimental setting. b to d) Sections of models for increasing amounts of extension. e) General model of core complex and detachment development summarizing the process observed in analogue models.

Fig.9. Cross-sections of: a) the Snake Range Core Complex (modified from Miller et al., 1999) and b) the Buckskin-Rawhide Core Complex (modified from Spencer and Reynolds, 1990)

Fig.10. Numerical modeling of core complex development at lithosphere scale (modified from Tirel et al., 2008). a) Model geometry and velocity boundary conditions. b to d) Sections of models for increasing amount of extension. Each panel presents the model structure and the $400^{\circ} \mathrm{C}$ and $600^{\circ} \mathrm{C}$ isotherms (top section), the strain rate (middle section) and the pattern of total shear strain (down section). Structure, strain rate and total shear strain representations correspond to those parts of the computed numerical mesh where most of deformation is located and not to the entire initial model.

Fig.11. Four-stage deformation pattern of the core complex model of Figure 10 (from sections of total shear strain) showing the progressive development of shear zones in the ductile layer. The evolution shows two main stages: i) "Initiation" corresponding to the necking of the brittle crust and ii) the "amplification" corresponding to the core complex growth. The first stage ends when the ductile crust reaches the surface and the detachment zone initiates. 
Fig.12. Large-scale recumbent folding in the ductile crust of the core complex model of Figure 10 (drawn from model structure and $400^{\circ} \mathrm{C}$ isotherm as a proxy of the transient brittleductile transition).

Fig.13. Cross section of the Corinth Rift (Greece). Geological cross-section at rift center modified from Taylor et al., (2011). Seismicity and focal mechanisms of earthquakes modified from Rigo et al., (1996). See location of cross-section in Fig. 14a.

Fig.14. Core complexes in the Aegean domain (Eastern Mediterranean) (modified after Kydonakis et al., 2015a). a) Simplified geological map showing the three main continental blocks of Rhodopia, Pelagonia and Adria separated by the Vardar and Pindos suture zones. The two domains of core complexes are outlined by vertical red hatching: Northern Rhodope Core Complex (NRCC) and Southern Rhodope Core Complex (SRCC) in the North and Central Cyclades Core Complex (CCCC) in central Aegean. b) Three lithosphere-scale sections showing the present-day relation (down) between the three main continental blocks and the Hellenic slab and the restoration of displacement and structures in Lower Miocene (middle) and Eocene (top). c) Cross-section of the northern part of the Aegean domain showing the geometry of the SRCC and NRCC and associated detachments.

Fig.15. Geometry of mantle core complexes at oceanic spreading ridges. a) At slow spreading rate in the Mid-Atlantic Ridge (MAR) (From seismic section; modified after Canales et al., 2004). b) At ultra-slow spreading rate in the South Indian Ridge (SWIR) (Sketch of the flipflop model of continuous exhumation of mantle rocks; modified after Sauter et al., 2013).

Fig.16. Analogue models of rifting in a four-layer brittle-ductile lithosphere (modified after Brun and Beslier, 1996). Bc: Brittle crust; Dc: Ductile crust; Bm: Brittle mantle; Dm: Ductile mantle. Arrows correspond to the applied boundary displacement. a) Model stretched up the exhumation of ductile mantle. b) Model with stretching amount lower than for model-a (vertical passive markers show the sense of shear in the ductile layers). c) Restoration of model-b showing the conjugate pattern of shear zones in ductile crust and mantle.

Fig.17. General deformation model deduced from analogue model (modified from Brun and Beslier, 1996). The evolution shows two main stages: i) "Initiation" corresponding to the necking of the whole crust plus high-strength mantle and ii) the "amplification" corresponding to the exhumation of mantle until volcanic crust is created. The initiation stage ends when the ductile continental mantle reaches the surface. During the amplification stage 
the exhumation of mantle could likely occur through successive rolling hinge detachment faults as observed in ultra-slow spreading ridges (Fig. 15b). The ductile crust shear zones (LCSZ) correspond to décollements (i.e. layer-parallel shear) between the upper brittle crust and the high strength sub-Moho mantle in which strain intensity increases toward the rift axis. As the mantle shear zones (MSZ), which accommodate mantle ascent and exhumation since the initiation, continuously migrate toward the rift axis (b to e) there is no permanent detachment fault at mantle level.

Fig.18. Brittle and ductile deformation pattern at the tip of a passive margin (Carratraca sector of the Ronda peridotite massif; Western Betics; South Spain) (modified after Frasca et al., 2016). a) Geological map showing the senses of shear in the brittle/ductile crust and ductile crust and mantle. b) NS-trending cross-section (see location in a) showing the three tilted blocks of Agua, La Robla and Alozaina. c) Variation of the ductile crust thickness from Agua to Alozaina.

Fig.19. Diagram summarizing similarities and differences, in terms of geometry, structures and rheology, between the three types of extensional structures in which the ductile crust or mantle is exhumed. 


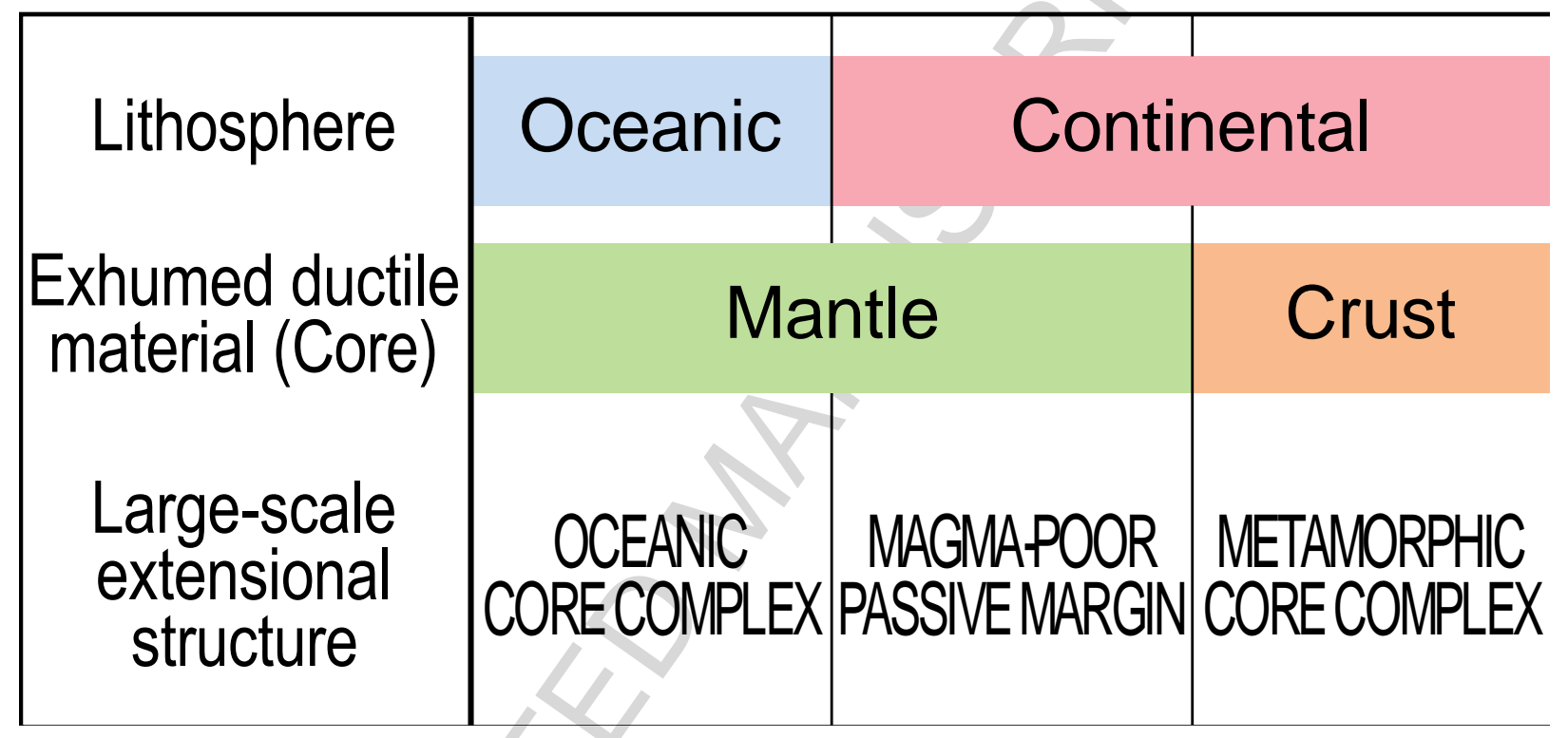

Fig. 1. The three types of extensional structures of the continental or oceanic lithosphere in which deep ductile rocks from crust or mantle are exhumed. 


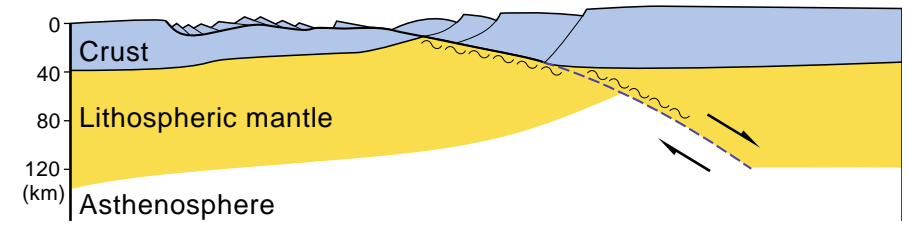

a
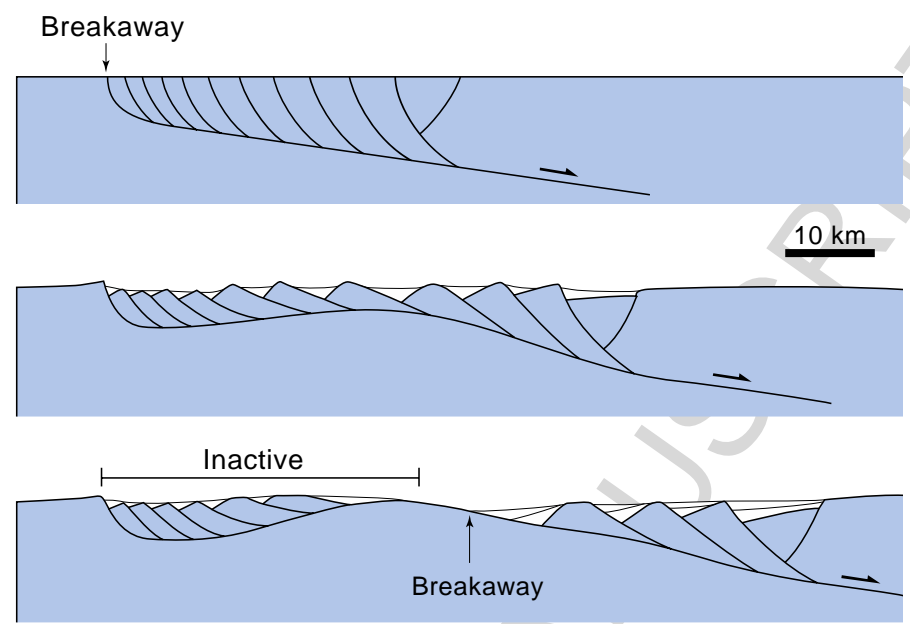

b

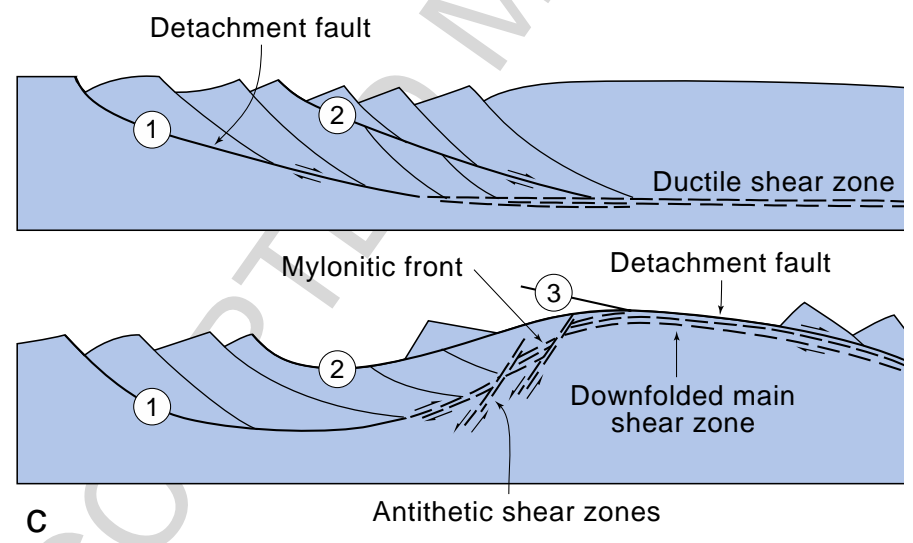

Fig. 2. Conceptual models of large-scale low-angle detachments. a) Simple shear detachment at lithosphere scale (modified from from Wernicke, 1981; 1985). b) Model of warping and uplift of a low-angle detachment fault resulting from isostatic uplift of the footwall in response of tectonic denudation (modified from Spencer, 1984). c) Model of successive lowangle detachments $(1,2$ and 3$)$ in the brittle crust connected to a horizontal shear zone in the upper part of the ductile crust leading to the exhumation of the ductile crust (modified from Reynolds and Lister, 1990). 

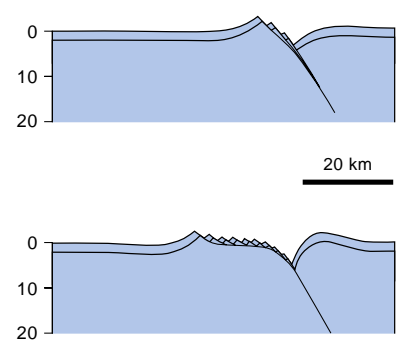

20

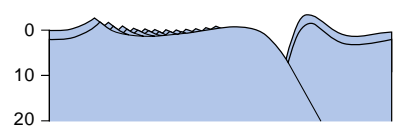

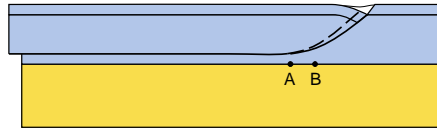
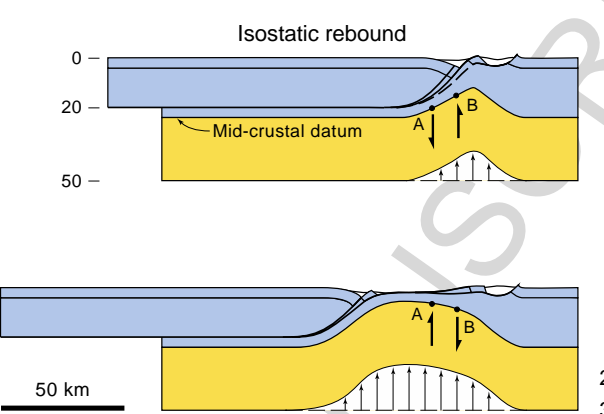

b

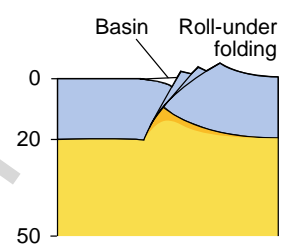

- Active - Inactive
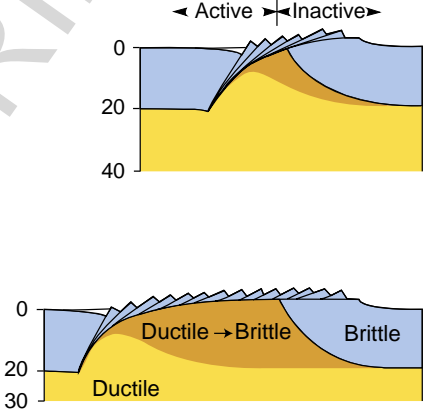

C

Fig. 3. Conceptual models of "rolling hinge" development of detachments. a) Model sustained by thin plate flexure modeling (modified from Buck, 1988). b) Model designed from field observations and measurements (modified from Wernicke and Axen, 1988). c) Asymmetric growth of a core complex resulting from a rolling hinge process (modified from Brun and Van Den Driessche, 1994). 


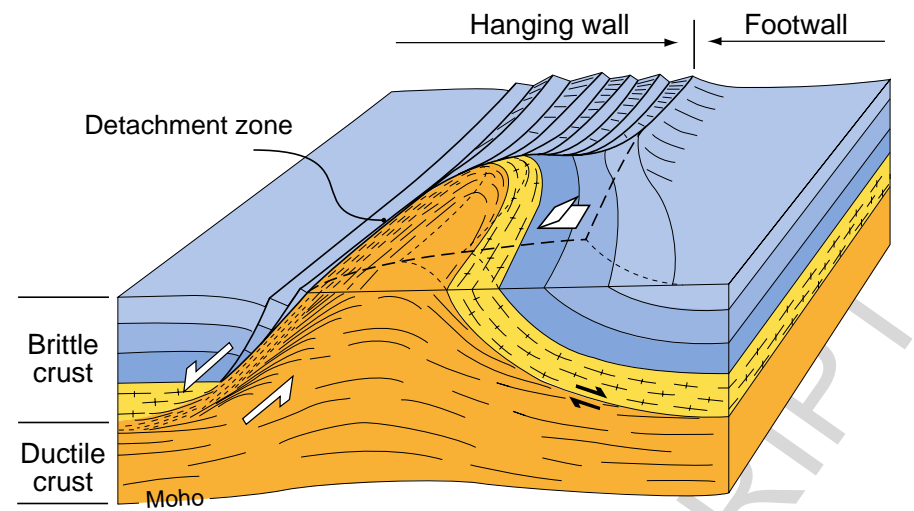

a

$30 \mathrm{~km}$

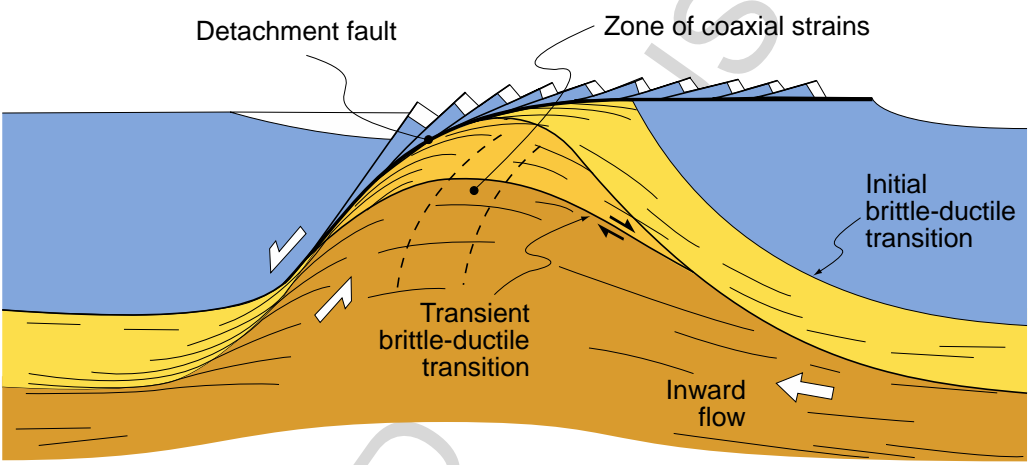

b

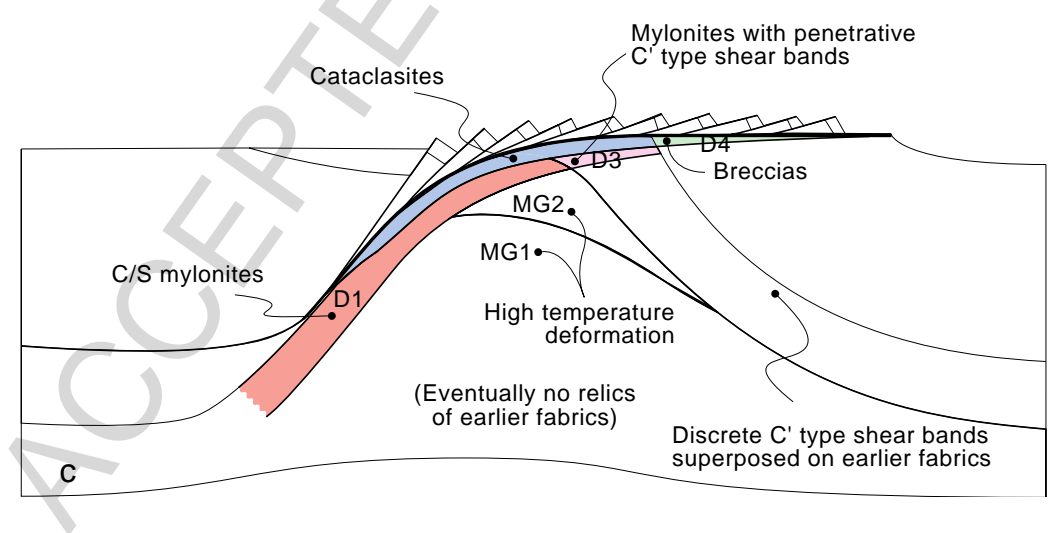

Fig.4. Structure of a core complex resulting from a rolling hinge process (modified from Brun and Van Den Driessche, 1994). a) Three-dimensional sketch. b) Structure of the ductile part of the core complex as defined by foliation trajectories. c) Deformation processes within the ductile core and the detachment zone. 
$V=1 \mathrm{~cm} / \mathrm{a}$

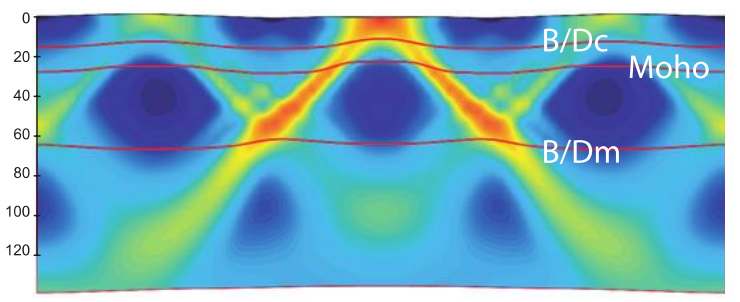

a
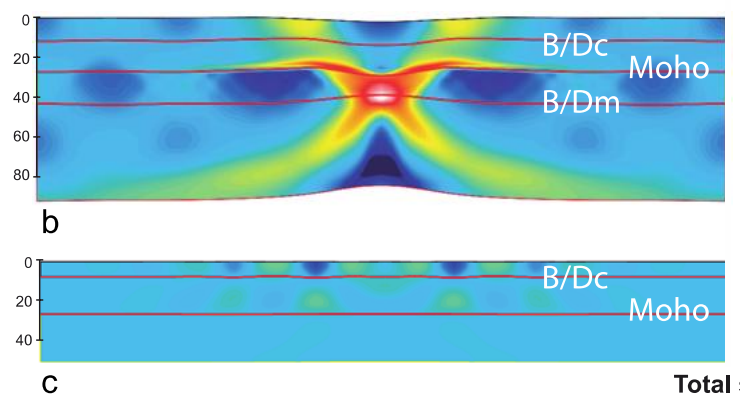

$40 \mathrm{~km}$ horizontal extension

(4Ma)
$\mathrm{T}_{\mathrm{M}}$
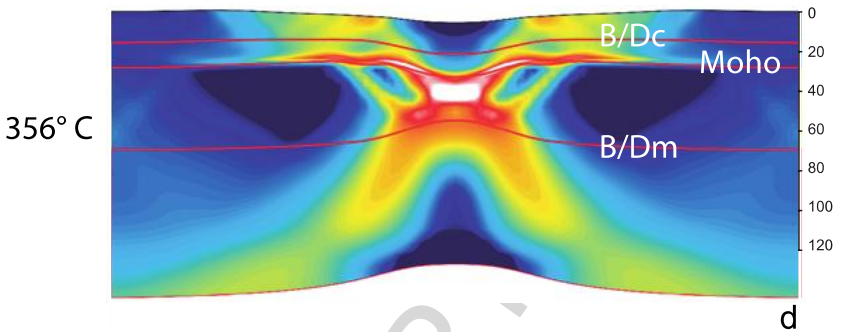

$482^{\circ} \mathrm{C}$

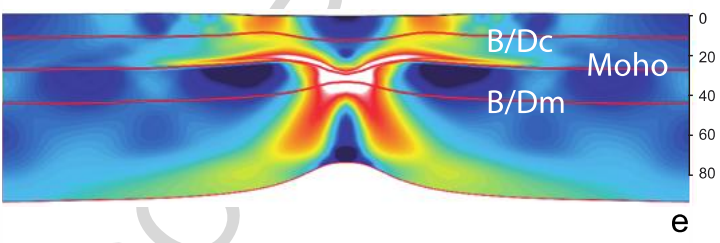

$753^{\circ} \mathrm{C}$

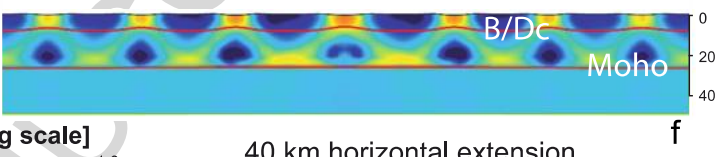

$40 \mathrm{~km}$ horizontal extension (40 Ma)

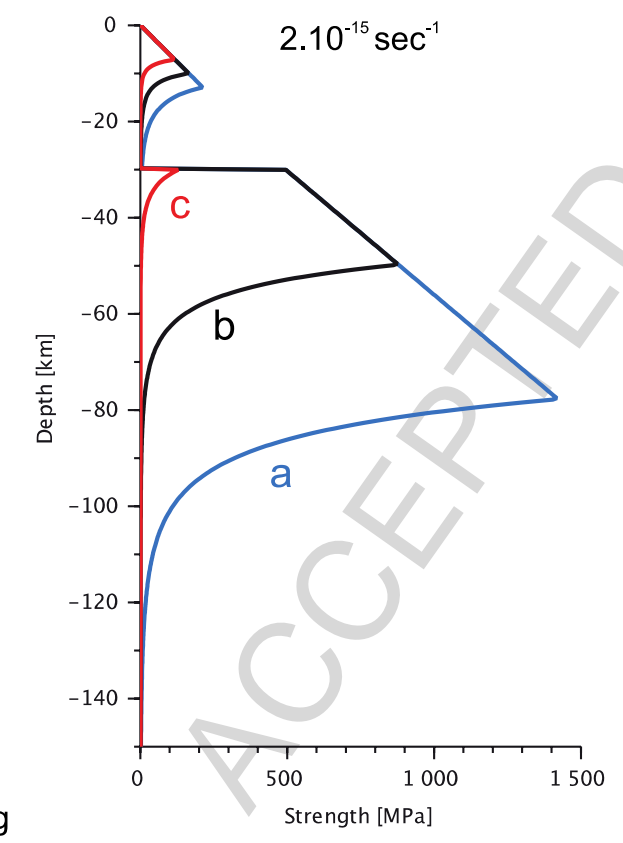

Strain rate

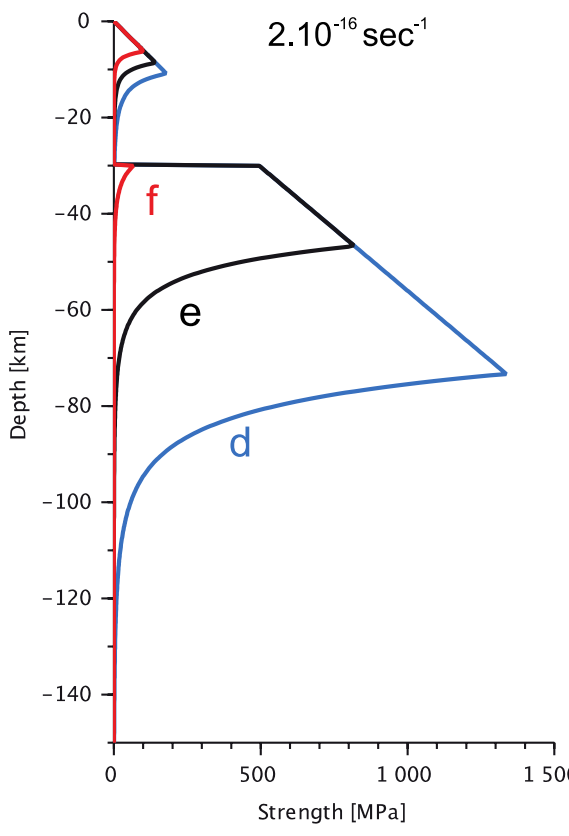

$\mathrm{h}$

Fig.5. (a-f) Numerical models of continental lithosphere deformation showing the relative effects of temperature (for initial Moho temperatures $\mathrm{T}_{\mathrm{m}}=356^{\circ} \mathrm{C}, 482^{\circ} \mathrm{C}$ and $753^{\circ} \mathrm{C}$ ) and velocity of extension (for $\mathrm{V}=1 \mathrm{~cm} / \mathrm{y}$ and $1 \mathrm{~mm} / \mathrm{y}$ ). (g-h) Strength profiles of models. (modified from Gueydan et al., 2008). In a, b, d and e, the structures are of "narrow rift-type" and in c and d of "wide rift-type". 

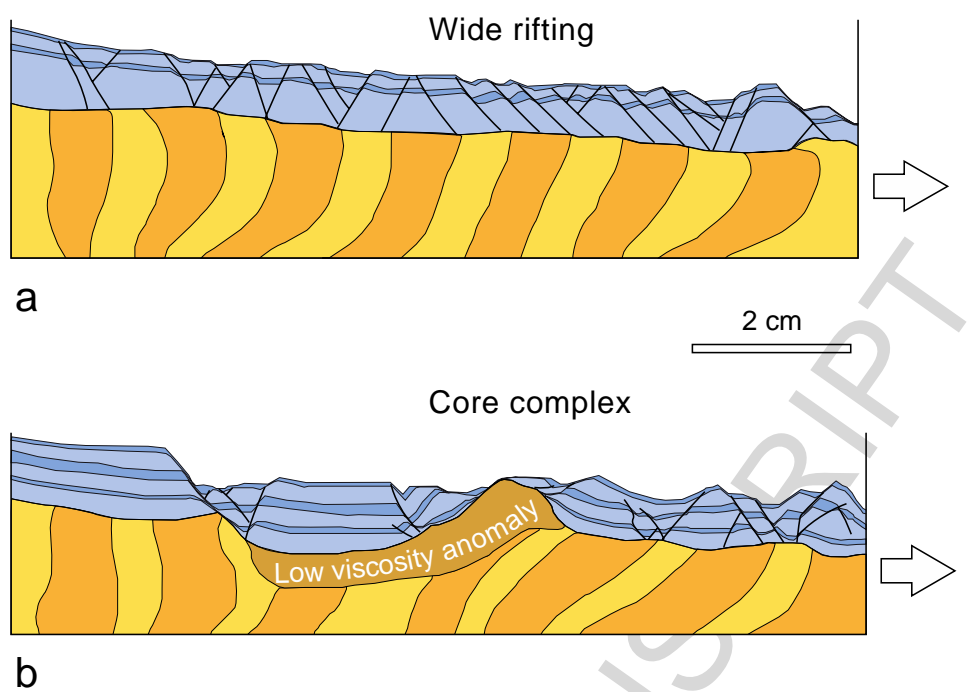

Fig.6. Two centrifuge analogue models of extension with similar brittle-ductile layering (a) with (wide rift-type) and (b) without (core complex-type) a low viscosity anomaly (Viscosity contrast $\mu_{\text {layer }} / \mu_{\text {layer }}=15$ ) located below the brittle-ductile interface (modified from Brun et al., 1994). 

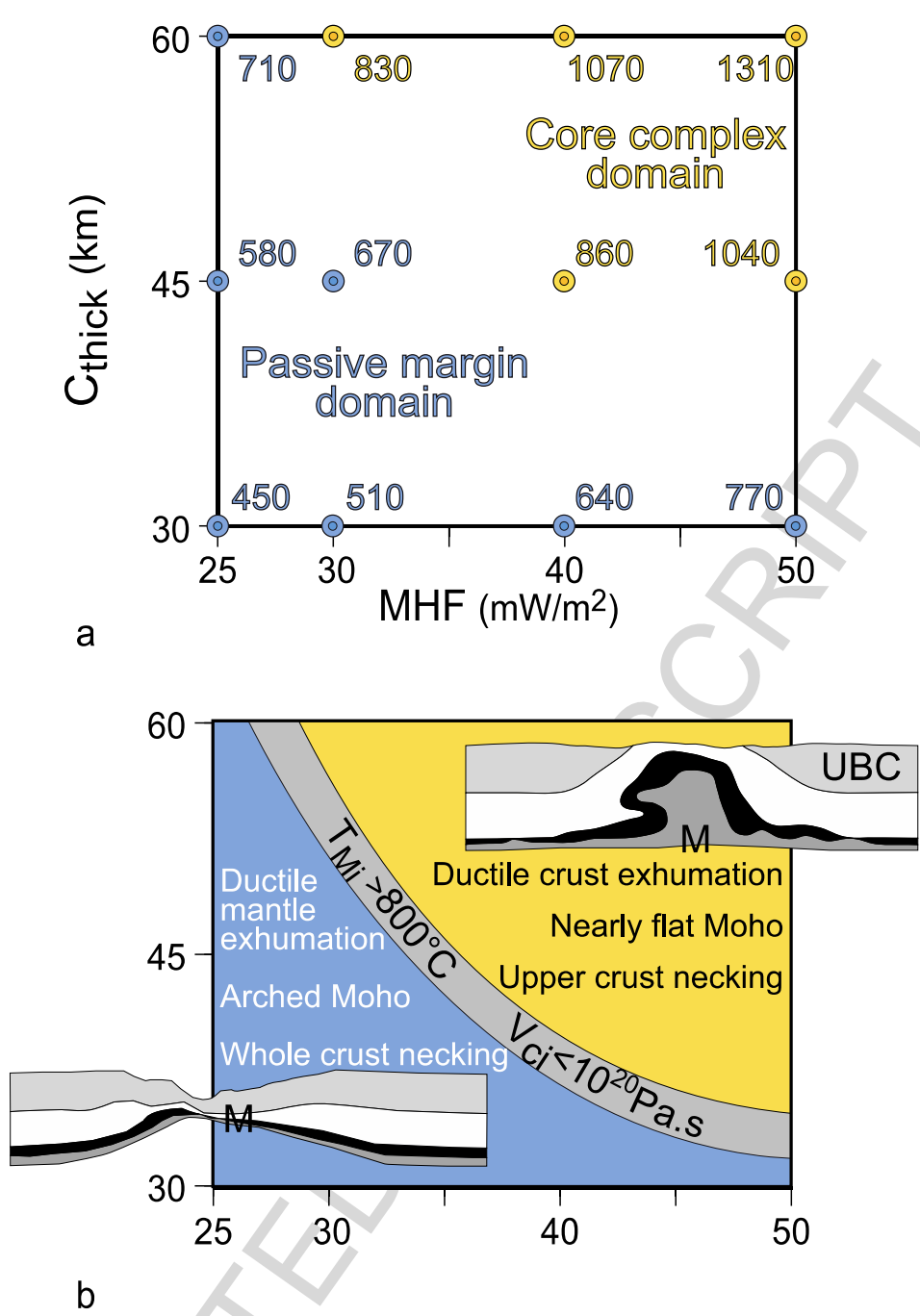

Fig.7. Core complex versus passive margin modes of extension as functions of crustal thickness $\left(\mathrm{C}_{\text {thick }}\right)$ and mantle heat flow (MHF) (modified from Tirel et al., 2008). a) Computed numerical models with corresponding Moho temperatures. b) Domains of core complex and passive margin modes of extension with diagnostic features. The boundary between the two domains correspond to Moho temperatures $\mathrm{T}_{\mathrm{M}}>800^{\circ} \mathrm{C}$ and ductile crust viscosity $\mathrm{V}_{\mathrm{CI}}<10^{20}$ Pa.s. 

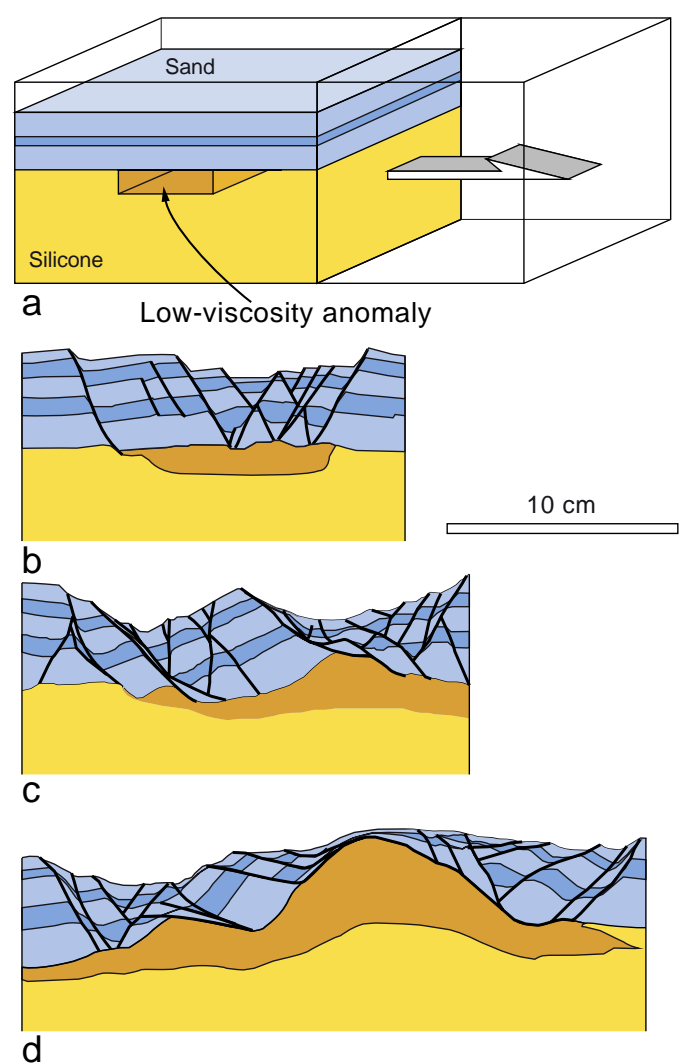
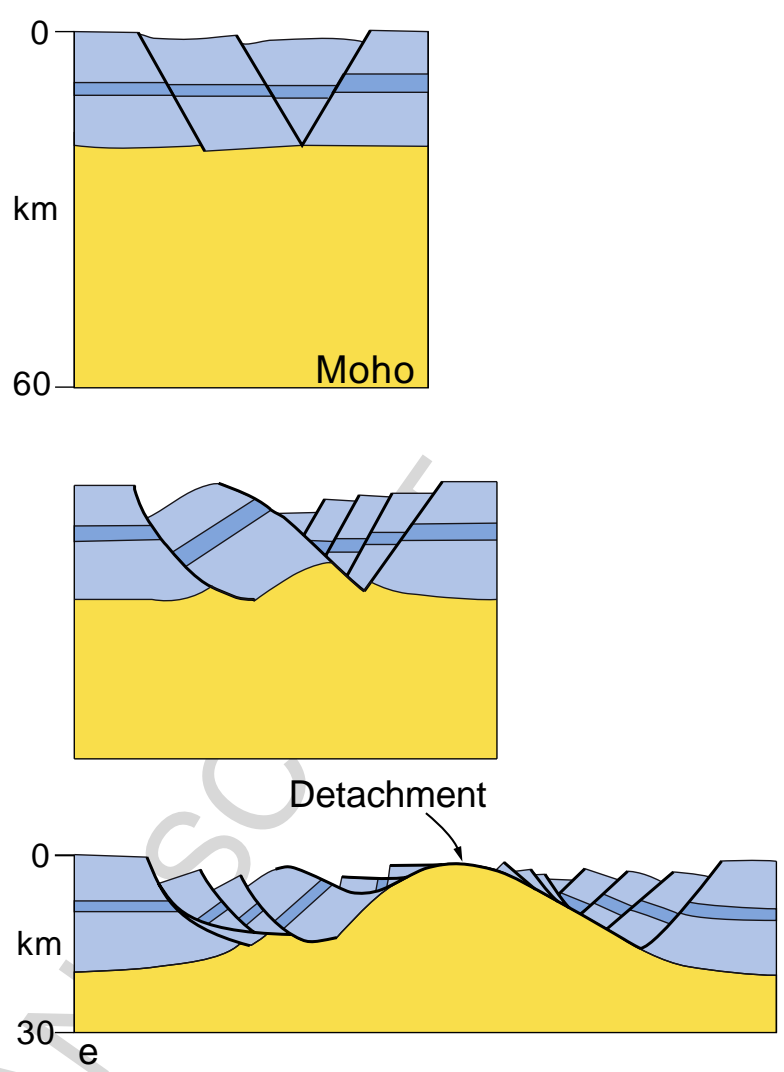

Fig.8. Analogue modeling of core complex development in a two-layer brittle-ductile system (modified from Brun et al., 1994). a) Experimental setting. b to d) Sections of models for increasing amounts of extension. e) General model of core complex and detachment development summarizing the process observed in analogue models. 

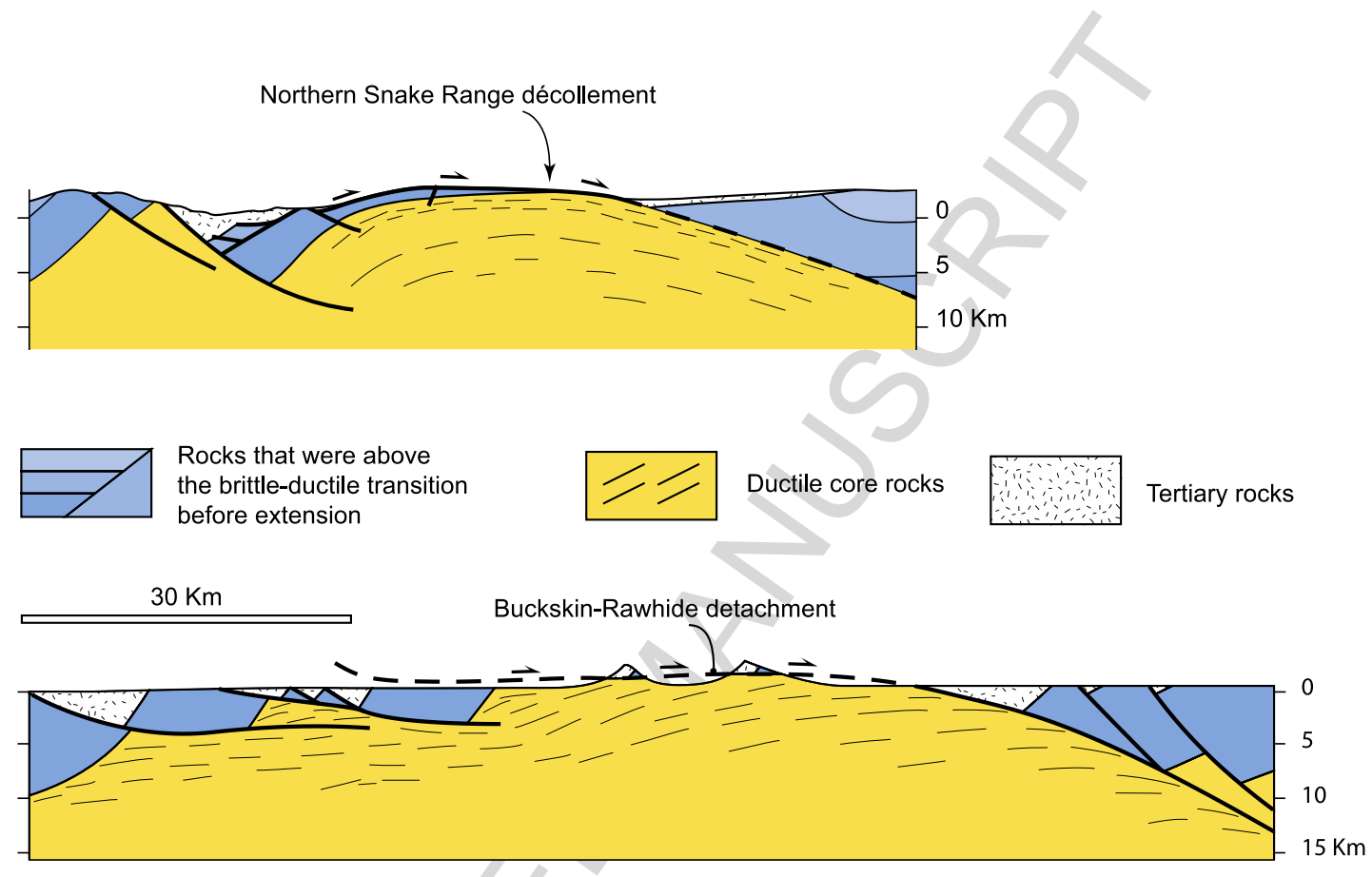

Fig.9. Cross-sections of: a) the Snake Range Core Complex (modified from Miller et al., 1999) and b) the Buckskin-Rawhide Core Complex (modified from Spencer and Reynolds, 1990) 


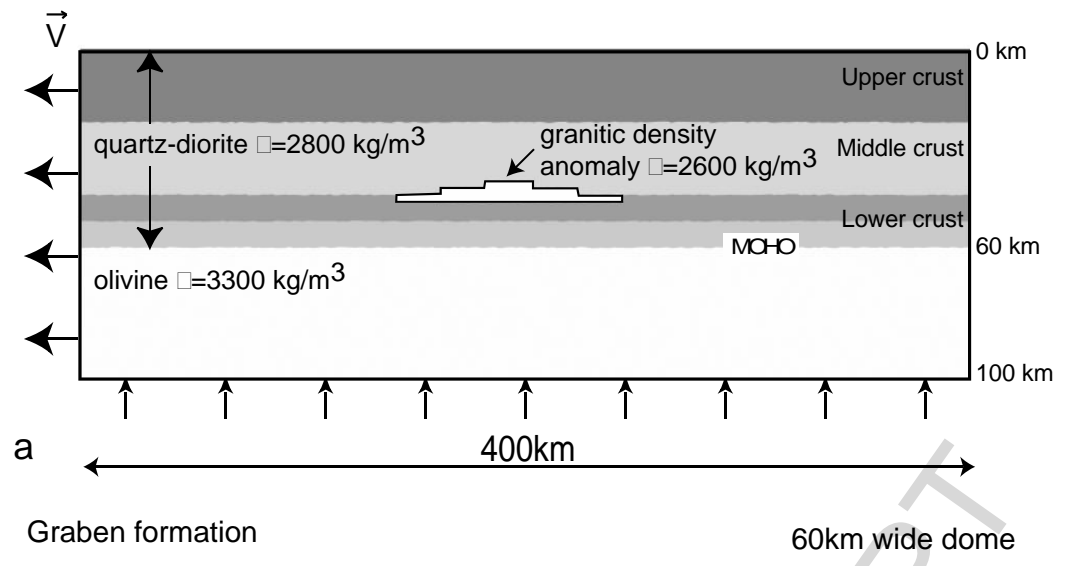

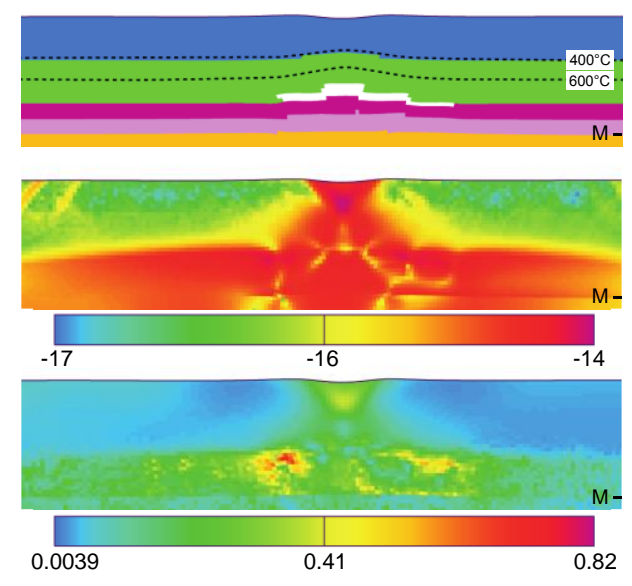

b

Onset of ductile crust exhumation (dome)
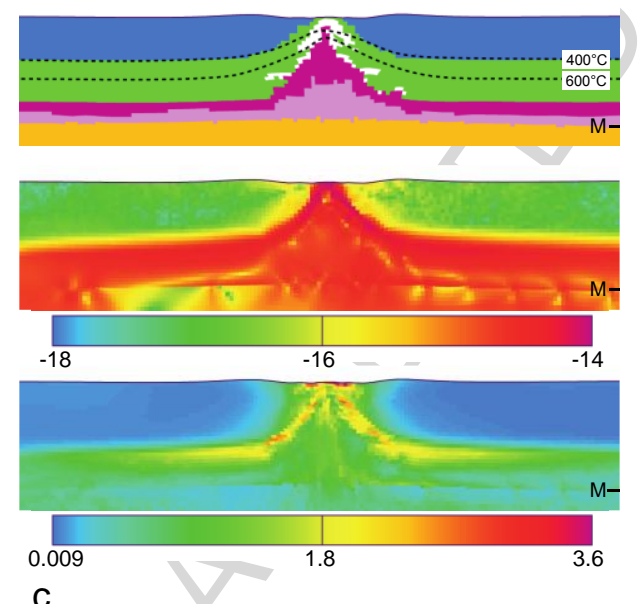
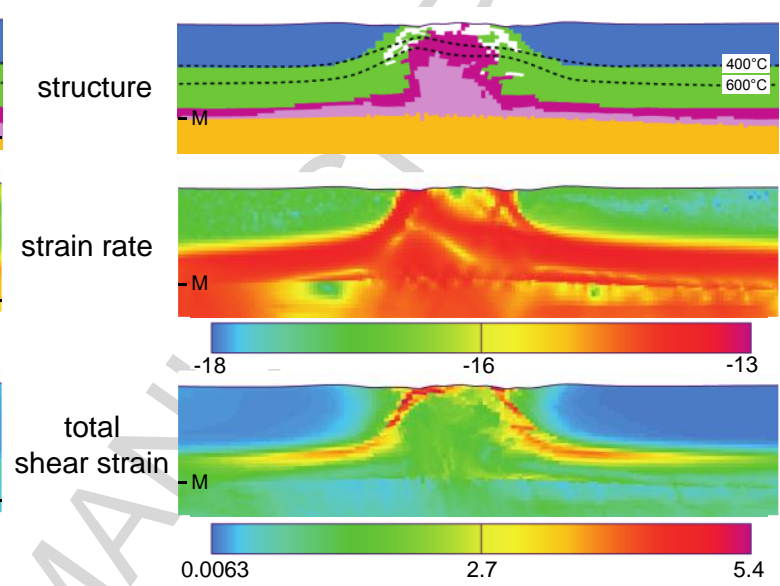

d

$150 \mathrm{~km}$ wide dome
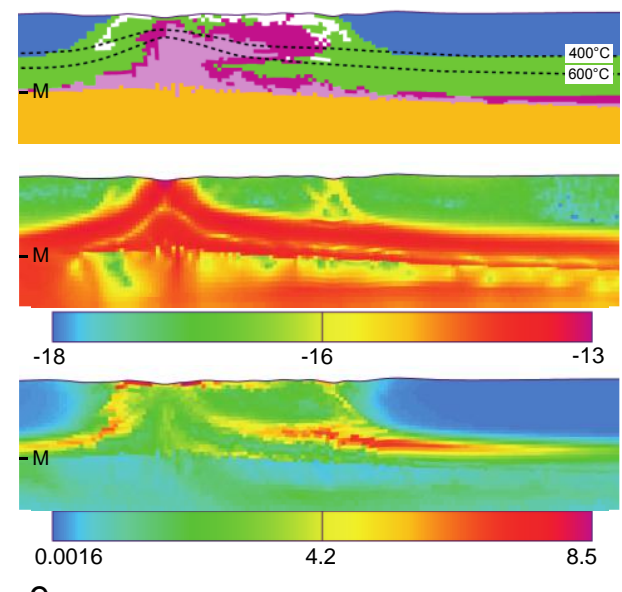

e

Fig.10. Numerical modeling of core complex development at lithosphere scale (modified from Tirel et al., 2008). a) Model geometry and velocity boundary conditions. b to d) Sections of models for increasing amount of extension. Each panel presents the model structure and the $400^{\circ} \mathrm{C}$ and $600^{\circ} \mathrm{C}$ isotherms (top section), the strain rate (middle section) and the pattern of total shear strain (down section). Structure, strain rate and total shear strain representations correspond to those parts of the computed numerical mesh where most of deformation is located and not to the entire initial model. 


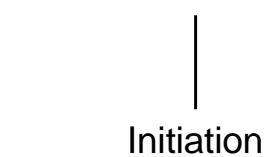

Brittle crust necking

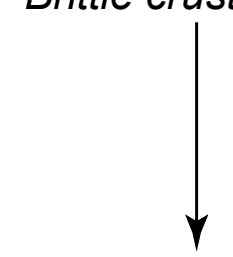

Ductile crust exhumation

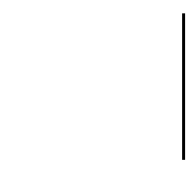

Amplification

Core complex growth

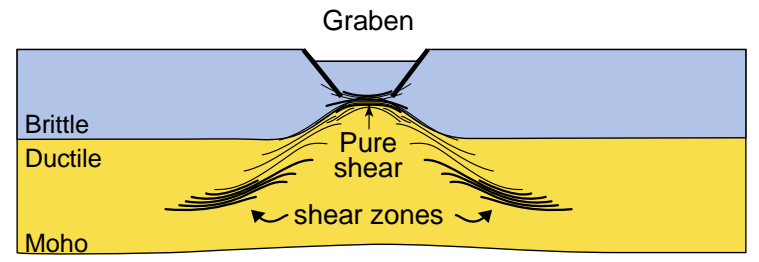

a

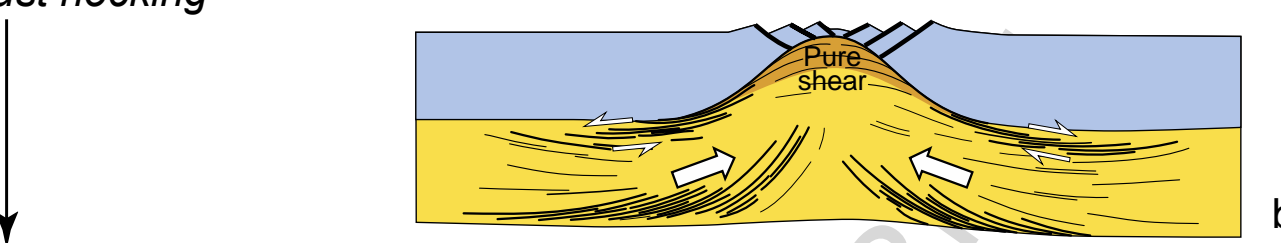

b

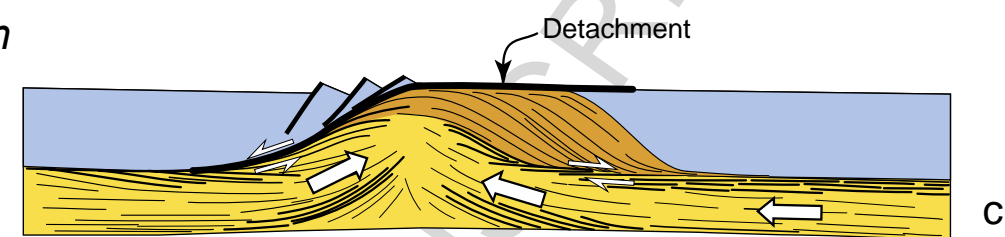

C

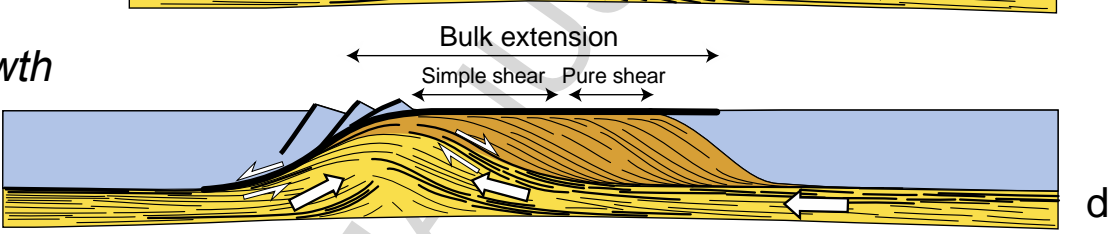

Fig.11. Four-stage deformation pattern of the core complex model of Figure 10 (from sections of total shear strain) showing the progressive development of shear zones in the ductile layer. The evolution shows two main stages: i) "Initiation" corresponding to the necking of the brittle crust and ii) the "amplification" corresponding to the core complex growth. The first stage ends when the ductile crust reaches the surface and the detachment zone initiates. 

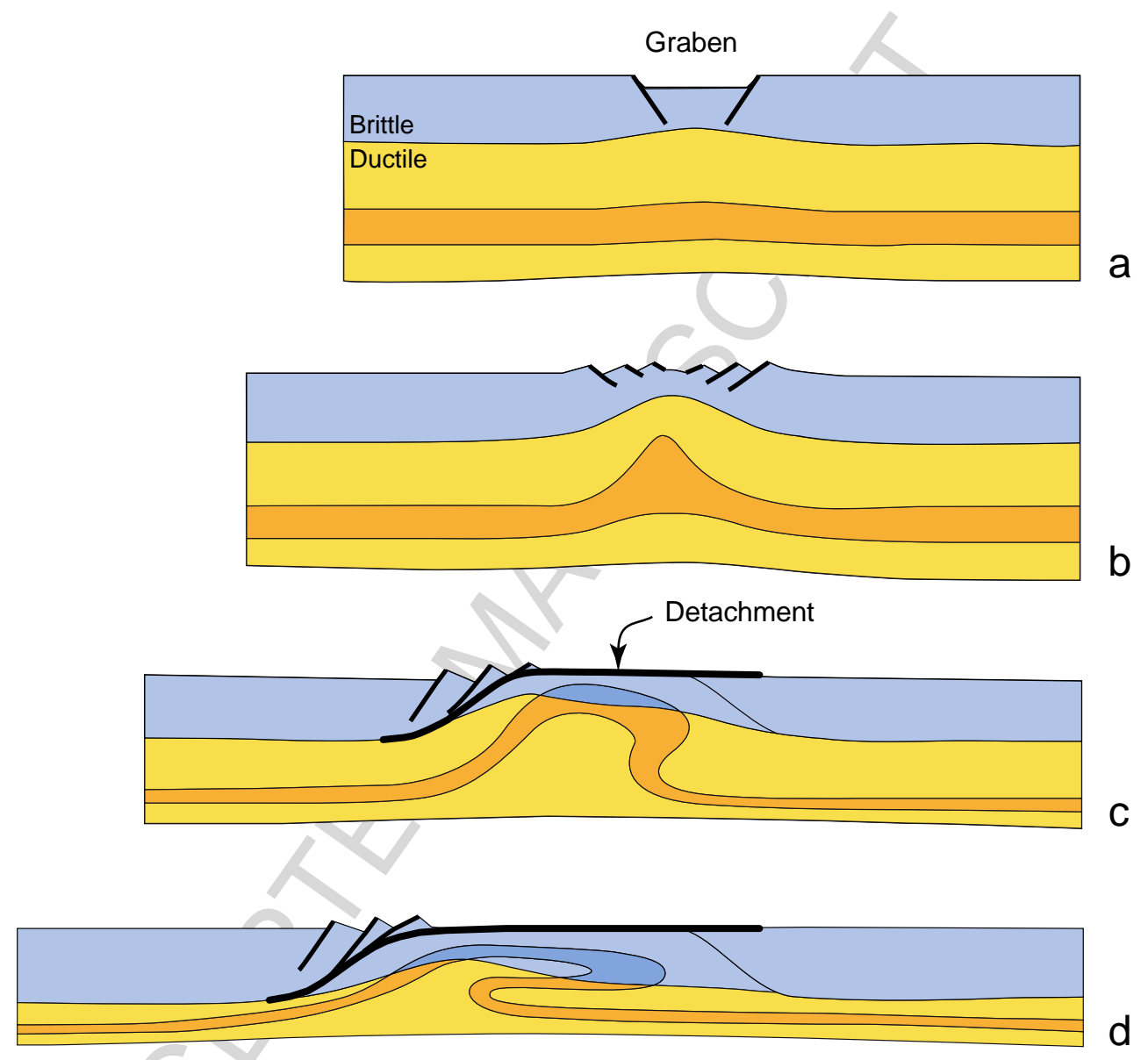

b

Fig.12. Large-scale recumbent folding in the ductile crust of the core complex model of Figure 10 (drawn from model structure and $400^{\circ} \mathrm{C}$ isotherm as a proxy of the transient brittleductile transition). 


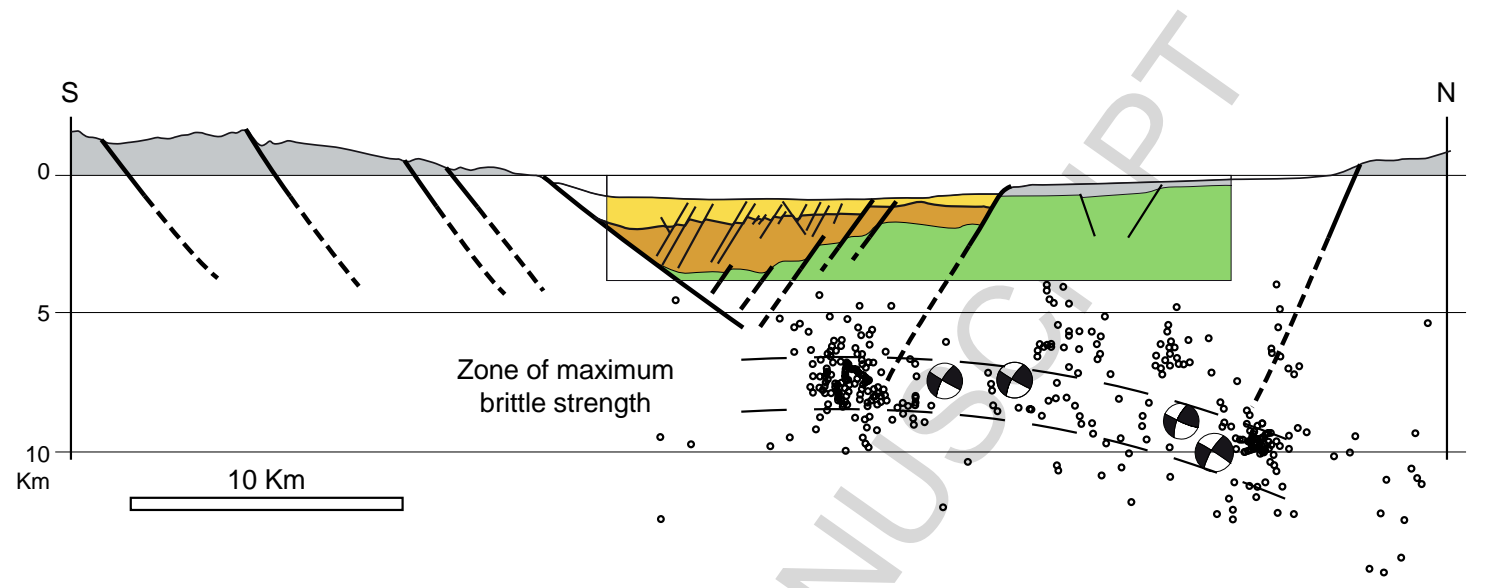

Fig.13. Cross section of the Corinth Rift (Greece). Geological cross-section at rift center modified from Taylor et al., (2011). Seismicity and focal mechanisms of earthquakes modified from Rigo et al., (1996). See location of cross-section in Fig. 14a. 

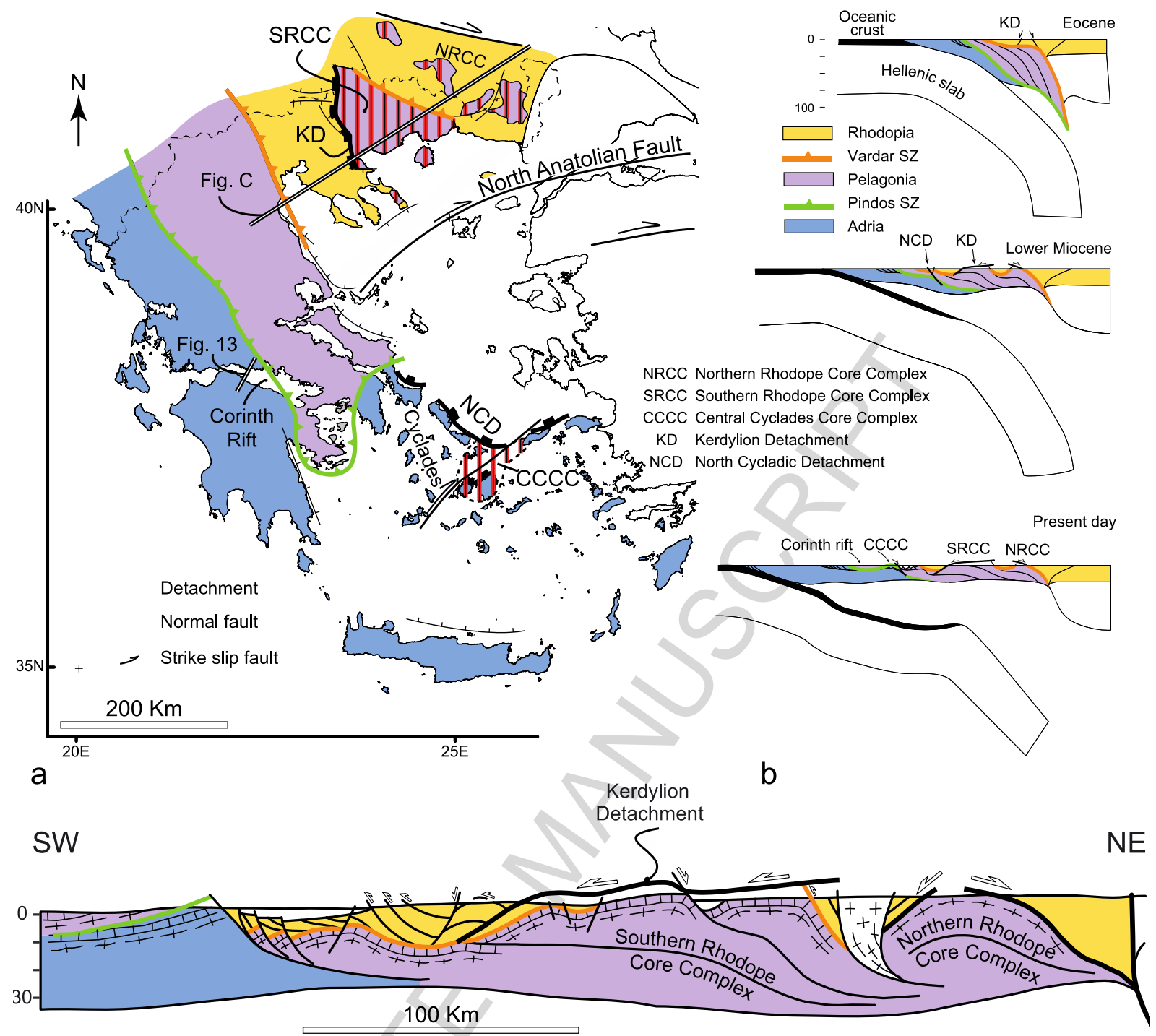

C

Fig.14. Core complexes in the Aegean domain (Eastern Mediterranean) (modified after Kydonakis et al., 2015a), a) Simplified geological map showing the three main continental blocks of Rhodopia, Pelagonia and Adria separated by the Vardar and Pindos suture zones. The two domains of core complexes are outlined by vertical red hatching: Northern Rhodope Core Complex (NRCC) and Southern Rhodope Core Complex (SRCC) in the North and Central Cyclades Core Complex (CCCC) in central Aegean. b) Three lithosphere-scale sections showing the present day relation (down) between the three main continental blocks and the Hellenic slab and the restoration of displacement and structures in Lower Miocene (middle) and Eocene (top). c) Cross-section of the northern part of the Aegean domain showing the geometry of the SRCC and NRCC and associated detachments. 

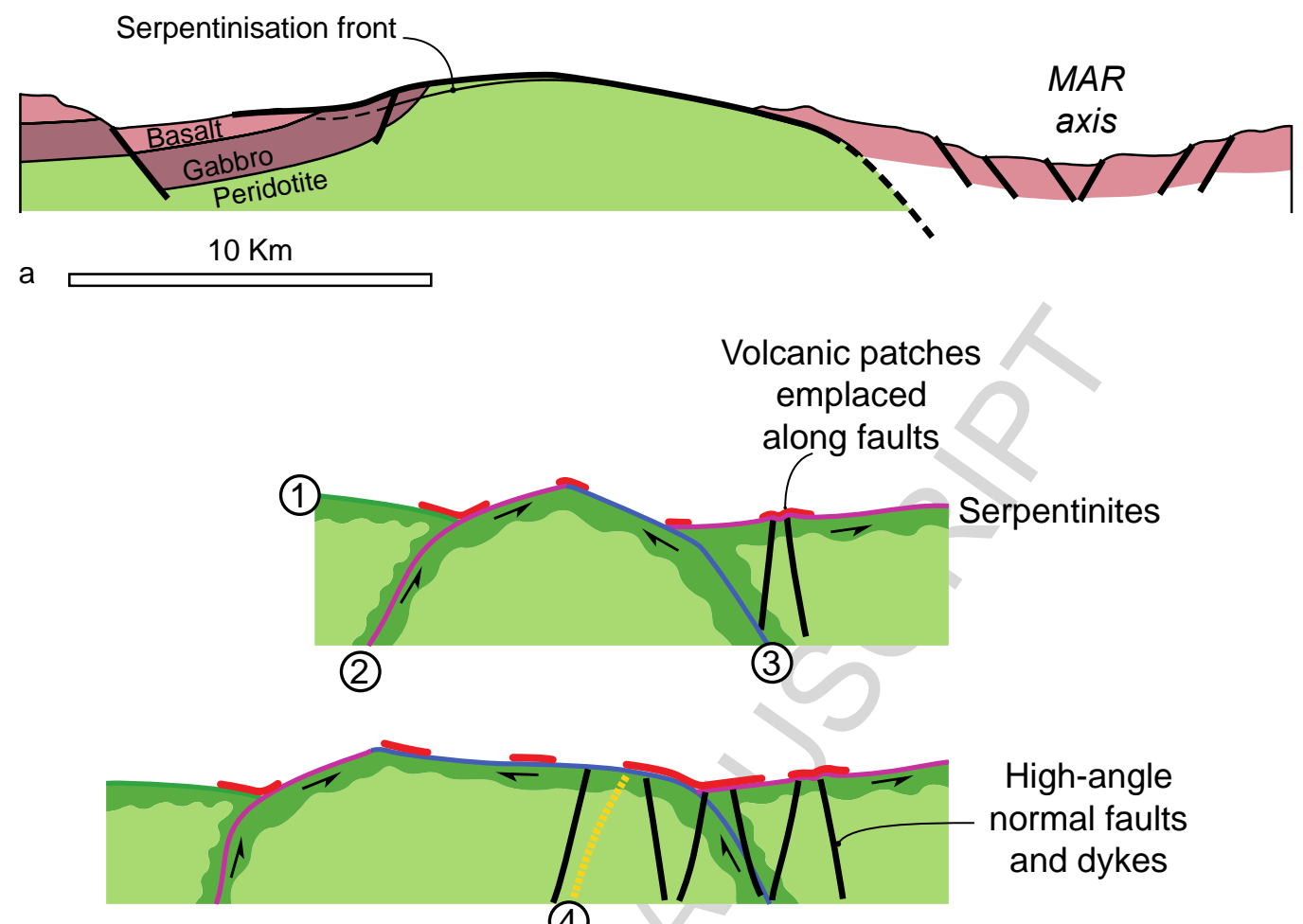

(4)

Tilted

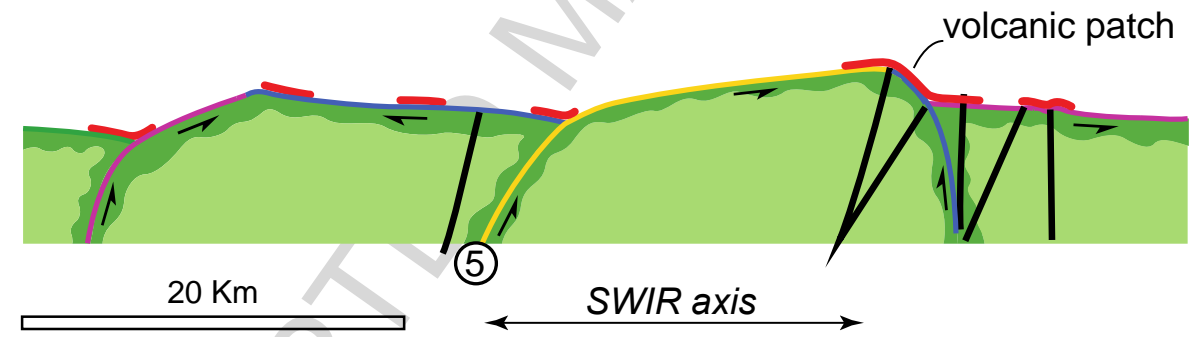

Fig.15. Geometry of mantle core complexes at oceanic spreading ridges. a) At slow spreading rate in the Mid-Atlantic Ridge (MAR) (From seismic section; modified after Canales et al 2004). b) At ultra-slow spreading rate in the South Indian Ridge (SWIR) (Sketch of the flipflop model of continuous exhumation of mantle rocks; modified after Sauter et al., 2013). 

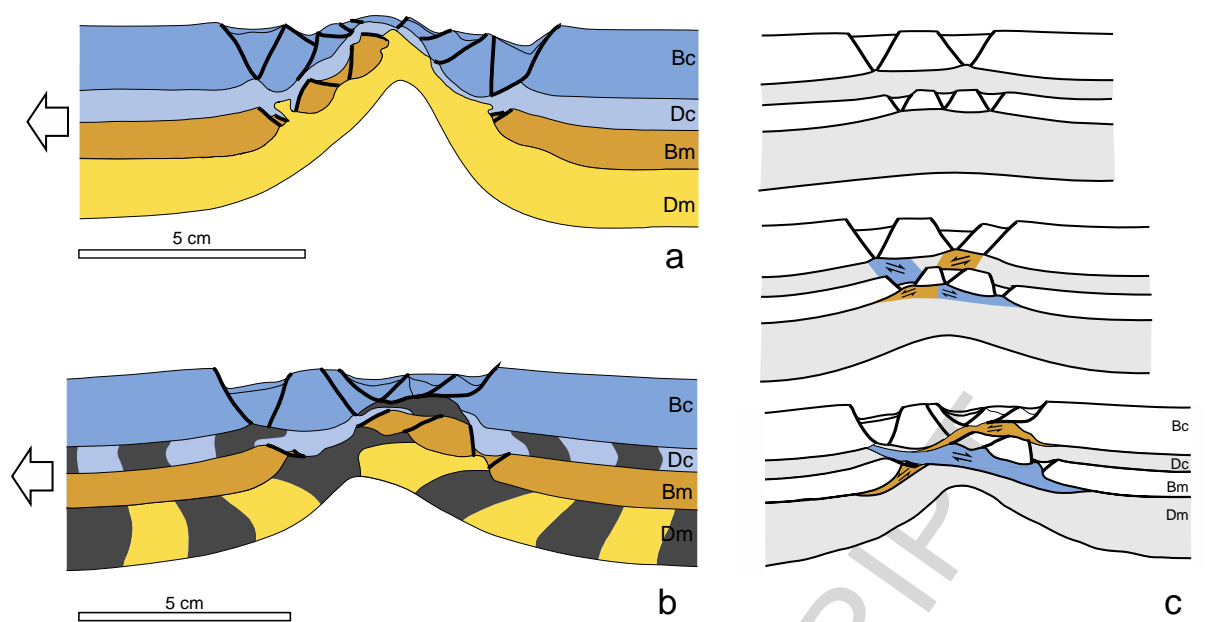

C

Fig.16. Analogue models of rifting in a four-layer brittle-ductile lithosphere (modified after Brun and Beslier, 1996). Bc: Brittle crust; Dc: Ductile crust; Bm: Brittle mantle; Dm: Ductile mantle. Arrows correspond to the applied boundary displacement. a) Model stretched up the exhumation of ductile mantle. b) Model with stretching amount lower than for model-a (vertical passive markers show the sense of shear in the ductile layers). c) Restoration of model-b showing the conjugate pattern of shear zones in ductile crust and mantle. 


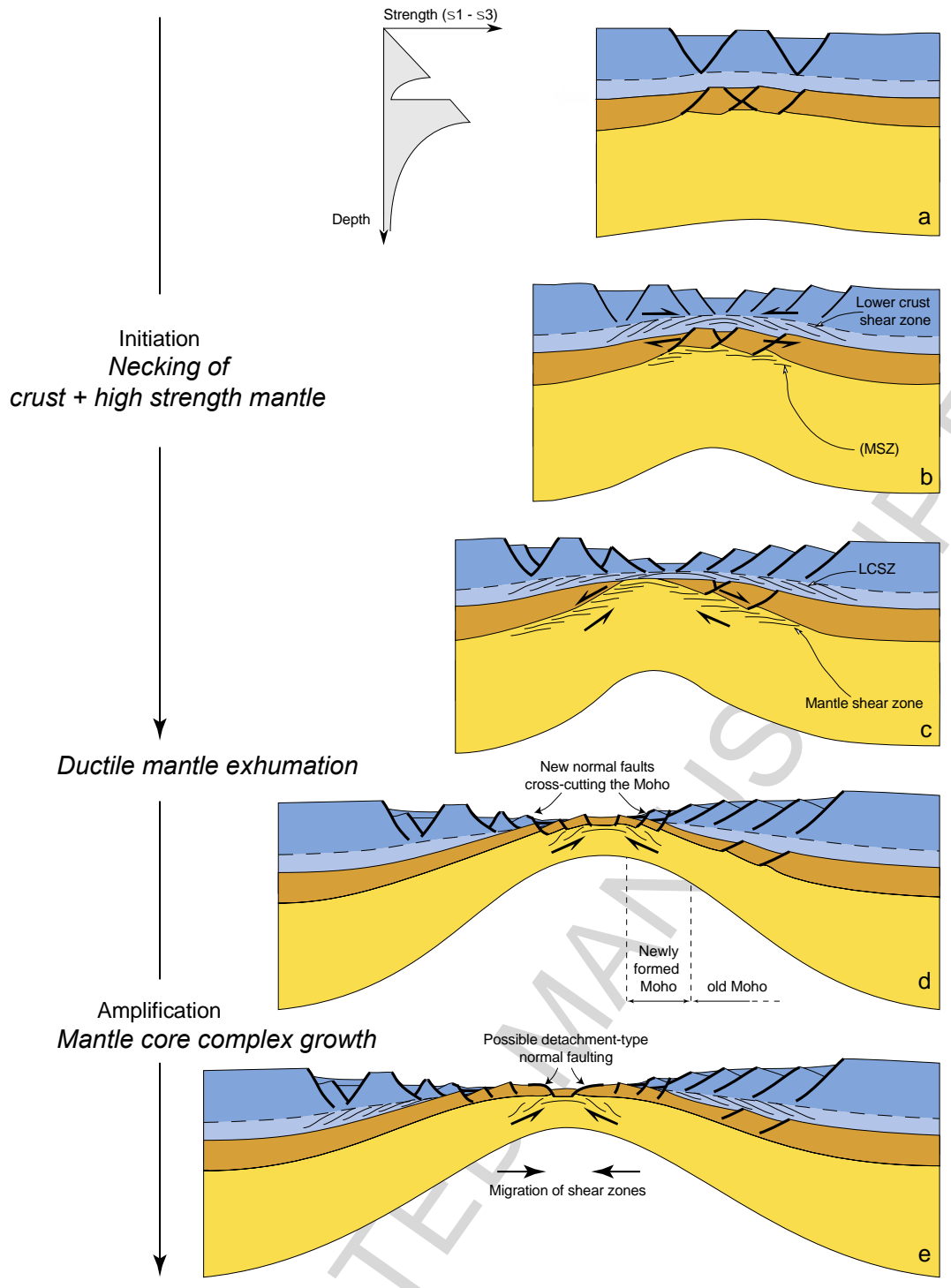

Fig.17. General deformation model deduced from analogue model (modified from Brun and Beslier, 1996). The evolution shows two main stages: i) "Initiation" corresponding to the necking of the whole crust plus high-strength mantle and ii) the "amplification" corresponding to the exhumation of mantle until volcanic crust is created. The initiation stage ends when the ductile continental mantle reaches the surface. During the amplification stage the exhumation of mantle could likely occur through successive rolling hinge detachment faults as observed in ultra-slow spreading ridges (Fig. 15b). The ductile crust shear zones (LCSZ) correspond to décollements (i.e. layer-parallel shear) between the upper brittle crust and the high strength sub-Moho mantle in which strain intensity increases toward the rift axis. As the mantle shear zones (MSZ), which accommodate mantle ascent and exhumation since the initiation, continuously migrate toward the rift axis (b to e) there is no permanent detachment fault at mantle level. 


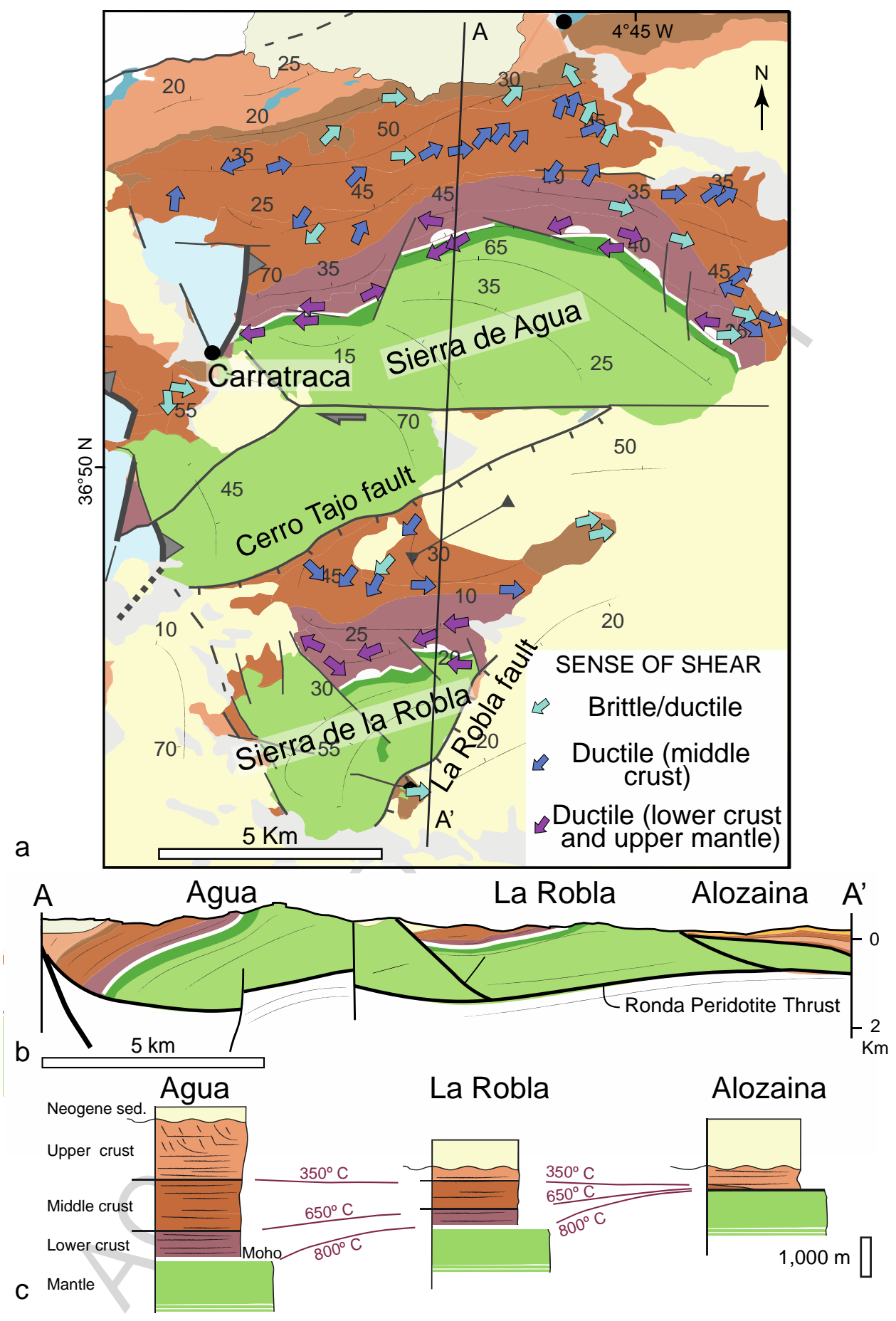

Fig.18. Brittle and ductile deformation pattern at the tip of a passive margin (Carratraca sector of the Ronda peridotite massif; Western Betics; South Spain) (modified after Frasca et al., 2016). a) Geological map showing the senses of shear in the brittle/ductile crust and ductile crust and mantle. b) NS-trending cross-section (see location in a) showing the three tilted blocks of Agua, La Robla and Alozaina. c) Variation of the ductile crust thickness from Agua to Alozaina. 

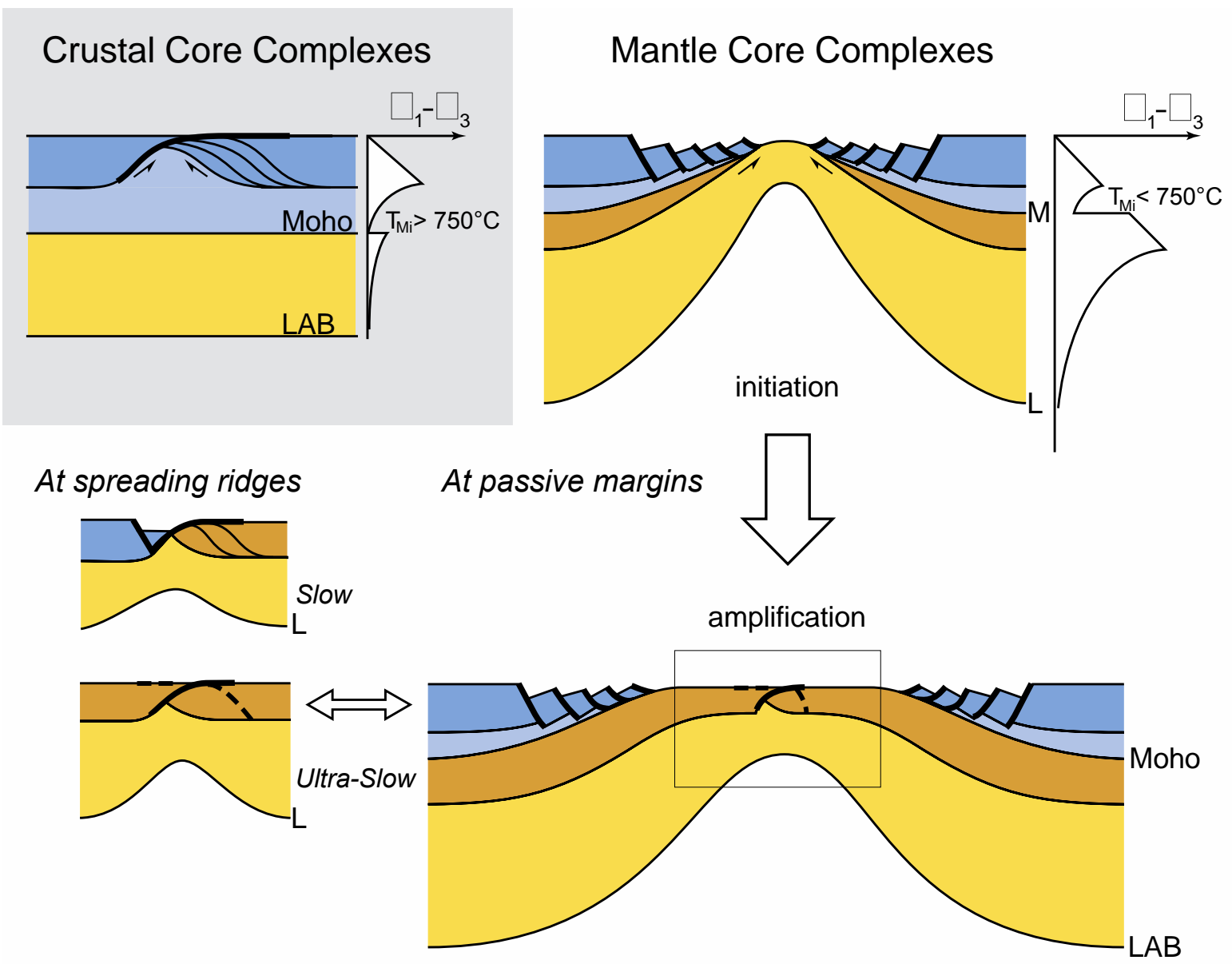

Fig.19. Diagram summarizing similarities and differences, in terms of geometry, structures and rheology, between the three types of extensional structures in which the ductile crust or mantle is exhumed. 
Table 1

\begin{tabular}{|c|c|c|c|c|}
\hline Reference & $\begin{array}{l}\text { Applied } \\
\text { displacements }\end{array}$ & $\begin{array}{l}\text { Localizing } \\
\text { perturbation }\end{array}$ & $\begin{array}{l}\text { Strain } \\
\text { softening }\end{array}$ & $\begin{array}{l}\text { Modeling } \\
\text { method }\end{array}$ \\
\hline \multicolumn{5}{|c|}{ Type of model : Brittle-ductile two-layer system } \\
\hline Wdowinski \& Axen 1992 & Asymmetrical & Rigid hanging wall & & Numerical \\
\hline Brun et al 1994 & Asymmetrical & Local low viscosity & & Analogue \\
\hline Lavier et al $1999 ; 2000$ & Symmetrical & Local cohesion loss & $\mathrm{x}$ & Numerical \\
\hline Skelton \& Koyi 2001 & Asymmetrical & Fault & & Analogue \\
\hline Lavier \& Buck 2002 & Symmetrical & Local cohesion loss & $\mathrm{x}$ & Numerical \\
\hline Wijns et al 2005 & Asymmetrical & None & $x$ & Numerical \\
\hline Gessner et al 2007 & Asymmetrical & None & $\mathrm{x}$ & Numerical \\
\hline Tirel et al 2006 & Asymmetrical & Local low viscosity & & Analogue \\
\hline Mezri et al 2015 & Symmetrical & Thermal/Lower crust & $\mathrm{x}$ & Numerical \\
\hline Kydonakis et al 2015 & Asymmetrical & Wedge shape crust & & Analogue \\
\hline \multicolumn{5}{|c|}{ Type of model : Lithosphere-scale } \\
\hline Tirel et al 2004; 2008 & Asymmetrical & Local low viscosity & & Numerical \\
\hline Tirel et al 2009 & Asymmetrical & None & $\mathrm{x}$ & Numerical \\
\hline Rey et al 2009a \&b & Symmetrical & Fault and point-like & $\mathrm{x}$ & Numerical \\
\hline Huet et al 2011 & Asymmetrical & Local higher cohesion & & Numerical \\
\hline Wang et al 2015 & Asymmetrical & Local low viscosity & $\mathrm{x}$ & Numerical \\
\hline Schenker et al 2012 & Symmetrical & Thermal/Mantle & $\mathrm{x}$ & Numerical \\
\hline Wu et al 2015 & Symmetrical & Wedge shape crust & $\mathrm{x}$ & Numerical \\
\hline Wu \& Lavier 2015 & Symmetrical & Wedge shape crust & $\mathrm{x}$ & Numerical \\
\hline
\end{tabular}


Table 2

\begin{tabular}{|l|l|l|}
\hline Reference & Method & Particular focus \\
\hline \multicolumn{2}{|l|}{ Rifting process : Symmetrical or nearly symmetrical } & \\
\hline Brun and Beslier 1996 & Analogue & \\
\hline Nagel and Buck 2004, 2007 & Numerical & \\
\hline Lavier and Manatschal 2006 & Numerical & Role of gravitational instabilities, \\
\hline Burov 2007b & Numerical & \\
\hline Weinberg et al 2007 & Numerical & Lithosphere mantle counter flow \\
\hline Beaumont and Ings 2012 & Numerical & \\
\hline Nestola et al 2013, 2014 & Analogue & \\
\hline Rifting process : Dominantly or fully asymmetrical & Crustal thickness variation \\
\hline Harry \& Grandell 2007 & Numerical & Stretching rate \& strain softening \\
\hline Huismans \& Beaumont 2007 & Numerical & Strain softening \\
\hline Brune et al 2014, 2016 & Numerical & Mechanical anisotropy \\
\hline Duretz et al 2016 & Numerical & \\
\hline
\end{tabular}




\section{Highlights}

Review of the mechanisms of crust and mantle exhumation in core complex-type extension

Analogue and numerical modeling support the rolling hinge process for core complex development

Large-scale detachments do not form at the onset of deformation but during progressive extension. 